\title{
CIÊNCIAS SOCIAIS APLICADAS: \\ CONTEXTUALIZANDO E COMPREENDENDO \\ AS NECESSIDADES SOCIAIS
}

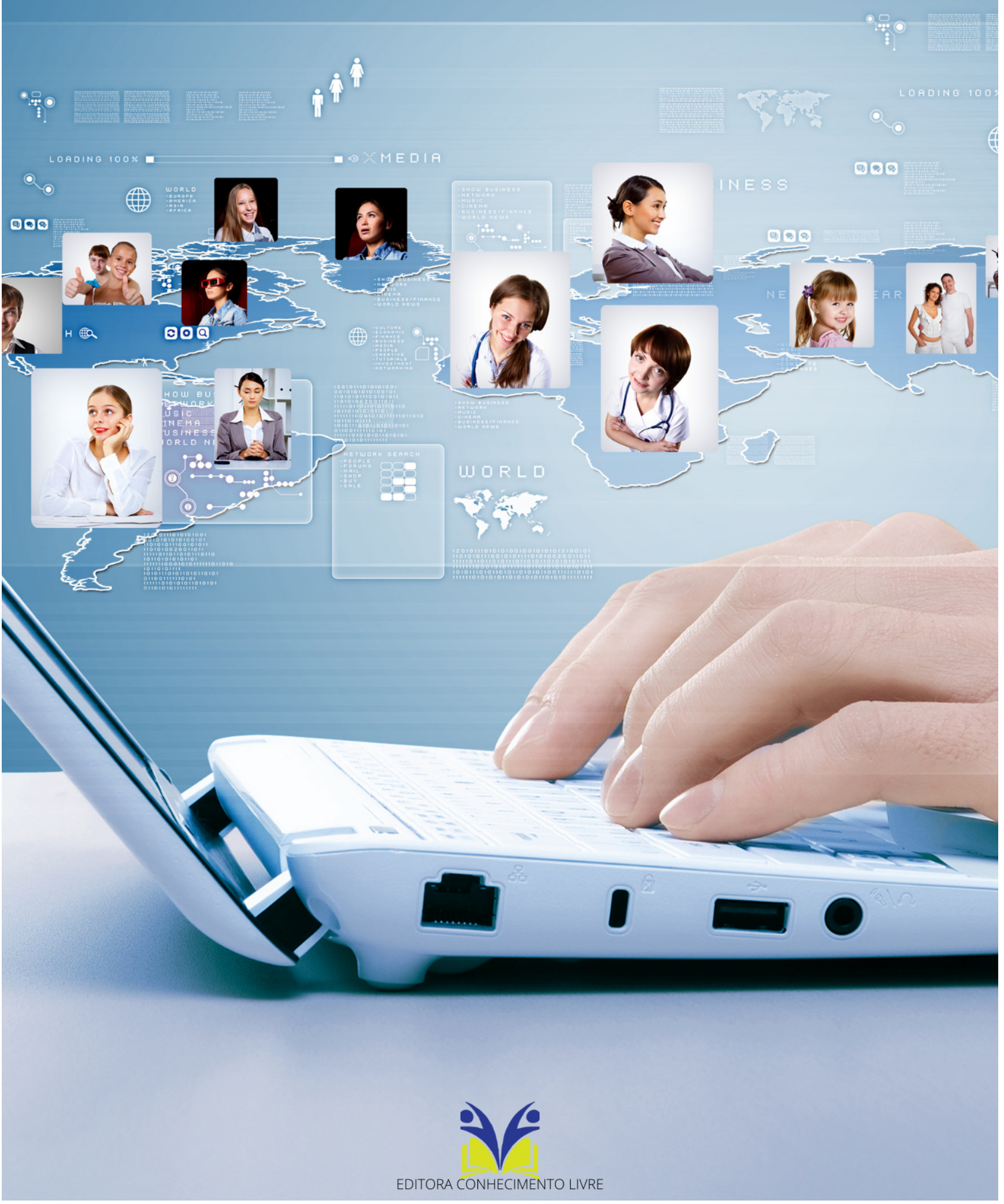


Frederico Celestino Barbosa

Ciências sociais aplicadas: contextualizando e compreendendo as necessidades sociais

$1^{\text {a }}$ ed.

Piracanjuba-GO

Editora Conhecimento Livre

Piracanjuba-GO 
$1^{\mathrm{a}} \mathrm{ed}$

\section{Dados Internacionais de Catalogação na Publicação (CIP)}

\section{Barbosa, Frederico Celestino}

B238C Ciências sociais aplicadas: contextualizando e compreendendo as necessidades sociais

/ Frederico Celestino Barbosa. - Piracanjuba-GO

Editora Conhecimento Livre, 2021

149 f.: il

DOI: $10.37423 / 2021$. edcl394

ISBN: 978-65-5367-038-9

Modo de acesso: World Wide Web

Incluir Bibliografia

1. atualidade 2. relacionamento 3. soluções I. Barbosa, Frederico Celestino II. Título

CDU: 300

https://doi.org/10.37423/2021.edc1394

O conteúdo dos artigos e sua correção ortográfica são de responsabilidade exclusiva dos seus respectivos autores. 


\title{
EDITORA CONHECIMENTO LIVRE
}

\section{Corpo Editorial}

\author{
Dr. João Luís Ribeiro Ulhôa \\ Dra. Eyde Cristianne Saraiva-Bonatto \\ MSc. Frederico Celestino Barbosa \\ MSc. Carlos Eduardo de Oliveira Gontijo \\ MSc. Plínio Ferreira Pires
}




\section{SUMÁRIO}

CAPÍTULO 1 5

MULTIPARENTALIDADE E SEUS EFEITOS SUCESSÓRIOS

Aryelle Gomes Oliveira

DOI 10.37423/211205145

CAPÍTULO 2

A EFETIVAÇÃO DA PENHORA NO PROCESSO CIVIL À LUZ DO PRINCÍPIO DA DIGNIDADE

DA PESSOA HUMANA E GARANTIA DO MÍNIMO EXISTENCIAL

EMILLY AQUINIS GOMES E GOUVEIA

DOI 10.37423/211205155

CAPÍTULO 3 52

COMO AS FAZENDAS COM PEQUENA ESCALA DE PRODUÇÃO UTILIZAM OS MÉTODOS DE INOVAÇÕES?

José Francisco dos Reis Neto

Marlucy Ferreira Machado

Wesley Osvaldo Pradella Rodrigues

Ismael da Silva

DOI 10.37423/211205158

CAPÍTULO 4

QUATRO DIAS DE REBELIÃO, COVID-19 E VACINAÇÃO:DO FICCIONAL AO FATUAL

Sueli Meira Liebig

DOI 10.37423/220105192

CAPÍTULO 5

UTILIZAÇÃO DA RESERVA PARA CONTINGÊNCIAS: UMA ANÁLISE DAS EMPRESAS DE

CAPITAL ABERTO

Jefferson Alex Santos e Silva

Ítalo Almeida Andrade

Thamires Pereira Lopes

Marcos Vinicios Ferreira dos Santos

Gilmar Neris Teixeira

Wagner de Paulo Santiago

DOI 10.37423/220105195

CAPÍTULO 6

OS PRINCIPAIS IMPACTOS DA MEDIDA PROVISÓRIA 881/19 NO DIREITO EMPRESARIAL José Mendes Pereira Neto

DOI 10.37423/220105197 
ENTRE A CRUZ E A ESPADA: A POPULAÇÃO LGBTQI+ E AS ELEIÇÕES DE 2018

Paulo de Tarso Xavier Sousa Junior

Brenna Galtierrez Fortes Pessoa

João Caio Silva Castro Ferreira

Elaine Ferreira do Nascimento

Liana Maria Ibiapina do Monte

Giorge André Lando

Marcos Renato de Oliveira

DOI 10.37423/220105199 


\section{Capítulo 1}

\section{doi $10.37423 / 211205145$}

\section{MULTIPARENTALIDADE E SEUS EFEITOS SUCESSÓRIOS}
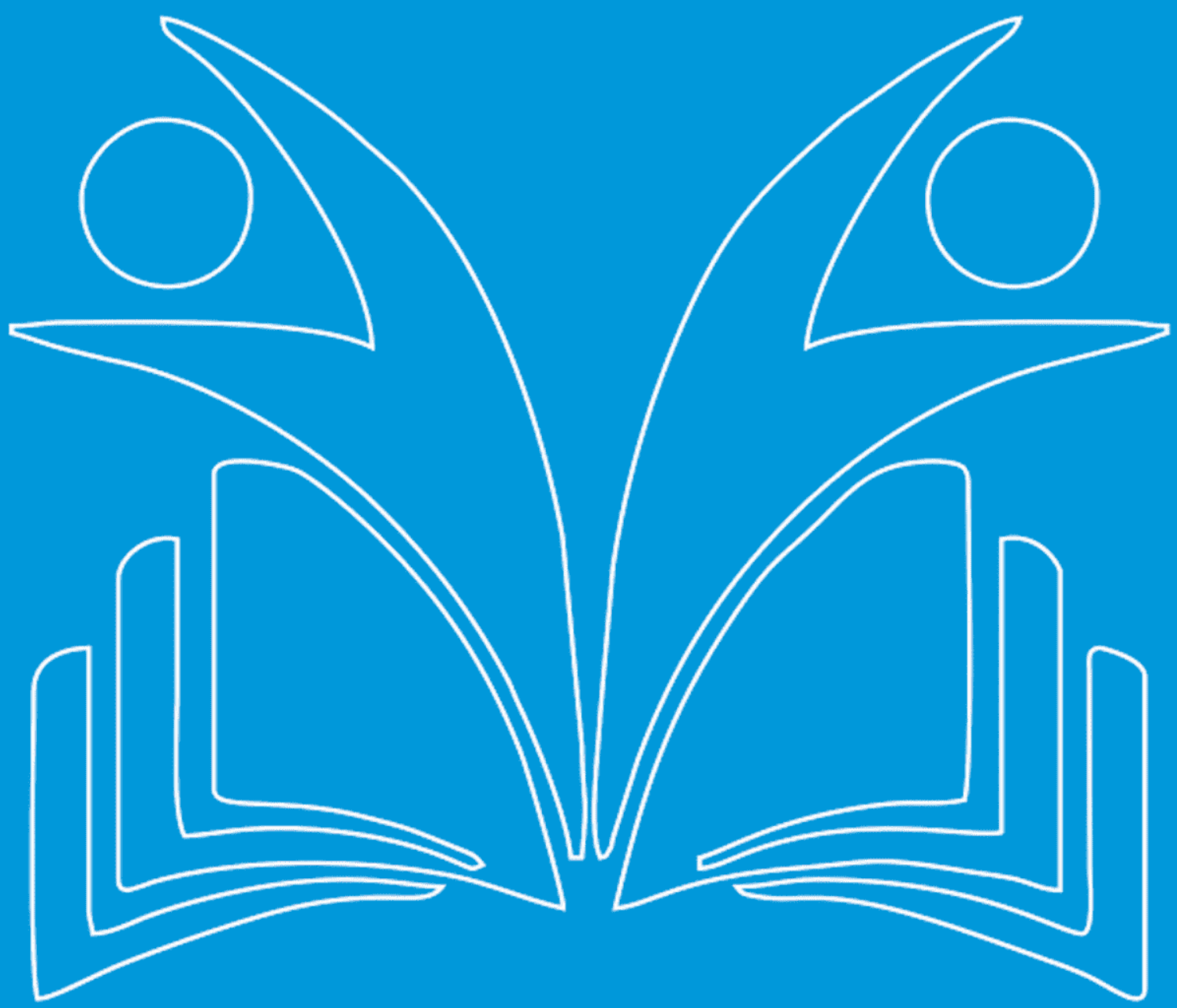
Resumo: O direito de família vem evoluindo nos últimos anos, frente aos novos conceitos de família da sociedade contemporânea. Assim, o presente artigo debruçar-se-á sobre normas constitucionais e extras constitucionais que disciplinam a matéria para melhor compreender os princípios norteadores de tal instituto, seus conceitos, e sua correlação com o direito sucessório. Ultrapassada tal pesquisa legislativa, verificar-se-á a aplicabilidade destes princípios e normas no ordenamento jurídico moderno, buscando analisar decisões judiciais proferidas pelos tribunais pátrios afim de identificar como o conceito de multiparentalidade vem influenciando o direito sucessório. Buscando assim identificar quais os efeitos da multiparentalidade no ordenamento jurídico brasileiro e no direito sucessório? Tudo isto, partindo da hipótese da possibilidade do direito de sucessão em herança de membro familiar sócio afetivo no intuito de identificar se há alguma discrepância entre herdeiros afetivos e herdeiros legítimos/biológicos. Conforme se verá mais adiante, o presente artigo busca em sua essência analisar os efeitos da multiparentalidade no direito sucessório, isso porque tal fenômeno da sociedade contemporânea implica em sérias mudanças no rol de herdeiros de um espólio, fenômeno este que tem guarida na moderna concepção jurídica de que laços afetivos geram obrigações e criam direitos tanto quanto laços biológicos.

Palavras-chave: Direito Civil. Filiação. Socioafetiva. Multiparentalidade. Sucessório. 


\section{INTRODUÇÃO}

O afeto é o laço mais espontâneo da relação, tanto entre pais e filhos, como entre a esposa e o marido por exemplo. O modelo tradicional da família passou a ser desconstituído com as mudanças sociais, oferecendo uma nova visão para a construção familiar, sendo ele o afeto, obtendo destaque no Direito de Famílias. Conforme foram ocorrendo às mudanças na sociedade, as famílias também passaram por estas, pois o direito não poderia se manter inerte.

Por este motivo, o presente artigo tem como tema a multiparentalidade e seus efeitos sucessórios. A partir do referido tema, à problemática que traz o seguinte questionamento: Quais os efeitos da multiparentalidade no direito sucessório brasileiro? Em observação aos novos modelos familiares, a duplicidade de genitores, faz com que os infantes sejam protegidos para que na falta de um destes façam parte da partilha da herança. A boa convivência deve ser analisada para que se possa conseguir incluir no registro o pai ou a mãe afetiva, além da biológica.

Os objetivos específicos do presente artigo visam verificar os princípios norteadores do direito de família traçados na Carta Magna; com propósito de enfatizar a importância de um ambiente familiar em que o menor se sinta confortável; demonstrando por fim que a lei pátria não traça distinções e de igual forma busca promover e preservar todos os tipos atuais de família existentes na sociedade contemporânea, desde que cercado de laços de afeto entre os seus integrantes, cuidado, amor e carinho; e, inclusive, demonstrando que a legislação busca também proteger a igualdade entre os filhos biológicos ou afetivos, assim como o inverso, ou seja, paternidade e maternidade socioafetiva.

A família deve ser o lugar de construção dos valores do ser humano, como o respeito, dignidade, e principalmente o local onde se deve ter o principal que é o afeto para que os laços construídos sejam mantidos por muito tempo, por este motivo principal para o desenvolvimento da presente pesquisa como justificava social além de jurídica para o estudo da temática proposta, trazendo casos reais, e aparato bibliográfico sobre o assunto a ser discutido como justificativa acadêmica.

O presente artigo utilizou-se da metodologia científico-jurídica analítica, buscando em um primeiro momento analisar as normas constitucionais e extra constitucionais que disciplinem as questões relativas ao direito de família e sucessões, como meio de criar uma base jurídica sólida, que permita compreender os desdobramentos destes atos normativos em virtude da evolução sociológica do conceito de família. E só então, através da análise de julgados, verificar como as cortes nacionais vem 
decidindo acerca da questão da multiparentalidade no direito sucessório e quais as implicações destas decisões no ordenamento jurídico brasileiro.

Como provável resposta a esta discussão sobre o direito sucessório quando se trata da multiparentalidade, de que os filhos vindos de que qualquer que seja o meio desde que seja legal, e que esteja no registro, esteja em concorrência com os demais filhos, prevalecendo a isonomia entre eles, pois, se pode ter a duplicidade materna ou paterna, deverá continuar para a partilha de herança.

\section{DIREITO DE FAMÍLIA NO ÂMBITO CONSTITUCIONAL}

O conceito de família vem se modificando ao longo do tempo. O atual conceito de família é mais amplo, pois antigamente somente o homem detinha do poder familiar, que se adquire a partir do casamento. O afeto não era importante, somente se dava pelo contrato, mesmo que faltassem sentimentos.

Para Carlos Roberto Gonçalves (2017), entende o conceito de família como uma realidade sociológica que faz parte da manutenção do Estado. Sendo a família núcleo fundamental para repousar a organização social. Trata que o termo família abrange todas as pessoas que tenham um vínculo em comum, tanto sanguíneo, como o afetivo. A família é o primeiro local onde o ser humano passa a se socializar.

Logo Maria Berenice Dias (2017, p.49) trata da família como:

A família é cantada e decantada como a base da sociedade e, por essa razão, recebe especial proteção do Estado (CF 226). A própria Declaração Universal dos Direitos do Homem estabelece (XVI 3): A família é o núcleo natural e fundamental da sociedade e tem direito à proteção da sociedade e do Estado.

Nesse sentido, a família por ser a base de formação da sociedade, deve o Estado protegê-la, mesmo que venha de diferentes arranjos. No mais, Silvio de Salvo Venosa $(2017$, p. 19) trata das mudanças na sociedade:

\footnotetext{
A sociedade de mentalidade urbanizada, embora não necessariamente urbana cada vez mais globalizada pelos meios de comunicação, pressupõe e define uma modalidade conceitual de família bastante distante daquela regulada pelo Código de 1916 e das civilizações do passado.
}

Em seu conceito de família, como a sua forma de compreensão, encontra-se em mutabilidade dentro da sociedade. Em tempos antigos, o conceito de família era o modelo que se encontrava pautado no contrato que vinculava o casamento. No Brasil, a partir da Constituição de 1988, foi o maior marco divisório de águas no direito privado, ao tratar das normas do direito de família. A união estável passou 
a ser reconhecida como entidade familiar desde 2011, conforme pode ser observado no art. $226, \S 7^{\circ}$ da Constituição Federal.

As novas entidades familiares passam a ser constituídas não somente por laços sanguíneos, bem como pela valoração do afeto. Tendo em vista Pereira (2017, p.21) "não são poucas nem infrequentes as modificações que o Direito de Família suporta em consequência das mutações conceituais dos tempos modernos, algumas com impacto profundo sobre os institutos tradicionais."

O fato do direito de família, estabelecer novos modelos familiares, diferente do modelo que era dado como tradicional (entre homem e mulher) faz com que a conceituação passe a ser diferente, tendo em vista que deve abranger toda a diversidade, que se encontra no núcleo familiar. Com a mutação, que surgiu através dos tempos, a prática da adoção passou a ser cada vez mais presente na sociedade brasileira. Passando a constituir um núcleo familiar ainda mais amplo. No próximo tópico serão abordados os artigos 226 e 227 da Constituição Federal.

Os princípios norteadores das relações familiares são eles: princípio da dignidade da pessoa humana ( art. $1^{\circ}$, III, da Constituição Federal), da solidariedade familiar, ( $\operatorname{art.} 3^{\circ}, \mathrm{l}$, da Constituição Federal), da equiparação dos filhos e da vedação de designações discriminatórias relativas à filiação (art. $227, \S 6^{\circ}$ da Constituição Federal), do melhor interesse da criança e do adolescente e da proteção integral( art. $3^{\circ}$ do Decreto $n^{\circ}$ 99.710/ 1990), da prioridade absoluta, da afetividade e do cuidado (princípios constitucionais implícitos (art. $5^{\circ}, \S 2$ 을 da Constituição Federal de 1988).

A dignidade da pessoa humana deve ser observada de acordo com sua realidade. O princípio do respeito à dignidade da pessoa humana constitui, como base da comunidade familiar, garantindo o desenvolvimento e a realização de todos os seus membros, principalmente da criança e do adolescente (CF, art. 227).

O princípio da solidariedade familiar encontra-se previsto no art. 3ํ, inciso I, da Constituição Federal, conhecido como objetivo de construir uma sociedade livre, justa e solidária. A solidariedade deve se fizer presente nas relações familiares.

Ser solidário significa que irá responder pelo outro. Remetendo ideia ao direito das obrigações quando se trata da solidariedade. O princípio da afetividade, é princípio que estabiliza as relações socioafetivas, e na comunhão de vida, com primazia para que se possa considerar as relações patrimoniais ou de caráter biológico. 
Todo ser humano desde a infância necessita do afeto para que passe a se tornar um ser integral. 0 afeto não somente envolve os integrantes de uma família, como também coloca humanidade em cada uma delas. Dias (2017, p. 85) trata do princípio da afetividade como: “O princípio jurídico da afetividade faz despontar a igualdade entre irmãos biológicos e adotivos e o respeito a seus direitos fundamentais. O sentimento de solidariedade recíproca não pode ser perturbado pela preponderância de interesses patrimoniais".

O princípio do melhor interesse da criança e do adolescente está no art. 227 da Constituição Federal, em seu caput, que significa que a criança, fazendo a inclusão do adolescente, deverá ter seus interesses tratados como prioridade pelo Estado, pela família e também pela sociedade, nos direitos em que Ihes dizem respeito. Para que seja possível fazer a aplicação do princípio jurídico, deve ser necessário fazer a consideração por base legal e constitucional. Lôbo $(2017$, p.78) faz a abrangência ao idoso:

A Constituição ampliou sua abrangência, para alcançar outros familiares, notadamente o jovem e o idoso. A EC n. 65 alterou a redação do art. 227 da Constituição para incluir o jovem, para além da criança e do adolescente, como titular dos direitos fundamentais ali consagrados, dentre eles o direito à convivência familiar.

O princípio da prioridade absoluta se encontra presente no art. 227 da Constituição Federal de 1988, e também está no art. 4ㅇ do Estatuto da Criança e do Adolescente e no art. 3o do Estatuto do Idoso.

A prioridade absoluta tem papel importante, pois trata da primazia dos direitos da criança e do adolescente, no que envolve os mesmos, tanto nas esferas, extrajudicial, judicial, administrativa, familiar ou social. No art. 227, da Constituição Federal, conforme Pereira (2017, p.89) "família se responsabilize pela manutenção da integridade física e psíquica, a sociedade pela convivência coletiva harmônica, e o Estado pelo constante incentivo à criação de políticas públicas".

Logo no Estatuto da Criança e do Adolescente, traz quase que de forma igual o art. 227 da Constituição Federal, diferenciando o parágrafo único, que garante prioridade de atendimento em qualquer circunstância, primazia de atendimento ou serviços públicos, prioridade na formulação e execução das políticas sociais públicas.

O cuidado inicialmente se deu pela palavra latina cura, que significa atenção, interesse e cuidado. 0 princípio do cuidado nas relações familiares, ao reconhecer as entidades familiares formadas por dois pais e seus descendentes conforme o art. 226, da Constituição Federal, § 40 - “Art. 226. A família, base 
da sociedade, tem especial proteção do Estado. [...]§ 4으 Entende-se, também, como entidade familiar a comunidade formada por qualquer dos pais e seus descendentes.

No Código Civil de 2002, é possível notar a influência do princípio citado anteriormente em sua essência. $O$ direito de que o indivíduo passe a receber alimentos está pautado no princípio constitucional da dignidade da pessoa humana. E também faz inserção do companheiro como herdeiro necessário. A "proteção da pessoa dos filhos" faz referência ao valor do cuidado.

\subsection{NOÇÕES SOBRE FILIAÇÃO E PARENTALIDADE NO DIREITO CIVIL}

Para Pereira (2017, p. 239) a "filiação é a relação de parentesco, que é estabelecido entre duas pessoas qual é o titular de autoridade parental e a outra vincula pelo fator biológico ou socioafetivo". Quando vinculada ao homem é chamada de paternidade e a mulher de maternidade. A filiação surge do latim filiatio, que significa procedência, laço de parentesco dos pais com os filhos, enlace, dependência. Lôbo (2017, p.239), sobre a filiação aduz que:

Desde a Constituição de 1988 não há mais filiação legítima, ou filiação ilegítima, ou filiação natural, ou filiação adotiva, ou filiação incestuosa, ou filiação matrimonial ou extramatrimonial, ou filiação adulterina, como o direito anterior as classificava.

O art. 1596 do Código Civil trata que os filhos de origem não biológica e biológica, são detentores de direitos de forma igualitária, sendo vedado qualquer tipo de discriminação. São iguais os filhos de origem biológica e os socioafetivos. Para aferir a socioafetividade deve ser observada a convivência familiar e a consolidação do estado de filiação. No mais, tempo e aparência são fundamentais, mas cada caso deve ser observado de forma individual, pois a lei não determina o tempo de convivência.

Os pais são livres para planejar a forma da filiação que irão aderir qual a quantidade de filhos, o Estado não inserir nenhum tipo de limitação. Podendo os filhos ser de origem biológica conhecida ou desconhecida. A Constituição de 1988, em seu art. 226, § 7o, embasada no princípio da dignidade da pessoa humana e da paternidade responsável, o planejamento é de livre opção do casal.

Podendo, não ser de um casal, mas de qualquer um dos pais, já que a entidade familiar monoparental é constituída por qualquer um dos pais com seus filhos, os deveres e responsabilidades dos pais provêm dos direitos dos filhos à igualdade. Maria Berenice Dias (2017, p.714) “Chamar de investigação de paternidade todas as demandas que procuram a identificação dos vínculos de filiação demonstra certo ranço cultural". Demonstrando que quando trata de investigação de paternidade, o juiz teria que agir como um detetive para descobrir quem é o pai daquela criança. 
O interesse para que reconhecesse os pais nunca foi uma preocupação do Estado. Em tempos antigos, os filhos que eram tidos fora do casamento sequer poderiam ser reconhecidos, mas já os que eram concebidos durante a constância do casamento presumiam-se serem filhos do cônjuge. Maria Berenice Dias (2017, p.715) “Em nome da preservação do núcleo familiar e da mantença da paz social, a lei prestigia a relação de paternidade por presunção legal (CC 1.597): o pai é o marido da mãe". Mas, na pater est irá manter a paternidade fictícia sobre a ver biológica.

No entanto Maria Berenice Dias (2017, p. 716) “Mas a jurisprudência tem ido além ao admitir que no registro conste o nome de dois pais ou duas mães: a filiação genética e a socioafetiva, o que passou a ser chamado de multiparentalidade." Passaram a dar mais importância para o critério afetivo, que é equiparado à origem biológica, pois tem grande importância. Somente terá que existir a verdade biológica quando estiverem ausentes os critérios que demonstrem a afetividade.

Rolf Madaleno (2018, p. 659) ao tratar do valor:

O real valor jurídico está na verdade afetiva e jamais sustentada na ascendência genética, porque essa, quando desligada do afeto e da convivência, apenas representa um efeito da natureza, quase sempre fruto de um indesejado acaso, obra de um indesejado descuido e da pronta rejeição.

A filiação consangüínea equipara-se a socioafetiva, pois faz com que a relação parental esteja completa. Lôbo (2017, p.25) "Pode-se afirmar que toda paternidade é necessariamente socioafetiva, podendo ter origem biológica ou não biológica; em outras palavras, a paternidade socioafetiva é gênero do qual são espécies a paternidade biológica e a paternidade não biológica.“

Conhecido popularmente como filho de criação, onde a adoção não foi realizada, mas a família passa a tratar como se fosse filho biológico. E no direito das famílias a presunção do afeto, já caracteriza a existência de que seja possível enxergar a filiação, por isso Lôbo (2017, p. 262):

O estado de filiação compreende um conjunto de circunstâncias que solidificam a presunção da existência de relação entre pais, ou pai e mãe e filho, capaz de suprir a ausência do registro do nascimento. Em outras palavras, a prova da filiação dá-se pela certidão do registro do nascimento ou pela situação de fato.

Para que seja solidificada a existência de laços entre os pais e filhos na ausência de serem consangüíneos, deverão ser observadas as relações familiares existentes entre os mesmos, fazendo com que o ponto principal seja o afeto mantido entre os filhos e pais. 


\section{DIREITO SUCESSÓRIO BRASILEIRO}

Neste tópico serão abordadas importantes questões ao tratar do direito sucessório, no que tange a questão do reconhecimento dos filhos, e quando se trata da sucessão decorrente da multiparentalidade. $\mathrm{O}$ direito sucessório se originou desde o momento em que o homem deixa de ser nômade e começou a construir seu patrimônio, passando a se constituir dentro da sociedade, onde a família passou a ter seu patrimônio e sua religião, denominada de culto familiar, e que era transmitida de pai para filho.

\subsection{CONCEITUAÇÃO E IMPORTÂNCIA DA SUCESSÃO}

No entanto, a sucessão deve ser vista de duas formas: subjetiva e objetiva. Pela forma subjetiva, é quando a pessoa adquire bens e obrigações do falecido, quanto ao objetivo, trata dos bens e obrigações gerais do falecido. Segundo $\operatorname{Nader}(2016$, p.33) ao tratar da sucessão; "O ato de suceder traz consigo não apenas a idéia de substituição, mas também de continuidade. As relações jurídicas preexistentes têm o seguimento de acordo com as peculiaridades anteriores à troca de titularidade.

Para Fábio Ulhoa Coelho ao fazer a definição do direito sucessório traz a informação de que ele tem aproximação com o direito das coisas, já que disciplina sobre direitos e obrigações deixados pelo de cujus. Sendo assim, conforme Coelho (2012, p. 494):

O direito das sucessões disciplina a destinação do patrimônio da pessoa física após sua morte. Melhor dizendo, contempla as normas que norteiam a superação de conflitos de interesses envolvendo a destinação do patrimônio de pessoa falecida. Sua matéria, portanto, é a transmissão causa mortis. [...].Como o patrimônio não pode ficar sem titular, morrendo esse, deve ser imediatamente transferido para outras pessoas. Por esse ângulo de abordagem, o direito das sucessões parece aproximar-se do direito das coisas.

O Código Civil Brasileiro utiliza-se da nomenclatura de 'Direito das coisas', como título de seu Livro III, tendo em vista que a maior parte da doutrina considera como 'direitos reais'. Flávio Tartuce traz a seguinte definição de direito das coisas (2017, p.16):

A expressão Direito das Coisas sempre gerou dúvidas do ponto de vista teórico e metodológico, principalmente quando confrontada com o termo Direitos Reais. Muito didaticamente, pode-se afirmar que o Direito das Coisas é o ramo do Direito Civil que tem como conteúdo relações jurídicas estabelecidas entre pessoas e coisas determinadas, ou mesmo determináveis.

No entanto, a coisa sempre será algo de cunho econômico e que sejam corpóreos, já os bens podem ou não ter seu conteúdo econômico. Logo o termo 'direito das coisas' abordaria mais conteúdo do 
que os 'direitos reais', o que aborda a posse, não se encontra nos direitos reais previstos no Código Civil.

Ao tratar da teoria realista ou clássica, existiria uma relação entre a pessoa e a coisa, gerando uma relação de domínio sem nomenclatura. Assim conceitua Flávio Tartuce (2017, p. 18)“Assim, o direito real opõe-se ao direito pessoal, pois o último traz uma relação pessoa- pessoa, exigindo-se determinados comportamentos"

Ao tratar da habitação, Maria Helena Diniz (2014, p. 492) conceitua da seguinte forma: "Segundo os arts. 1.225, VI, e 1.414 do Código Civil é a habitação o direito real temporário de ocupar gratuitamente casa alheia, para morada do titular e de sua família".

As partes da habitação são o proprietário que transmite o objeto e o habitante, que poderá usufruir da moradia de forma gratuita. Foi reconhecido pelo art. 1.831 do Código Civil, o direito real de habitação ao cônjuge sobrevivente, independente do regime de casamento, desde que aquele fosse à residência da família. Flávio Tartuce, ao citar as novas famílias trata da seguinte forma (2017, p. 262):

No que toca à constituição de nova família, vislumbra-se a hipótese em que o cônjuge habitante não tem boas condições financeiras, ao contrário dos outros herdeiros, descendentes, que são inclusive proprietários de outros imóveis. Seria justo desalojar o cônjuge pelo simples fato de constituir nova família? Este autor entende que não, ponderando-se a favor da moradia e da família.

Ao fazer menção a união estável, pode ser analisada o artigo 6o da Constituição Federal, mas por analogia deve ser aplicado o art. 1.831 do Código Civil, e também se deve ter em vista o artigo $7^{\circ}$ da Lei 9.278/ 1996, ao tratar da união estável:

Dissolvida a união estável por rescisão, a assistência material prevista nesta Lei será prestada por um dos conviventes ao que dela necessitar, a título de alimentos, Parágrafo único. Dissolvida a união estável por morte de um dos conviventes, o sobrevivente terá direito real de habitação, enquanto viver ou não constituir nova união ou casamento, relativamente ao imóvel destinado à residência da família.

Quando um dos cônjuges necessitarem, poderão ser prestados os alimentos, e no caso da dissolução da união estável por morte, o cônjuge que sobreviver terá o direito à habitação, apenas enquanto não estiver mantendo relação com outra pessoa.

\subsection{HERANÇA E PROCEDIMENTOS}

Este capítulo conterá as explicações pertinentes à herança e seus procedimentos, para que possa compreender a questão dos filhos e dos cônjuges. As regras específicas da administração da herança 
estão nos artigos 1.791 e 1.797 do Código Civil, ao tratar da cessão estão nos artigos 1.793 a 1.795, e as regras do inventário no art. 1.796 do Código Civil. Quando o autor da herança falece, forma uma massa patrimonial, tendo em vista o Princípio da Saisine, passando aos herdeiros, mesmo que ainda não saibam que são os sucessores.

O Código Civil preceitua sobre a herança da seguinte forma, em seu artigo 1.791:

Art. 1.791. A herança defere-se como um todo unitário, ainda que vários sejam os herdeiros. Parágrafo único. Até a partilha, o direito dos co-herdeiros, quanto à propriedade e posse da herança, será indivisível, e regular-se-á pelas normas relativas ao condomínio.

Deste modo, com a abertura da sucessão, têm a transferência da titularidade da massa patrimonial, colocada como 'todo unitário', independente da aceitação. Pablo Stolze ao citar sobre a titularidade da herança, diz o seguinte (2017, p.2168):

Se é certo que a titularidade é de todos os herdeiros, que recebem a herança como um direito indivisível, em regime regulado pelas regras do condomínio, também é lógico que a alguém deve ser atribuída a responsabilidade pela direção do patrimônio, até a sua final individualização por cada um dos herdeiros.

No art. 1.793 do Código Civil, fazem com que haja a possibilidade de que a sucessão possa ser de forma aberta, e o quinhão pertencente ao co-herdeiro, possa ser objeto de cessão por escritura pública. Ao tratar do art. 1.794 do Código Civil, o co-herdeiro não poderá passar sua quota para pessoa estranha à sucessão. Caso o co-herdeiro tenha preferido este direito, terá que depositar o preço da quota cedida ao estranho.

O prazo de abertura da sucessão era de 30 dias, conforme o artigo 1.796 do Código Civil, mas por força do artigo 611 do Código de Processo Civil, o prazo passou a ser de 02 meses, para que designam inventariante para administrar os bens deixados pelo espólio, com seus débitos e créditos, até que seja entregue para o herdeiro definitivo.

A partir da realidade, deve ser observado o artigo 1.797 do Código Civil, sobre a previsão:

Art. 1.797. Até o compromisso do inventariante, a administração da herança caberá, sucessivamente:

I - ao cônjuge ou companheiro, se com o outro convivia ao tempo da abertura da sucessão;

II - ao herdeiro que estiver na posse e administração dos bens, e, se houver mais de um nessas condições, ao mais velho;

III - ao testamenteiro; 
IV - a pessoa de confiança do juiz, na falta ou escusa das indicadas nos incisos antecedentes, ou quando tiverem de ser afastadas por motivo grave levado ao conhecimento do juiz.

O compromisso do inventariante, a administração da herança poderá ter um administrador provisório ou ad hoc, a ordem a ser seguida deve ser conforme os incisos do presente artigo citado anteriormente.

Como herdeiros são os seguintes, segundo Fábio Ulhoa (2014,p. 140): “Herdeiro necessário (legitimário ou reservatário) é o descendente (filho, neto, bisneto etc.) ou ascendente (pai, avô, bisavô etc.) sucessível, ou seja, é todo parente em linha reta não excluído da sucessão por indignidade ou deserdação, bem como o cônjuge (CC, art. 1.845)."

No artigo 1.846 do Código Civil dispõe que: "Pertence aos herdeiros necessários, de pleno direito, a metade dos bens da herança, constituindo a legítima." Perante o artigo 1.799 do Código Civil a tratar da sucessão testamentária poderão ser chamados para suceder:

Art. 1.799. Na sucessão testamentária podem ainda ser chamados a suceder:

I - os filhos, ainda não concebidos, de pessoas indicadas pelo testador, desde que vivas estas ao abrir-se a sucessão;

II - as pessoas jurídicas;

III - as pessoas jurídicas, cuja organização for determinada pelo testador sob a forma de fundação.

No inciso I, podem ser chamados os filhos ainda não concebidos, de pessoas indicadas pelo testador, desde que vivas ao abrir a sucessão. Os filhos são os verdadeiramente privilegiados. A atual Constituição Federal em seu artigo 227, §6으, trata que não deve haver distinção entre os filhos, no direito sucessório, o filho adotivo irá receber o legado a que tem direito.

Este entendimento é reforçado pelo artigo 1.596 do Código Civil, onde refere a igualdade entre os filhos, sendo eles nascidos, ou não nas núpcias, ou os adotivos, vedando qualquer forma de distinção entre eles.Tendo em vista a causa de impedimento, o cônjuge está em favorecimento quando comparado aos outros herdeiros. O cônjuge é herdeiro necessário, pois concorre com os ascendentes e os descendentes. Fazendo com que ele esteja na mesma linha de sucessão ao descendente. Por meio de lei o cônjuge recebe quantia igual à descendente, que recebem por cabeça, e caso sejam ascendentes, a parte não poderá ser menor à quarta parte da herança.

O cônjuge que concorre com o ascendente em primeiro grau, receberá um terço da herança, se existir apenas um ascendente, no caso de mais de um, recolherá a metade da herança. Quando versar sobre 
o regime de separação voluntária dos bens, será na totalidade da herança, mas se for à participação final nos aquestos não há meação, pois não há concorrência.

O regime de comunhão parcial de bens é o mais utilizado no Brasil, os bens adquiridos na constância do casamento, será a metade de cada, só não serão comunicados os bens adquiridos antes do casamento, e aqueles que forem recebidos por doação ou herança. Ademais, serão sub- rogados os bens de uso pessoal, livros, instrumentos pessoais de cada cônjuge. Se forem de valores consideráveis, e adquiridos com dinheiro comum do casal, devem entrar na comunhão. E nestes casos irá ocorrer a meação, que é a divisão igual dos bens do casal, o cônjuge meeiro irá receber metade dos bens comuns do casal, no caso de cônjuge sobrevivente, ele não herda apenas recebe o que é seu por direito.

Caso o testador faça a nomeação de herdeiros de modo individual, deverá ser observado o artigo 1.905 do Código Civil, "Se o testador nomear certos herdeiros individualmente e outros coletivamente, a herança será dividida em tantas quotas quantos forem os indivíduos e os grupos designados."

E caso o testador determine as quotas para cada herdeiro e não absorva a herança de forma total, seguirá o artigo 1.906 do Código Civil, se "forem determinadas as quotas de cada herdeiro, e não absorverem toda a herança, o remanescente pertencerá aos herdeiros legítimos, segundo a ordem da vocação hereditária."

\section{MULTIPARENTALIDADE}

A possibilidade da inclusão de mais uma mãe/ pai no registro de pessoa natural, já se encontra como uma realidade no Brasil. A efetivação da multiparentalidade se encontra possível com a consolidação do afeto entre o infante e a pessoa pela qual ela passou a ter grande consideração, como poderá ser observado nos próximos itens da presente sessão.

\subsection{NOÇÕES HISTÓRICAS E CONCEITO}

Com base no ordenamento jurídico brasileiro, decisões de $1^{\circ}$ e $2^{\circ}$ grau que reconheceram a multipaternidade datam de 2012, a multiparentalidade já era reconhecida em outras jurisdições da América.

Logo, a primeira decisão brasileira nesse sentido foi prolatada pela magistrada da comarca da cidade de Ariquemes-RR, nos autos de n. 0012530-95.2010.8.22.002, onde a juíza que presidia o feito manteve a paternidade como estava no registro e a socioafetiva do padrasto da autora, incluindo o 
pai biológico, reconhecendo-se desta maneira a possibilidade da dupla paternidade registral, a biológica e a socioafetiva (TJRO, 2012).

Outro caso de igual valia para ordenamento jurídico brasileiro, é o do processado nos autos de n.ำ 0038958-54.2012.8.16.0021, onde o juiz de direito da Vara da Infância e da Juventude da comarca de Cascavel-PR, ao receber a inicial de pedido de adoção, com consentimento do pai biológico, determinou-se que o requerente procedesse com emenda à inicial para que fosse objeto da inicial além da inclusão da paternidade socioafetiva a manutenção da paternidade biológico. Pois, de acordo com o magistrado, ambos exerciam o papel de pai na vida da adolescente, excluindo um deles, privaria a adolescente da convivência com um deles (TJPR, 2013).

Em famílias que foram reconstituídas, os pais foram casados por um tempo, tiveram filhos e reconstituíram suas famílias. O novo companheiro da genitora passa a criar o filho como se fosse dele, restando então a filiação biológica e a socioafetiva.

Apesar de incipiente, desafiava os magistrados, os números de decisões que consideravam a multiparentalidade segundo Karina Barbosa Franco, (2021, p. 83): "foram crescendo de forma progressiva, com maior destaque com a decisão do Supremo Tribunal) Federal nos autos do RE no 898.060/SC, em 2016, através do Tema 622 do Pretório Excelso, que garantiu repercussão geral à matéria.

Até que chegasse ao Supremo, havia duas correntes jurisprudenciais, em uma indicava a prevalência da relação com base no afeto, vivenciada pelas partes sobre o vínculo biológico, na outra, mesmo que diante da relação socioafetiva consolidada deveria prosperar o vínculo parental biológico sobre o socioafetivo.

O STJ considerava a prevalência do vínculo biológico sobre o socioafetivo, em casos de pedido judicial de reconhecimento da paternidade formulado pelo filho, se o pedido fosse apresentado pelo genitor e o socioafetivo para desconstituição da paternidade através da adoção.

Em 21.06.2019, o STF quebrou a estrutura binária de filiação adotando um posicionamento diferente do STJ, nos autos do RE no 898.060/SC, (No RE 898.060/SC, Rel. Min. Luiz Fux, j.21.09.16, publicado no Informativo no 840), reconhecida (Tema 622), ao tratar do leading case apresentado, onde o caso envolvia uma discussão sobre a prevalência de paternidade socioafetiva devidamente consolidada em consonância com a biológica não vivenciada, fazendo que avançasse.

Segundo Cassettari (2017, p. 118) sobre os votos do presente recurso extraordinário: 
Por maioria de votos, o Plenário do Supremo Tribunal Federal (STF) fixou a tese de repercussão geral no Recurso Extraordinário RE 898.060-SC, em que ficou definido que a existência de paternidade socioafetiva não exime de responsabilidade o pai biológico. A tese fixada servirá de parâmetro para futuros casos semelhantes e para 35 processos sobre o tema que estão sobrestados (suspensos) nos demais tribunais.

A paternidade sobrevinda da socioafetiva, em registro ou não, de nada irá impedir o vínculo de filiação concomitante com a origem biológica. Pelo STF ficou reconhecida a existência da multiparentalidade, admitindo a concomitância de filiação, afetiva e biológica.

A multiparentalidade é quando há a possibilidade de registrar o filho por mais de uma mãe ou pai, podendo ser uma filiação biológica e socioafetiva. No Código Civil, em seu artigo 1.593 trata que "O parentesco é natural ou civil, conforme resulte de consangüinidade ou outra origem." Quando cita outra origem, o entendimento é que a filiação seja por adoção ou socioafetividade.

No mesmo sentido o enunciado da CJF, de número 256, aduz: "A posse do estado de filho (parentalidade socioafetiva) constitui modalidade de parentesco civil." Posse do estado de filho é considerar a pessoa como se filho fosse, não tendo como distingui-los, podendo ser biológicos, adotivos ou socioafetivos.

\subsection{PROCEDIMENTOS JUDICIAIS E EXTRAJUDICIAIS}

A multiparentalidade faz com que os direitos e obrigações sejam recíprocos como os filhos biológicos. Em tempos antigos somente poderia ser realizado nos cartórios os casos que fossem de inseminação, por casais homoafetivos e necessitava da comprovação do laudo médico.

Para que fosse alterado o nome da criança, com a inclusão do nome do pai socioafetivo, somente seria possível a alteração mediante processo judicial. De acordo com o artigo 10, $\S 1$ 을 do Provimento $n^{\circ} 63$ de 2017, "O reconhecimento voluntário da paternidade ou maternidade será irrevogável, somente podendo ser desconstituído pela via judicial, nas hipóteses de vício de vontade, fraude ou simulação". (Provimento no63 de 14 de novembro de 2017).

Nas relações que tratarem da multiparentalidade deverá ser observado o interesse da criança, sem observar o que é prioridade para os pais, tendo em vista que todos serão iguais. Ao tratar da multiparentalidade pela via extrajudicial, houve o provimento no 83 de 2019 do CNJ, que trouxe modificações ao provimento anterior, quando tratava da maternidade/paternidade socioafetiva, pela via extrajudicial, como o critério de idade ser acima de 12 anos, e caso maior de 18 anos, que mantenha 
vínculo estável, e que possa ser socialmente verificado, existindo a comprovação da afetividade, além de que necessite de parecer do Ministério Público. (Provimento no 83 de 14 de agosto, 2019).

O pedido de providência foi fundamentado com embasamento da inexistência de regramento sobre a matéria, mesmo existindo reconhecimento jurídico da maternidade/ paternidade socioafetiva na jurisprudência e na literatura pátria, e também sobre os provimentos das Corregedorias por diversos estados que regulamentavam a formalização extrajudicial da paternidade socioafetiva.

Para que ocorresse a formalização socioafetiva, somente era possível por meio judicial. O meio extrajudicial não era permitido. Não eram consentidas as partes que pudessem encaminhar diretamente ao cartório de registro de pessoas que constasse no documento a filiação socioafetiva.

Tendo em vista Karina Barbosa Franco (2021, pág. 106) informa sobre iniciou a discussão para o reconhecimento da multiparentalidade:

A possibilidade do reconhecimento pela via extrajudicial começou a ser discutida por Christiano Cassettari, cuja ideia lançada foi acolhida pelo desembargador Jones Figueiredo Alves, sendo o estado de Pernambuco o pioneiro em publicar um provimento neste sentido. Após, seguiram-se os estados do Ceará, Maranhão, Santa Catarina, Amazonas, Paraná e Mato Grosso do Sul.

O reconhecimento extrajudicial da parentalidade socioafetiva de acordo com o artigo 10 do provimento 63 de 2017, "O reconhecimento voluntário da paternidade ou da maternidade socioafetiva de pessoas acima de 12 anos será autorizado perante os oficiais de registro civil das pessoas naturais."

O ápice do reconhecimento da multiparentalidade se deu com a decisão do STF que foi a de no 898.060/Santa Catarina. No artigo 14 do provimento, dispõe: “O reconhecimento da paternidade ou maternidade socioafetiva somente poderá ser realizado de forma unilateral e não implicará o registro de mais de dois pais e de duas mães no campo FILIAÇÃO no assento de nascimento". (Provimento no 63 de 20 de novembro, 2017).

O referido dispositivo não era claro, se iria aplicar aos casos do reconhecimento da multiparentalidade. Não seria certeza a possibilidade de que o CNJ permitiria o reconhecimento por meio extrajudicial da socioafetividade, nos casos apenas para ter pai e mãe, ou duas mães e dois pais, mas se permitiria o reconhecimento de mais uma mãe ou mais um pai. 
A multiparentalidade é reforçada pelo artigo 11, §3ㅇ, quando preconiza que constarão no termo, além dos dados de pai ou mãe socioafetivo, os dados no campo de Filiação e do filho constarem no registro, o registro deve colher a assinatura da mãe e pai biológicos do reconhecido, se for menor de idade:

Art. 11. O reconhecimento da paternidade ou maternidade socioafetiva será processado perante o oficial de registro civil das pessoas naturais, ainda que diverso daquele em que foi lavrado o assento, mediante a exibição de documento oficial de identificação com foto do requerente e da certidão de nascimento do filho, ambos em original e cópia, sem constar do traslado menção à origem da filiação.

§ 3 Constarão do termo, além dos dados do requerente, os dados do campo FILIAÇÃO e do filho que constam no registro, devendo o registrador colher a assinatura do pai e da mãe do reconhecido, caso este seja menor.

Sendo assim, se a criança tiver mãe e pai biológicos, sendo eles registrais, pode ser feito o reconhecimento extrajudicial da parentalidade se ambos os pais biológicos estiverem em concordância. A regra vale também se o filho tiver no registro um pai socioafetivo, e a mãe biológica, se o pai biológico quiser proceder ao reconhecimento posteriormente, os pais no registro deverão estar em anuência.

Foi publicado o Provimento CNJ de no 83, em 14 de agosto de 2019, que faz alteração a Seção II do Provimento $n$ o 63/2017, autorizando o reconhecimento da maternidade ou paternidade socioafetiva perante os oficiais de registro civil das pessoas naturais, para aqueles que forem maiores de 12 anos. A nova redação do artigo 10 ficou da seguinte forma: "O reconhecimento voluntário da paternidade ou da maternidade socioafetiva de pessoas acima de 12 anos será autorizado perante os oficiais de registro civil das pessoas naturais."

E acrescentou o artigo 10-A:

A paternidade ou a maternidade socioafetiva deve ser estável e deve estar exteriorizada socialmente.

§ 1으 0 registrador deverá atestar a existência do vínculo afetivo da paternidade ou maternidade socioafetiva mediante apuração objetiva por intermédio da verificação de elementos concretos.

$\S 2$ 2 0 requerente demonstrará a afetividade por todos os meios em direito admitidos, bem como por documentos, tais como: apontamento escolar como responsável ou representante do aluno; inscrição do pretenso filho em plano de saúde ou em órgão de previdência; registro oficial de que residem na mesma unidade domiciliar; vínculo de conjugalidade - casamento ou união estável - com o ascendente biológico; inscrição como dependente do requerente em entidades associativas; fotografias em celebrações relevantes; declaração de testemunhas com firma reconhecida. 
§ 3ำ A ausência destes documentos não impede o registro, desde que justificada a impossibilidade, no entanto, o registrador deverá atestar como apurou o vínculo socioafetivo.

$\S 4$ ㅇ Os documentos colhidos na apuração do vínculo socioafetivo deverão ser arquivados pelo registrador (originais ou cópias) juntamente com o requerimento.

Como pode ser observado no artigo 10, prevê que a maternidade e a paternidade socioafetivas devem ser comprovadas mediante estabilidade e exteriorização social, a modo que sejam verificadas pelas Serventias de Registro de Pessoas Naturais, no $§ 2^{\circ}$ trata de um rol exemplificativo, que exige a atuação apurada por parte do registrador.

A alteração do provimento $\mathrm{n}$ ㅇ 83, teve a inclusão de dois parágrafos ao artigo 14 do Provimento $\mathrm{n}$ 은 $63 / 17$, que tratam a respeito da multiparentalidade:

Art. 14. O reconhecimento da paternidade ou maternidade socioafetiva somente poderá ser realizado de forma unilateral e não implicará o registro de mais de dois pais e de duas mães no campo FILIAÇÃO no assento de nascimento.

$\S 1$ a Somente é permitida a inclusão de um ascendente socioafetivo, seja do lado paterno ou do materno.

$\S 2$ 2 A inclusão de mais de um ascendente socioafetivo deverá tramitar pela via judicial.

O Provimento $n$ ㅇ 63/17, autorizou o registro extrajudicial de multiparentalidade no registro civil, sendo limitados duas mães e dois pais, no máximo, e também apenas um ascendente socioafetivo, mesmo que materno ou paterno. A principal preocupação do legislador foi evitar vínculos sucessivos, já que a posse de estado de filho necessita de tempo de convivência.

Tendo em vista a segunda corrente do Direito nas relações parentais, é sustentado que a possibilidade do reconhecimento da multiparentalidade através da via extrajudicial para aqueles com idade superior a 18 anos, caso seja crianças, somente ocorrerá por ação judicial, devendo o Ministério Público intervir, equipe disciplinar de psicólogos e assistentes sociais, para que através da imparcialidade, para que verifiquem se de fato há a multiparentalidade, devendo assegurar os melhores interesses do infante.

\subsection{EFEITOS E CONSEQUÊNCIAS}

O reconhecimento da multiparentalidade serve para equiparar o vínculo familiar, derivado de afetividade ou consangüinidade, os direitos e deveres são simultâneos para mais de uma mãe e/ou pai. Ao filho será atribuída mais de uma mãe e/ou pai, como todos os demais vínculos provenientes 
dos mesmos. Acarretando repercussões familiares formadas pelo parentesco socioafetivo ou pelo biológico.

Karina Barbosa Franco (2021, p. 146) aduz “Como decorrência, são produzidos efeitos jurídicos, como corrobora tese firmada pelo STF: a partir da declaração na sentença e de seu lançamento no registro do nascimento, refletindo a verdade real."

Na nova forma de filiação é essencial a averbação no assento de nascimento do filho para segurança das partes e de terceiros, já que produz diversos efeitos, como por exemplo, o impedimento matrimonial, restrições relacionadas ao nepotismo.

No mais o (IBDFAM), aprovou no IX Congresso Brasileiro de Direito de Família, o enunciado de número 9: "A multiparentalidade gera efeitos jurídicos." Para que seja configurada a multiparentalidade, devem-se ser observados alguns efeitos.

Para Ana Carolina e Renata de Lima, (2015, p. 24):

Com o estabelecimento do múltiplo vínculo parental, serão emanados todos os efeitos de filiação e de parentesco com a família estendida, pois, independente da forma como esse vínculo é estabelecido, sua eficácia é exatamente igual, principalmente porque irradia do princípio da solidariedade, de modo que instrumentaliza a impossibilidade de diferença entre suas consequências.

Há também a possibilidade de que alguém faça juz a mais de uma herança ou até mesmo mais de pensão alimentícia.

\subsubsection{SUCESSÃO}

O direito constitucional à herança é mantido em cláusula pétrea conforme, artigo 5으, inciso XXX, decorrente da filiação, abordando a filiação múltipla, devendo ser vista como uma causa natural dos ascendentes a favor do descendente de primeiro grau.

No Enunciado de no 632, aprovado na VII Jornada de Direito Civil, trata: “Art. 1.596: Nos casos de reconhecimento de multiparentalidade paterna ou materna, o filho terá direito à participação na herança de todos os ascendentes reconhecidos."

O filho poderá receber duas heranças a partir do reconhecimento dos ascendentes, independentemente da forma que seja o reconhecimento, os filhos terão os direitos sucessórios, devendo ser observado o artigo 227,§6으 da CRFB e também o artigo 1.596 do Código Civil.

A sucessão legítima ocorre dos vínculos familiares mantidos com o de cujus e seus sucessores, de qualquer forma que seja a origem. Ademais, a ordem da vocação hereditária não faz diferenciação se 
o parentesco é de origem biológica ou socioafetiva, ou que sejam ambos, como pode ser visto na multiparentalidade.

Ao tocante aos descendentes, em primeiro grau estão os filhos do de cujus, estáresguardada pela isonomia trazida pela Constituição Federal de 1988, em seu artigo 227, §6o, e pelo artigo 1.596 do Código Civil, sendo vedado qualquer tipo de tratamento desigual entre os filhos, nenhuma filiação deve ser discriminada.

Tendo em vista que as famílias vêm sofrendo alterações, o filho irá entrar na sucessão de suas mães e/ ou pais, estendendo aos demais descendentes.

Na divisão da herança, devem ser aplicadas as regras do artigo 1.835 do Código Civil: "Na linha descendente, os filhos sucedem por cabeça, e os outros descendentes, por cabeça ou por estirpe, conforme se achem ou não no mesmo grau. " Sendo assim, a herança será dividida sem distinção entre os filhos biológicos, multiparentais ou socioafetivos.

A sucessão dos ascendentes determina que a herança tenha duas linhas, a materna e a paterna, segundo a proximidade de parentesco do falecido. Nos termos do §2, do artigo 1.836 do Código Civil, serão $50 \%$ do montante para cada uma das linhas. Ao filho de múltiplos pais cabe o direito de herança os quantos ele tiver, devendo ser recíproco aos pais, se é recíproco ao filho deverá ser aos pais também.

Nos casos em que o autor da herança não deixar descendentes, os ascendentes socioafetivos e biológicos irão participar da herança de forma concorrente. Caso seja dois pais ( um biológico e outro socioafetivo) e apenas uma mãe, ela herdará metade da herança e os pais a outra metade. No Enunciado no 642 da VII Jornada de Direito Civil compreende que:

Art. 1.836: Nas hipóteses de multiparentalidade, havendo o falecimento do descendente com o chamamento de seus ascendentes à sucessão legítima, se houver igualdade em grau e diversidade em linha entre os ascendentes convocados a herdar, a herança deverá ser dividida em tantas linhas quantos sejam os genitores.

A justificativa é baseada no $§ 2^{\circ}$ do artigo 1.836 do Código Civil, que diz que a divisão se dá através dos troncos familiares. Para que o legislador conseguisse atingir o que tratava da multiparentalidade a herança seria dividida em quantas linhas forem necessárias, a partir dos genitores.

O artigo 1.837 do Código Civil trata que "Concorrendo com ascendente em primeiro grau, ao cônjuge tocará um terço da herança; caber-lhe-á a metade desta se houver um só ascendente, ou se maior for 
aquele grau." No caso de cônjuge ou companheiro sobrevivente deve ser mantida a cota diferenciada tratada no artigo citado, mesmo que caracterizada a multiparentalidade.

Existindo a multiparentalidade na primeira linha de ascendente (três ou mais mães/pais), o cônjuge terá direito a $1 / 3$ da herança, e os $2 / 3$ restantes serão divididos entre as mães e/ou pais. Quando for de grau superior ao primeiro, será cabível ao cônjuge ou companheiro sobrevivente a metade da herança, e a outra metade restante entre os ascendentes, a partir das linhas formadas do vínculo parental. A multiparentalidade se estende por toda a árvore genealógica, também incluindo a linha colateral.

Em observância aos irmãos, o legislador trouxe tratamento diferente, sejam eles bilaterais ou unilaterais, o artigo 1.834 do Código Civil, "Concorrendo à herança do falecido irmãos bilaterais com irmãos unilaterais, cada um destes herdará metade do que cada um daqueles herdar."

Ao tocante da multiparentalidade, é cabível a múltipla irmandade, além dos irmãos unilaterais e bilaterais, terão os trilaterais e os quadrilaterais. A sucessão dos irmãos é extensível aos sobrinhos, na existência de dois ou mais vínculos parentais não deve ser diferenciados, equiparando o irmão multiparental ao bilateral na sucessão.

A multi-hereditariedade é a possível forma de que o filho possa reclamar a sua cota pertencente a todas as suas mães e pais, para que atenda os interesses patrimoniais. Para Calderón e Grubert,(2010, p. 285-298 apud FRANCO, 2021) apontam as seguintes conclusões.

A primeira é que é possível um filho herdar de todos os seus múltiplos ascendentes. A segunda é que a divisão da herança entre os ascendentes em caso de morte do filho deve ocorrer de maneira igualitária entre eles. A terceira é que deve seguir sendo observada a distinção entre o direito de filiação e o direito ao conhecimento da ascendência genética, cabendo analisar profundamente cada caso concreto para se apurar a melhor solução. A quarta, e última, é que se faz necessário atentar às demandas abusivas, as quais podem vir a exigir uma solução distinta, que não estabeleça filiação, à luz dos demais princípios e regras da juscivilística brasileira.

Conclui-se que os efeitos jurídicos a partir da multiparentalidade é com luz dos valores constitucionais, primado da isonomia entre os pais e filhos, biológicos e socioafetivos. As aplicações das soluções que tratarem da multiparentalidade deverão ter embasamento nos princípios constitucionais.

EMENTA: RECURSO EXTRAORDINÁRIO. REPERCUSSÃO GERAL RECONHECIDA. DIREITO CIVIL E CONSTITUCIONAL. CONFLITO ENTRE PATERNIDADES SOCIOAFETIVA E BIOLÓGICA. PARADIGMA DO CASAMENTO. SUPERAÇÃO PELA CONSTITUIÇÃO DE 1988. EIXO CENTRAL DO DIREITO DE FAMÍLIA: DESLOCAMENTO PARA O PLANO 
CONSTITUCIONAL. SOBREPRINCÍPIO DA DIGNIDADE HUMANA (ART. 1ㅇ, III, DA CRFB). SUPERAÇÃO DE ÓBICES LEGAIS AO PLENO DESENVOLVIMENTO DAS FAMÍLIAS. DIREITO À BUSCA DA FELICIDADE. PRINCÍPIO CONSTITUCIONAL IMPLÍCITO. INDIVÍDUO COMO CENTRO DO ORDENAMENTO JURÍDICO - POLÍTICO. IMPOSSIBILIDADE DE REDUÇÃO DAS REALIDADES FAMILIARES A MODELOS PRÉ-CONCEBIDOS. ATIPICIDADE CONSTITUCIONAL DO CONCEITO DE ENTIDADES FAMILIARES. UNIÃO ESTÁVEL (ART. 226, § 3 o, CRFB) E FAMÍLIA MONOPARENTAL (ART. 226, § 4 ㅇ, CRFB).VEDAÇÃO À DISCRIMINAÇÃO E HIERARQUIZAÇÃO ENTRE ESPÉCIES DE FILIAÇÃO (ART. 227, § $6 \circ$, CRFB). PARENTALIDADE PRESUNTIVA, BIOLÓGICA OU AFETIVA. NECESSIDADE DE TUTELA JURÍDICA AMPLA. MULTIPLICIDADE DE VÍNCULOS PARENTAIS. RECONHECIMENTO CONCOMITANTE. POSSIBILIDADE. PLURIPARENTALIDADE. PRINCÍPIO DA PATERNIDADE RESPONSÁVEL (ART. 226, $\S 7$, CRFB). RECURSO A QUE SE NEGA PROVIMENTO. FIXAÇÃO DE TESE PARA APLICAÇÃO A CASOS SEMELHANTES. (STF, Recurso Extraordinário 898.060, 2021).

No presente recurso a suprema corte afirmou que "a paternidade socioafetiva, declarada ou não em registro público, não impede o reconhecimento do vínculo de filiação concomitante baseado na origem biológica, com os efeitos jurídicos próprios" ( Repercussão Geral 622). Além de solucionar questões sobre a parentalidade socioafetiva, também abriu portas para a multiparentalidade.

As consequências não são apenas no direito de família, como também no direito das Sucessões e porventura no Direito Previdenciário, quando se reconhece para fins de sucessão, também deve ser reconhecido para dependente ao tocante à previdência.

\section{CONCLUSÃO}

Conforme verificado ao longo da presente pesquisa, o conceito de família modificou-se e continua a evoluir na sociedade contemporânea, sendo que tal instituto anteriormente apenas vinculado à laços biológicos passou a adotar a teoria dos laços afetivos. Ademais, o ordenamento jurídico vem adotando frequentemente tal teoria como base constitucional para suas decisões, superando até mesmo o direito postulado acerca dos direitos e deveres oriundos da parentalidade biológica.

Nesse sentido, a Carta Política traz princípios chaves que permitem a interpretação extensiva do conceito de parentalidade afetiva, dentre eles o da dignidade da pessoa humana, da solidariedade familiar e a equiparação dos filhos e a vedação à discriminação entre filhos biológicos e socioafetivos, permitindo uma interpretação e aplicação análoga de tais princípios às regras do direito de família e sucessões, sob a óptica de um ordenamento jurídico neoconstitucionalista. 
O direito sucessório possui raízes antigas, remontando à antiga Grécia antiga, não é fato estranho que este tenha sofrido mudanças ao longo dos séculos. Contudo, com base na presente pesquisa é possível inferir que uma das mudanças mais drásticas vem ocorrendo no direito contemporâneo com o advento da multiparentalidade.

Isto porque o direito sucessório, em suas raízes, encontrava-se intrinsecamente ligado aos laços consanguíneos e posteriormente aos registrais. Transmitindo a posse dos bens de um parente falecidos aos que a ele se encontravam vinculados biologicamente ou por filiação registral, previstos em uma linha sucessória específica, encontrando-se o rol dos "herdeiros legítimos" especificado no art. 1.829 do Código Civil.

No entanto, a multiparentalidade rompe tal regramento e cria novos direitos e deveres entre parentes biológicos e socioafetivos, posto que os doutrinadores brasileiros e os tribunais de justiça do país vêm frequentemente reconhecendo as obrigações oriundas desses laços afetivos, permitindo a dupla paternidade ou maternidade em assentos de nascimento, reconhecendo a obrigação alimentícia em casos de paternidade socioafetiva, assim como a sucessão de bens por laços socioafetivos.

Neste liame, observou-se que o ordenamento jurídico brasileiro vem buscando adaptar-se ao fenômeno da multiparentalidade, inclusive, buscando do CNJ criar meios para o seu reconhecimento de paternidade/maternidade sócio afetiva também no âmbito extrajudicial, o que por consequência, abre caminhos para o reconhecimento da multi-hereditariedade no ordenamento jurídico.

Dessarte, no que tange à multiparentalidade têm-se que as cortes pátrias vem adotando o princípio da constitucional da vedação de diferenciação entre os filhos biológicos e os afetivos, interpretação esta, que conforme os julgados citados, se estende ao direito sucessório, uma vez que reconhecem aos filhos socioafetivos a qualidade de herdeiros legítimos, transferindo-se o direito de sucessão ao herdeiro socioafetivo sem qualquer discrepância na partilha, por força dos princípios constitucionais, fazendo jus a seu quinhão em par de igualdade aos herdeiros biológicos.

Todavia, para que tenhamos grandes avanço nesse campo do direito, necessário se faz a criação de normas específicas que acrescentem tais herdeiros socioafetivos no rol de herdeiros legítimos, sem margens à discussão pelos demais herdeiros, visando garantir o grau de igualdade prometido pela norma constitucional, evitando-se o grau de subjetividade da que circunda a matéria, uma vez que transfere ao judiciário o poder de decisão acerca dos requisitos necessários para ser considerado herdeiro socioafetivo, podendo eventualmente em uma interpretação positivista da lei criar exclusão e discricionariedade na partilha de bens. 


\section{Multiparentalidade E Seus Efeitos Sucessórios}

Dessarte, o presente artigo chega à conclusão de que embora iniciada a discussão da multiparentalidade e a multi-hereditariedade, estase encontra longe de acabar, posto que ainda encontra-se num campo subjetivo da interpretação do judiciário, necessitando de regulamentação específica por parte do legislativo a fim de cumprir os preceitos constitucionais acerca do direito de família e sucessão. 


\section{REFERÊNCIAS}

BRASIL, STF - Supremo Tribunal Federal. Recurso Extraordinário 898.060 Santa Catarina. Relator Ministro Luiz Fux. julgado em 21/09/2016. Disponível

em <https://redir.stf.jus.br/paginadorpub/paginador.jsp?docTP=TP\&docID=13431919>. Acesso em 22 de outubro de 2021.

. (2002). Lei no 10.406 de 10 de janeiro de 2002. Lei de Introdução as Normas do Direito Brasileiro. <http://www.planalto.gov.br/ccivil_03/leis/2002/l10406compilada.htm>. Acesso em 31 de outubro de 2021.

- Constituição (1988). Constituição da República Federativa do Brasil. Disponível em<http://www.planalto.gov.br/ccivil_03/constituicao/constituicao.htm>. Acesso em 31 de outubro de 2021.

. Conselho Nacional de Justiça. Provimento no63 (2017, 14 de novembro).

<https://atos.cnj.jus.br/files/provimento/provimento_63_14112017_19032018150944.pdf>. Acesso em 31 de outubro de 2021.

.Conselho Nacional de Justiça. Provimento n-83 (2019, 14 de agosto).<https://atos.cnj.jus.br/files/provimento/provimento_83_14082019_15082019095759.pdf

<. Acesso em 31 de outubro de 2021.

COELHO, Fábio Ulhoa. Curso de Direito Civil. Família-Sucessões. 5a ed. São Paulo. 2012

DIAS, Maria Berenice. Manual de Direito das famílias [livro eletrônico]. 4ạed. em e-book, baseada na 11a ed. impressa.

ENUNCIADOS IBDFAM. IBDFAM.<https://www.ibdfam.org.br/conheca-o-ibdfam/enunciados-ibdfam.

>. Acesso em 22 de outubro de 2021.

FARIAS,Cristiano Chaves de. Curso de direito civil: famílias. I Cristiano Chaves de Farias, Nelson Rosenvald - 9. ed. rev. e atual - Salvador: Ed JusPodlvm, 2016.

FRANCO, Karina Barbosa. Multiparentalidade: uma analise dos limites e efeitos jurídicos práticos sob o enfoque do princípio da afetividade. Belo Horizonte: Fórum, 2021. (Coleção Fórum Direito Civil e seus Desafios Contemporâneos, vol.6).

GAGLIANO, Pablo Stolze. Novo curso de direito civil, volume 7 : direito das sucessões / Pablo StolzeGagliano, Rodolfo Pamplona Filho. - 6. ed. - São Paulo : Saraiva Educação, 2019.

GONÇALVES, Carlos Roberto. Direito civil brasileiro, volume 6 : direito de família / Carlos Roberto Gonçalves. - 14. ed.- São Paulo : Saraiva, 2017.

Carlos Roberto. Direito civil brasileiro, volume 7 : direito das sucessões / Carlos Roberto Gonçalves. - 8. ed. - São Paulo : Saraiva, 2014. 
LÔBO, Paulo. Direito civil: famílias / Paulo Lôbo. - 7. ed. - São Paulo : Saraiva, 2017. 2018.

Paulo. Direito civil: volume 6 : sucessões / Paulo Lôbo. - 4. ed. - São Paulo : Saraiva Educação,

MADALENO, Rolf. Direito de família / Rolf Madaleno. - 8. ed., rev., atual. eampl. - Rio de Janeiro: Forense, 2018.

PEREIRA. Caio Mário da Silva, Instituições de direito civil - Vol. V / Atual. Tânia da Silva Pereira. - 25. ed. rev., atual. E ampl. - Rio de Janeiro: Forense, 2017.

PARANÁ, Tribunal de Justiça do Estado. Ação de Adoção n.o 0038958-54.2012.8.16.0021.Comarca de Cascavel. Juíz Sérgio Luiz Kreuz. Vara da Infância e Juventude. 2013. Disponível em:<http://www.flaviotartuce.adv.br/assets/uploads/jurisprudencias/201302281223270.multiparen t_sentpr.PDF>. Acesso em 22 de outubro de 2021.

RONDÔNIA. Tribunal de Justiça do Estado. Processo n. 0012530-95.2010.8.22.0002. Comarca de Ariquemes. Juíza DeisyCristhian Lorena de Oliveira Ferraz. Decisão: 13 mar. 2012. Disponível em: <https://www.tjro.jus.br/appg/pages/DetalhesProcesso.xhtml>. Acesso em 22 de outubro de 2021

STOLZE, Pablo; Pamplona Filho, Rodolfo. Manual de direito civil - volume único / Pablo Stolze; Rodolfo Pamplona Filho. - 4. ed. - São Paulo : Saraiva Educação, 2020.

TARTUCE, Flávio. Direito Civil, v.4.9 ed. Rio de Janeiro, 2017.

Flávio. Manual de Direito Civil: volume único / Flávio Tartuce. - 11. ed. - Rio de Janeiro, Forense; METODO, 2021.

VENOSA, Sílvio de Salvo. Direito civil: família / Sílvio de Salvo Venosa. - 17. ed. - São Paulo: Atlas, 2017. 


\section{Capítulo 2}

\section{doi $10.37423 / 211205155$}

\section{A EFETIVAÇÃO DA PENHORA NO PROCESSO CIVIL À LUZ DO PRINCÍPIO DA DIGNIDADE DA PESSOA HUMANA E GARANTIA DO MÍNIMO EXISTENCIAL}

EMILLY AQUINIS GOMES E GOUVEIA

UNIVERSIDADE LUTERANA DO BRASILULBRA
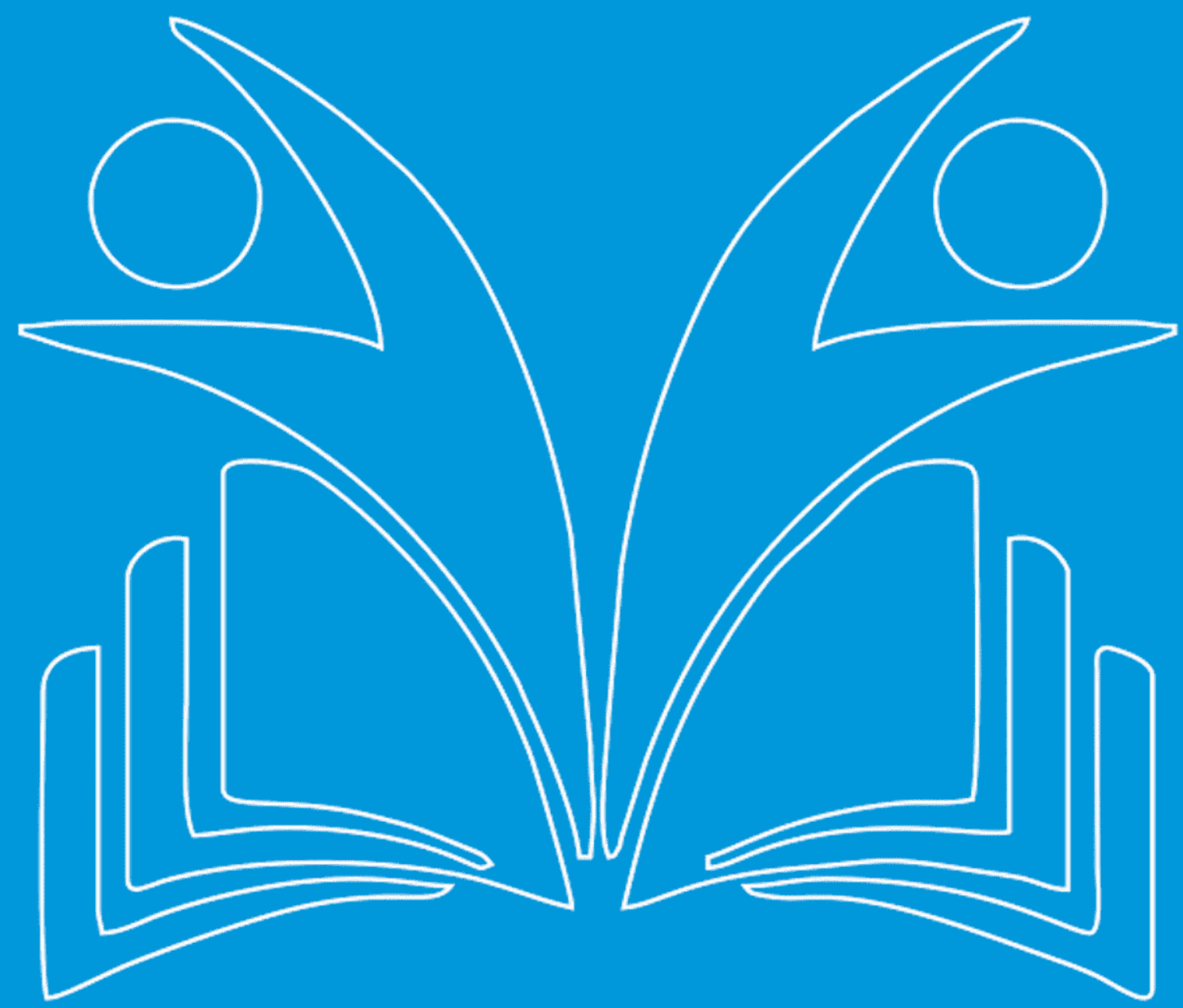
Resumo: O presente artigo possui como tema a efetivação da penhora no processo civil à luz do princípio da dignidade da pessoa humana e garantia do mínimo existencial, considerando-se que os princípios constantes na Constituição da República Federativa do Brasil de 1988 e nos demais códigos formam a base do direito e todo ato processual deve ser pautado nas referidas garantias constitucionais. Mediante essa afirmação, a problemática faz-se em saber: Há a possibilidade de uma correta aplicação e efetivação da penhora no processo de execução civil juntamente com a utilização do princípio da dignidade da pessoa humana e garantia do mínimo existencial ao indivíduo? A partir dessa indagação abordam-se hipóteses a fim de solucionar o problema proposto, pontuando que o instituto da penhora é válido e justo mas, deve ser utilizado com base nos princípios constitucionais buscando um equilíbrio na relação processual. Para tanto, tem-se como objetivo geral a abordagem de possibilidades para utilização da penhora no processo de execução civil e, de forma específica, a conceituação do instituto da penhora, analisando os princípios constitucionais, no que se refere à utilização dos mesmos no curso da execução e constrição e, ao findar, compreender e garantir a possibilidade de aplicação do princípio da dignidade da pessoa humana e o mínimo existencial. Ainda, o estudo justifica-se social, jurídico e academicamente, considerando que auxiliará na correta utilização da penhora, garantindo uma relação processual justa e equilibrada. Por fim, menciona-se que o presente artigo realiza-se mediante o método dedutivo através da pesquisa bibliográfica e teórica.

Palavras-chave: Penhora. Princípios. Dignidade. Humana. Equilíbrio. 


\section{INTRODUÇÃO}

O presente artigo tem como escopo perquirir sobre a efetividade do princípio da dignidade da pessoa humana e a garantia do mínimo existencial do indivíduo no que se refere a realização da penhora no processo de execução civil. No decorrer da relação jurídica, após o inadimplemento de uma das partes, uma das soluções encontradas para a satisfação da dívida é o instituto da penhora.

Os credores recorrem à penhora como forma de garantir o recebimento daquilo que lhes é devido, reclamando ao judiciário uma celeridade e efetividade, de modo a coibir o executado a adimplir a dívida existente. Ainda, a penhora é vista pelos credores como uma oportunidade de resolver situações conflituosas que se encontram no Poder Judiciário.

A problemática do presente artigo é uma busca a seguinte indagação: Há a possibilidade de uma correta aplicação e efetivação da penhora no processo de execução civil juntamente com a utilização do princípio da dignidade da pessoa humana e garantia do mínimo existencial ao indivíduo?

As hipóteses de solução do problema proposto em relação a ampla e correta utilização do princípio da dignidade da pessoa humana e garantia do mínimo existencial no decorrer do processo de execução civil aborda precipuamente a questão de menor sacrifício ao devedor e melhor satisfação ao credor, na busca de um equilíbrio para ambas as partes da relação processual.

Objetiva-se através dessa pesquisa, de forma geral, abordar as possibilidades de utilização da penhora no processo de execução civil e, especificamente, conceituar de forma clara e inequívoca o instituto da penhora de bens, analisar os princípios constitucionais, bem como os constantes no Código de Processo Civil e leis diversas no que tange à utilização dos mesmos no momento da constrição e, por fim compreender e garantir a possibilidade de se aplicar a dignidade da pessoa humana e o mínimo existencial durante a realização da penhora.

A busca pela efetividade do processo de execução, pauta-se nos princípios constitucionais , precisamente, na celeridade, efetividade, dignidade da pessoa humana e garantia do mínimo existencial, deixando-se sempre a premissa de que o Código de Processo Civil, em seus artigos 832 e 833, e a Lei no 8.009, de 29 de março de 1.990 dispõe sobre a impenhorabilidade de alguns bens.

Ainda, importante a ressalva de que existe uma ordem de bens a serem penhorados no caso do processo de execução civil, sendo que a mesma deve ser sempre observada, em acordo com o art. 835 do $\mathrm{CPC} / 15$, deixando a premissa de que os princípios devem ser atendidos em sua totalidade. 
O artigo justifica-se no meio social, jurídico e acadêmico considerando a análise da penhora no processo de execução civil, sua utilização prática, com a garantia de um processo justo e igualitário para as partes envolvidas na lide, bem como pela oportunização de conhecimento e garantia aos leigos.

Para a realização do artigo observa-se que parte de uma premissa geral, ou seja, estuda-se todo o conceito da penhora, bem como suas particularidades, além de desenvolver uma ampla definição de princípios constitucionais, partindo para uma premissa particular, qual seja, a análise específica da utilização da penhora diante dos princípios abordados, e, por não haver a inovação de conhecimentos, extrai-se o método dedutivo, qualificando-se o presente artigo como teórico e bibliográfico, bem como qualitativo pelo fato de ser pautado em obras bibliográficas de grande referência e relevância. Informa-se que o setor de conhecimento do artigo é interdisciplinar, tendo em vista a integração de matérias da área jurídica.

Em síntese, o primeiro tópico abordará de forma ampla o conceito de penhora, a ordem sequencial dos bens a serem penhorados neste instituto, bem como os bens que são tidos como impenhoráveis. Ainda falar-se-á no dever de cooperação do executado no curso do processo e nas possibilidades de modificação da penhora.

Já o segundo tópico terá como escopo a conceituação e análise dos princípios constitucionais, sendo eles, o da proporcionalidade e dignidade da pessoa humana, com enfoque no último.

Por fim, o terceiro tópico, o qual responde a problemática do artigo, tratará do escopo social existente na penhora, analisando também seus efeitos jurídicos, bem como apresentará a forma de utilização do princípio da dignidade da pessoa humana de forma a garantir o mínimo existencial e o equilíbrio da relação processual.

\section{PENHORA}

O termo penhor é de origem grega, da palavra "pignus" retratando que os bens do devedor permanecem sobre as mãos do credor, conferindo assim através deste sua garantia. A penhora é um instituto jurídico usado no processo de execução, que dá efetividade ao comando judicial, garantindo o crédito ao credor, tendo um avanço histórico ao decorrer dos anos partindo de um processo com excessos na execução e inexistência de proteção ao devedor, um grande exemplo é o "código de Hamurabi" que tinha como princípio a famosa frase "olho por olho, dente por dente", enfatizando traços de vingança operando no judiciário e indo, totalmente ao encontro do movimento de 
"reconstitucionalização" do direito privado trazendo a humanização dos procedimentos,garantindo o princípio da dignidade humana a todos que integrem o processo.

\subsection{CONCEITO}

Inicialmente, antes de adentrar ao conceito de penhora propriamente dito faz-se necessário demonstrar o momento em que a penhora irá ocorrer e como isso é realizado. Existem duas formas de satisfação da dívida, quais sejam, a ação de cobrança e a ação de execução de título, salientando que em ambos os casos pode ocorrer a penhora. Nas duas supramencionadas formas de satisfação da dívida, ressalta-se que uma das partes, no caso, o credor, apresenta o título extrajudicial, como exemplo um contrato assinado por 2 (duas) testemunhas ou um título judicial, como uma sentença exigindo o cumprimento de determinada obrigação. A partir desse momento é que se inicia os trâmites para a realização da penhora, conforme se discutirá com afinco nos próximos tópicos.

[...] a penhora é o ato inicial destinado a definir o bem do devedor que irá se submeter à expropriação judicial; é o primeiro ato expropriatório da execução através do qual se individualiza e afeta o bem (ou os bens) - entre todo o universo patrimonial do executado (devedor ou responsável) -, sobre os quais o ofício executivo deverá atuar para dar satisfação ao credor e submetê-los materialmente à transferência coativa. A consequência imediata da penhora é sujeitar os bens por ela alcançados aos fins da execução, ou seja, à satisfação do credor. (SAAD, 2019, p.02).

A penhora é conceituada no Dicionário Online como uma g arantia, ou seja, o que garante o cumprimento de um dever ou obrigação. Ademais, de forma jurídica, pode-se dizer que esse instituto é a realização de um ato, por parte do Poder Judiciário no que tange à constrição de bens do executado a fim de satisfazer a dívida do exequente (DINAMARCO, 2009).

Ainda, na intenção de conceituar de forma clara e específica a penhora, Olavo de Oliveira Neto , a trata como um ato a fim de individualizar os bens do devedor para que sejam submetidos a expropriação.

Ato executivo de afetação dos bens do executado, com a finalidade de individuar os bens que serão submetidos à expropriação e promover a conservação dos bens no estado em que se encontravam quando da realização do ato processual.(2018, p. 280-281)

O instituto da penhora também pode ser encontrado no Código de Processo Civil de 2015, especificamente em seus artigos 831 a 836. Sabido e consolidado que a penhora deve satisfazer a dívida através dos bens do devedor, recaindo sobre tantos bens quanto bastem para tal satisfação.

Art. 831. A penhora deverá recair sobre tantos bens quantos bastem para o pagamento do principal atualizado, dos juros, das custas e dos honorários advocatícios. 
Theodoro Jr. (2019, p.160) pontua que em encontro com o instituto da penhora, tem-se a obrigação e responsabilidade patrimonial, que é exatamente o instituto advindo do Código de Processo Civil, no qual compreende-se como possibilidade, sujeitar o bem do devedor a fim de satisfazer o credor, salvo algumas exceções que serão vistas adiante.

Nessa mesma linha, Marcelo Abelha, ensina que:

Deve-se perceber que a penhora constitui o ato executivo de identificação do bem do patrimônio do executado que se sujeitará à expropriação. Essa identificação implica pinçar e afetar, do universo patrimonial do executado, qual o bem ou bens que servem ao ato final de expropriação. (2016, p. 317)

Dentro do processo de penhora, faz-se a ressalva de que apenas o patrimônio do devedor é que responde pelas dívidas, jamais a sua pessoa, visto que conforme já consolidado pela doutrina pátria, bem como pelas jurisprudências, a responsabilidade do devedor é patrimonial e não pessoal.

Não obstante, superada eventual colaboração do executado, ainda quando instado a tanto por ordem judicial, a atividade executiva recairá sobre seu patrimônio, nunca sobre sua pessoa. (BUENO, 2016, p. 593)

\subsection{ORDEM SEQUENCIAL DA PENHORA}

A penhora, objeto de estudo da presente pesquisa, como já mencionado no subitem 2.1 é utilizada para garantir a satisfação de uma dívida, ou seja, anteriormente à penhora deve sempre haver uma dívida, na qual existam devedor e credor. Ainda, é de extrema importância a ressalva de que nenhuma pessoa terá seus bens penhorados sem o devido processo legal, princípio previsto na Constituição da República Federativa do

Brasil de 1988.

Observa-se ainda que será seguido todo o trâmite legal, sendo ordenado pelo juiz ao devedor que pague a dívida no prazo de 3 (três) dias sob pena de ter seus bens penhorados, tantos quantos bastem para a satisfação do valor referente à dívida. Ocorre que, existe uma ordem sequencial de bens a serem penhorados, com previsão no art. 835 e incisos do CPC/15.

Art. 835. A penhora observará, preferencialmente, a seguinte ordem:

I. - dinheiro, em espécie ou em depósito ou aplicação em instituição financeira;

II. títulos da dívida pública da União, dos Estados e do Distrito Federal com cotação em mercado;

III. títulos e valores mobiliários com cotação em mercado; IV veículos de via terrestre; 
IV. bens imóveis;

V. bens móveis em geral; VII - semoventes;

VI. navios e aeronaves;

VII. ações e quotas de sociedades simples e empresárias; X percentual do faturamento de empresa devedora;

VIII. pedras e metais preciosos;

IX. direitos aquisitivos derivados de promessa de compra e venda e de alienação fiduciária em garantia;

X. outros direitos.

§ 10 É prioritária a penhora em dinheiro, podendo o juiz, nas demais hipóteses, alterar a ordem prevista no caput de acordo com as circunstâncias do caso concreto.

§ 2o Para fins de substituição da penhora, equiparam-se a dinheiro a fiança bancária e o seguro garantia judicial, desde que em valor não inferior ao do débito constante da inicial, acrescido de trinta por cento.

§ 3ํ Na execução de crédito com garantia real, a penhora recairá sobre a coisa dada em garantia, e, se a coisa pertencer a terceiro garantidor, este também será intimado da penhora.

A ordem preferencial de bens a serem penhorados tem como objetivo garantir um melhor proveito ao credor, bem como um menor sacrifício ao executado.

De forma a atender aos princípios do resultado da execução (segundo o qual a execução deve ocorrer de forma mais proveitosa para o credor) e do menor sacrifício do executado (que determina que a execução não deve ir além do estritamente necessário para a satisfação do crédito - artigo 805 do (PC/15); a eleição dos bens penhoráveis não será arbitrária, nem para o oficial de justiça, nem para as partes da execução, estabelecendo o artigo 835 do CPC/153 uma preferência legal em favor de certos bens para realização da penhora (MARINONI, 2014, p.57)

Nesse sentido, torna-se claro que o Novo Código de Processo Civil de 2015, preocupou-se tanto com o exequente no que tange à liquidez dos títulos a serem penhorados, bem como com o executado no que se refere à uma menor dificuldade para que o mesmo possa cumprir com sua obrigação de satisfazer a dívida. Importa mencionar, ainda, que o executado possui o dever de cooperar com a penhora, principalmente na concordância dos bens a serem penhorados e, quando necessário, localização desses.

\subsection{O DEVER DE COOPERAÇÃO INERENTE AO EXECUTADO}


O dever de cooperação tem seu início na boa-fé objetiva das partes, tendo em vista esse ser um dos pressupostos necessários à realização de um processo. Pode-se dizer que a cooperação no caso da penhora de bens, relaciona-se com o executado ter o intuito de sanar a dívida e consequentemente resolver a lide que ali esteja instaurada.

A questão principal do dever de cooperação é a indicação dos bens por parte do devedor, ou seja, a demonstração de onde os bens passíveis de penhora bastantes para satisfação da dívida se encontram. Após leitura e compreensão do artigo 774 do NCPC/15 não restam dúvidas de que a não indicação dos bens passíveis de penhora é um ato atentatório à dignidade da justiça.

Art.774. Considera-se atentatória à dignidade da justiça a conduta comissiva ou omissiva do executado que:

I. frauda a execução;

II. se opõe maliciosamente à execução, empregando ardis e meios artificiosos;

III. dificulta ou embaraça a realização da penhora; IV - resiste injustificadamente às ordens judiciais;

IV. V - intimado, não indica ao juiz quais são e onde estão os bens sujeitos à penhora e os respectivos valores, nem exibe prova de sua propriedade e, se for o caso, certidão negativa de ônus.

Parágrafo único. Nos casos previstos neste artigo, o juiz fixará multa em montante não superior a vinte por cento do valor atualizado do débito em execução, a qual será revertida em proveito do exequente, exigível nos próprios autos do processo, sem prejuízo de outras sanções de natureza processual ou material.

As decisões advindas dos Tribunais seguem o mesmo posicionamento, veja-se:

AGRAVO DE INSTRUMENTO - FRAUDE A EXECUÇÃO - CPC ARTIGO 593, II ESTADO DE INSOLVÊNCIA - CARACTERIZAÇÃO - DEVER DO EXECUTADO DE INDICAR BENS PASSÍVEIS DE PENHORA - MODELO DE TUTELA JURISDICIONAL EXECUTIVA INSTITUÍDA PELA LEI 11.328/2005 QUE TRANSFERE PARA O DEVEDOR O DEVER DE DEMONSTRAR SUA SOLVÊNCIA, INDICANDO BENS PARA FAZER FRENTE À EXECUÇÃO - DEVER DE ASSIM PROCEDER SOB PENA DE MULTA - SILÊNCIO QUE DEVE SER TOMADO EM DESFAVOR DO EXECUTADO PRESUNÇÃO DE INSOLVÊNCIA NÃO ABALADA E QUE DEVE SER TOMADA EM FAVOR DO EXEQUENTE - INTELECÇÃO SISTEMÁTICA DO ARTIGO 652, § 3o DO CPC - RECURSO DE AGRAVO DE INSTRUMENTO

IMPROVIDO. Ao devedor incumbe o dever de indicar bens passíveis de penhora, sob pena de, assim não procedendo, ser compelido a tanto com aplicação de multa, ou se submeter à indicação feita pelo exeqüente que tem na ordem do artigo 655 mera indicação de preferências. Ao devedor, portanto, incumbe o ônus de descaracterizar a fraude à execução, no caso, demonstrando a sua solvabilidade, suportando, no silêncio, a ineficácia das alienações patrimoniais perpetradas no curso da execução. (TJ-SP AG: 1236611007 SP, Relator 
L.Fernando Nishi, Data de julgamento: 03/02/2009, 31ạ Câmara de Direito Privado, Data da Publicação: 17/02/2009)

Com isso, é clarividente que tanto a legislação, como as decisões dos Tribunais vão ao encontro da melhor satisfação para o credor, bem como buscam assegurar os princípios da celeridade e razoável duração do processo, com previsão expressa na Lei Maior em seu artigo 5o, inciso LXXVIII.

\subsection{MODIFICAÇÃO DA PENHORA}

Existe na legislação a possibilidade de modificação da penhora, trazendo a alternativa de alteração do bem penhorado, sendo possível pelas duas partes, através da previsão constante no art. 847, conferindo ao devedor pleitear a substituição, no prazo de 10 dias contados da intimação da penhora, tendo como condicionante comprovar a menor onerosidade ao próprio e não trazendo prejuízo ao credor seguindo o princípio da menor onerosidade à execução, sendo ônus do executado.

Art. 848. As partes poderão requerer a substituição da penhora se: I - ela não obedecer à ordem legal;

I. ela não incidir sobre os bens designados em lei, contrato ou ato judicial para o pagamento;

II. havendo bens no foro da execução, outros tiverem sido penhorados;

III. havendo bens livres, ela tiver recaído sobre bens já penhorados ou objeto de gravame;

IV. ela incidir sobre bens de baixa liquidez;

V. fracassar a tentativa de alienação judicial do bem; ou

VI. o executado não indicar o valor dos bens ou omitir qualquer das indicações previstas em lei.

Parágrafo único. A penhora pode ser substituída por fiança bancária ou por seguro garantia judicial, em valor não inferior ao do débito constante da inicial, acrescido de trinta por cento.

Faz-se a ressalva da possibilidade de uma substituição por fiança bancária ou por seguro garantia judicial em valor não inferior ao débito da inicial, acrescido por trinta por cento. Também será possível redução ou transferência de bem penhorado quando este sofrer alteração significativa no valor do mercado, como por exemplo implementos agrícolas que estão em elevação no mercado. Em caso de deferimento por parte do juiz, a outra parte é intimada para ser ouvida e com a conclusão da substituição o termo é lavrado.

\subsection{BENS IMPENHORÁVEIS}


A legislação relacionou alguns bens, sejam eles móveis ou imóveis que são insuscetíveis de penhora, ou seja, esse bens não podem sofrer nenhum tipo de restrição referente à penhora, não podendo também, consequentemente, o credor indicá-los e nem mesmo o oficial de justiça realizar a penhora dos mesmos. Essa previsão legal encontra-se nos artigos 832 e 833 do Código de Processo Civil, sendo válida a ressalva de que os bens de família também são considerados como impenhoráveis, conforme dispõe a Lei 8009/90.

Art. 832. Não estão sujeitos à execução os bens que a lei considera impenhoráveis ou inalienáveis.

Art. 833. São impenhoráveis:

I. os bens inalienáveis e os declarados, por ato voluntário, não sujeitos à execução;

II. os móveis, os pertences e as utilidades domésticas que guarnecem a residência do executado, salvo os de elevado valor ou os que ultrapassem as necessidades comuns correspondentes a um médio padrão de vida;

III. os vestuários, bem como os pertences de uso pessoal do executado, salvo se de elevado valor;

IV. os vencimentos, os subsídios, os soldos, os salários, as remunerações, os proventos de aposentadoria, as pensões, os pecúlios e os montepios, bem como as quantias recebidas por liberalidade de terceiro e destinadas ao sustento do devedor e de sua família, os ganhos de trabalhador autônomo e os honorários de profissional liberal, ressalvado o § 20 ;

V. os livros, as máquinas, as ferramentas, os utensílios, os instrumentos ou outros bens móveis necessários ou úteis ao exercício da profissão do executado;

VI. o seguro de vida;

VII. os materiais necessários para obras em andamento, salvo se essas forem penhoradas;

VIII. a pequena propriedade rural, assim definida em lei, desde que trabalhada pela família;

IX. os recursos públicos recebidos por instituições privadas para aplicação compulsória em educação, saúde ou assistência social;

X. a quantia depositada em caderneta de poupança, até o limite de 40 (quarenta) salários-mínimos;

XI. os recursos públicos do fundo partidário recebidos por partido político, nos termos da lei;

XII. os créditos oriundos de alienação de unidades imobiliárias, sob regime de incorporação imobiliária, vinculados à execução da obra. 
$\S 1$ 10 A impenhorabilidade não é oponível à execução de dívida relativa ao próprio bem, inclusive àquela contraída para sua aquisição.

$\S 2$ ㅇ O disposto nos incisos IV e X do caput não se aplica à hipótese de penhora para pagamento de prestação alimentícia, independentemente de sua origem, bem como às importâncias excedentes a 50 (cinquenta) salários-mínimos mensais, devendo a constrição observar o disposto no art. 528, § 8ㅇ , e no art. $529, \S 30$.

$\S$ 3o Incluem-se na impenhorabilidade prevista no inciso $V$ do caput os equipamentos, os implementos e as máquinas agrícolas pertencentes a pessoa física ou a empresa individual produtora rural, exceto quando tais bens tenham sido objeto de financiamento e estejam vinculados em garantia a negócio jurídico ou quando respondam por dívida de natureza alimentar, trabalhista ou previdenciária.

Em referência aos bens impenhoráveis por serem bens de família, a Lei no 8.009, de 29 de março de 1.990, dispõe expressamente em seu art. 1‥

Art.1‥ O imóvel residencial próprio do casal, ou da entidade familiar, é impenhorável e não responderá por qualquer tipo de dívida civil, comercial, fiscal, previdenciária ou de outra natureza, contraída pelos cônjuges ou pelos pais ou filhos que sejam seus proprietários e nele residam, salvo nas hipóteses previstas nesta lei.

Parágrafo único - A impenhorabilidade compreende o imóvel sobre o qual se assentam a construção, as plantações, as benfeitorias de qualquer natureza e todos os equipamentos, inclusive os de uso profissional, ou móveis que guarnecem a casa, desde que quitados.

Essa categorização de alguns bens como impenhoráveis, justifica-se no fato de que toda pessoa deve possuir um mínimo existencial, garantindo-se assim o princípio da dignidade da pessoa humana, que será amplamente abordado em tópico posterior.

A exceção existente nesse contexto, na verdade, é uma inovação que vem surgindo nas jurisprudências do Superior Tribunal de Justiça, e também nos demais Tribunais, no que tange à mitigação da regra da impenhorabilidade absoluta do salário, tornando-a relativa, desde que reste preservada a dignidade do de devedor e garantido o seu mínimo existencial.

EMENTA: PROCESSO CIVIL. AGRAVO DE INSTRUMENTO. EXECUÇÃO DE TÍTULO EXTRAJUDICIAL. PENHORA DE PARTE DO SALÁRIO DO DEVEDOR. MITIGAÇÃO. POSSIBILIDADE. DIGNIDADE DO DEVEDOR E DE SUA FAMÍLIA PRESERVADA. AGRAVO DE INSTRUMENTO PROVIDO. DECISÃO REFORMADA. 1.

A Corte Especial do STJ tem entendimento de que há possibilidade de mitigação da impenhorabilidade absoluta da verba salarial, desde que preservada a dignidade do devedor e observada a garantia de seu mínimo existencial. Precedentes: AgInt no REsp 1847503/PR e REsp 1705872/RJ. 2. Na espécie, o credor buscou bens do devedor para saldar a dívida, inclusive mediante pesquisa via BACENJUD, RENAJUD ERIDF e INFOJUD, sem sucesso, e, além disso, o processo tramita por mais de 10 (dez) anos, sem que se obtenha êxito na 
direção da satisfação do crédito. 2.1. Considerando-se que a penhora no percentual de $10 \%$ (dez por cento) do salário do devedor não tem o condão de comprometer a sobrevivência deste e de sua família, mantendo a dignidade destes, e que o atual entendimento firmado no âmbito do Superior Tribunal de Justiça admite a mitigação da impenhorabilidade absoluta de verba salarial, deve ser deferida a constrição

em tal patamar. 3. Agravo de instrumento provido. Decisão reformada. (TJDFT - A.I: 0748327-65.2020.8.07.0000, 2021).

Observa-se que a mitigação do salário não pode ser utilizada em qualquer caso, devendo-se sempre observar qual parcela do recebimento mensal do executado será bloqueada e, principalmente, se o referido bloqueio não irá prejudicar a subsistência do mesmo e de sua família, visando sempre a efetivação concreta do princípio da dignidade da pessoa humana.

\section{PRINCÍPIOS NORTEADORES DA CORRETA APLICAÇÃO DA PENHORA NO PROCESSO CIVIL}

A palavra princípio, comumente utilizada no mundo jurídico advém do latim principium (CARRAZA, 1999, p.30), possuindo como significado, origem, começo. Os princípios, de modo geral, encontram respaldo na Constituição da República Federativa do Brasil e devem ser utilizados em todos os tipos de processos judiciais, bem como na solução de conflitos extrajudiciais, na busca incessante de garantir os direitos de ambas as partes, da melhor e mais célere forma.

Existem vários princípios, tanto na Lei Maior, quanto nos demais códigos, deixando-se clara a ideia de que não há hierarquia entre os mesmos, conforme explana Vicente Paulo e Marcelo Alexandrino:

Ocorrendo conflito entre princípios constitucionais num caso concreto, deve ser arredada, de pronto, a idéia de existência de hierarquia entre eles, que autorizaria a aplicabilidade integral de um deles ("direito hierarquicamente superior"), aniquilando em sua totalidade o outro ("direito hierarquicamente inferior"). Se adotada essa orientação, estaríamos implicitamente propugnando a existência de princípios "absolutamente incompatíveis" dentro do texto da Lei Maior, o que resultaria em uma inadmissível destruição de sua unidade normativa (princípio da unidade da Constituição) $(2003, p .20)$.

A partir da constatação de que os princípios não possuem grau de hierarquia entre si, e que todos são de suma importância para a solução de conflitos, serão estudados adiante aqueles que mais se envolvem com o escopo social da presente pesquisa, ou seja, os que norteiam a devida aplicação e utilização do instituto da penhora.

\subsection{PRINCÍPIO DA DIGNIDADE DA PESSOA HUMANA}

O princípio da dignidade da pessoa humana encontra sua previsão legal no artigo 10 da CRFB/88, salientando que há uma amplificação em sua conceituação. 
Art. 1ㅇ A República Federativa do Brasil, formada pela união indissolúvel dos Estados e Municípios e do Distrito Federal, constitui-se em Estado Democrático de Direito e tem como fundamentos:

I. a soberania;

II. a cidadania;

III. a dignidade da pessoa humana;

IV. os valores sociais do trabalho e da livre iniciativa; V - o pluralismo político.

Parágrafo único. Todo o poder emana do povo, que o exerce por meio de representantes eleitos ou diretamente, nos termos desta Constituição.

Importante destacar que o princípio em comento visa garantir direitos para cada ser humano, de forma individual, analisando-se os valores intrínsecos de cada um. Ainda, em uma breve análise histórica vê-se com clareza que esse princípio surge com a intenção de minimizar situações degradantes e ofensivas ao ser humano. E, no processo civil, sua utilização é sempre averiguada de forma a causar o menor sacrifício possível ao devedor, garantindo ao mesmo tempo a satisfação da dívida para a pessoa do credor.

Temos por dignidade da pessoa humana a qualidade intrínseca e distintiva de cada ser humano que o faz merecedor do mesmo respeito e consideração por parte do Estado e da comunidade, implicando, neste sentido, um complexo de direitos e deveres fundamentais que assegurem a pessoa tanto contra todo e qualquer ato de cunho degradante e desumano, como venham a lhe garantir as condições existenciais mínimas para uma vida saudável, além de propiciar e promover sua participação ativa corresponsável nos destinos da própria existência e da vida em comunhão dos demais seres humanos. ( SARLET, 2001, p.60)

A menção que mais se importa fazer nesse momento da pesquisa é que o devedor, quando chega ao momento de ter seus bens penhorados, já passou por todo o devido processo legal, com seus direitos e garantias resguardados e protegidos pela legislação e princípios. E, ainda assim, por motivos válidos ou não, deixou de cumprir com a obrigação de pagar, o que consequentemente acarretou a possibilidade de execução de seus bens, deixando-se sempre a ressalva daqueles que são impenhoráveis.

Portanto, o princípio da dignidade da pessoa humana no Processo Civil é utilizado para garantir que a dívida seja satisfeita ao credor, mas que ao mesmo tempo não haja um sacrifício exacerbado para o devedor, no que se refere à condições de subsistência própria e da família.

Pode-se dizer que o princípio da dignidade da pessoa humana relaciona-se com o equilíbrio da relação processual, não podendo ferir a parte credora que cumpriu com todas as obrigações que lhe foram facultadas, mas também auxiliando para que a contraprestação, seja efetivada da forma menos 
danosa ao devedor, seguindo sempre a linha proposta pela Constituição Federal, qual seja, a correta efetivação do princípio aqui relacionado e garantia do mínimo existencial.

A dignidade da pessoa humana pode ser concebida pela qualidade intrínseca e distintiva que há de ser reconhecida em cada ser humano, no respeito por parte do Estado e da sociedade das prerrogativas que lhes são inerentes, assim, define-se por "um complexo de direitos e deveres fundamentais que assegurem à pessoa todo e qualquer ato de cunho degradante e desumano, como venham a Ihe garantir as condições existenciais mínimas para uma vida saudável" (SARLET, 2007, p.62)

Ainda, a fim de complementar o estudo dos princípios que mais asseguram a efetividade do instituto da penhora, falar-se-á sobre os princípios da isonomia e proporcionalidade que em muito se adequa ao presente artigo.

\subsection{PRINCÍPIO DA ISONOMIA}

O princípio da isonomia previsto na Constituição Federal de 1988, especificamente no artigo 5o e seus incisos demonstra que a Lei Maior traz expressamente a premissa de que todos são iguais perante a legislação.

Art. 5o Todos são iguais perante a lei, sem distinção de qualquer natureza, garantindo-se aos brasileiros e aos estrangeiros residentes no País a inviolabilidade do direito à vida, à liberdade, à igualdade, à segurança e à propriedade, nos termos seguintes: [...]

Em relação a esse princípio no Código de Processo Civil, o mesmo encontra sua previsão no artigo 7음 do referido diploma, tendo como máxima a ideia aristotélica de "tratar igualmente os iguais e desigualmente os desiguais, dando a cada um o que é seu", garantindo-se uma paridade entre as partes da relação processual.

Art. 70 É assegurada às partes paridade de tratamento em relação ao exercício de direitos e faculdades processuais, aos meios de defesa, aos ônus, aos deveres e à aplicação de sanções processuais, competindo ao juiz zelar pelo efetivo contraditório.

Nesse diapasão, menciona Alexy,

A assimetria entre a norma de tratamento igual e a norma de tratamento desigual tem como consequência a possibilidade de compreender o enunciado geral de igualdade como um princípio da igualdade, que prima facie exige um tratamento igual e que permite um tratamento desigual apenas se isso for justificado por princípios contrapostos. (2011,p.410).

Salienta-se que há a isonomia formal, constante no texto da lei, e a isonomia material que diz respeito às situações concretas, o que foi pontuado pelo NCPC em alguns de seus dispositivos, visto que a partir 
da leitura dos mesmos vê-se que a busca pela paridade e melhoria de condições para as partes é nítida, buscando a efetivação do princípio da isonomia juntamente com a dignidade da pessoa humana.

\begin{abstract}
A igualdade, com efeito, deve ser avaliada sob o seu aspecto substancial ou material. É necessário tratar os iguais de forma igual e os desiguais de forma desigual, na exata medida de suas desigualdades. Vale dizer: as pessoas ou as situações são iguais ou desiguais de modo relativo, ou seja, sob certos aspectos. Nesse contexto, a tendência do constitucionalismo contemporâneo tem sido a de não se limitar à enunciação de um postulado formal e abstrato de isonomia jurídica, mas sim de fixar nas Constituições medidas concretas e objetivas tendentes à aproximação social, política e econômica entre os jurisdicionados.
\end{abstract} (CASTRO, 1983, p.52)

A evolução da utilização do princípio em comento é constante, considerando que dia após dia, o legislador busca novas formas de garantir a tão falada igualdade, bem como os juízes aperfeiçoam seus entendimentos e decisões no mesmo sentido, deixando de lado a mera formalidade e passando para a materialidade das situações que acontecem no judiciário.

E o processo, para ser democrático, demanda contraditório e, sobretudo, igualdade substancial. É necessário, então, tratar-se os iguais de forma igual e os desiguais de forma desigual exatamente para ser afastado qualquer tipo de desigualdade. Desse modo, inclusive, o direito processual aproximar-se-á do direito substancial, permitindo que a vontade da lei seja atuada da forma mais exata possível. (HERTEL, 2006, p.10).

De acordo com a ideia de minimizar as dificuldades para as partes que compõem a lide, o julgador passa a ter um papel mais ativo, e, já consolidado pelo artigo 370 do CPC, referindo-se ao fato de que esse pode requerer às partes documentos que considere importantes para a decisão, relativizando os impactos tanto para o credor quanto para o devedor e finalmente garantindo a isonomia material.

\title{
3.3 PRINCÍPIO DA PROPORCIONALIDADE
}

A proporcionalidade deve acontecer tanto no plano abstrato, ou seja, no momento em que o legislador irá criar as leis com base no referido princípio, bem como no plano concreto, que é o momento em que o julgador irá utilizar os dispositivos legais existentes para fundamentar sua decisão.

Salienta-se que toda a atuação do julgador deve estar consolidada em lei, porém sabido que a legislação deixa brechas e é a partir disso que os princípios constitucionais, e os advindos dos demais códigos devem ser largamente utilizados a fim de sanar qualquer lacuna existente no texto legal, acarretando às partes um processo justo e pautado na boa-fé da utilização principiológica.

No processo de execução civil, o princípio da proporcionalidade deve ser visto como uma "justa medida", equilibrando a relação entre as partes, de modo a adequar o melhor meio para se alcançar o fim desejado. E nessa contextura o 
princípio da proporcionalidade irá aparecer como norma de calibragem, pois pode e deve ser empregado como critério para solucionar da melhor forma as colisões de direitos fundamentais e os choques de princípios instalados, harmonizando na medida em que se prestigia um e desatende o mínimo possível o outro princípio. (LIMA, 2006, p.11).

Na visão de Nery Júnior (2002, p.161) é estabelecido que o princípio da proporcionalidade pode ser denominado como lei de ponderação, devendo ser sopesados os interesses e direitos em jogo para que se alcance a solução concreta mais justa.

Um último adendo a se fazer no presente tópico é o fato do princípio da proporcionalidade possuir ligação aos demais princípios, mas, não dependência, tendo em vista que o mesmo é utilizado para coibir situações em que se coloca o mínimo existencial e a dignidade da pessoa humana fora dos trilhos, devendo sempre ser utilizado abstratamente pelo legislador e concretamento por aquele que irá proferir uma decisão na execução civil, fazendo-se sempre a ressalva dos bens impenhoráveis, bem como do mínimo necessário para subsistência própria do devedor e sua família, na busca pela melhor satisfação do credor e menor sacrifício ao devedor.

\section{A EFETIVAÇÃO DA PENHORA À LUZ DO PRINCÍPIO DA DIGNIDADE DA PESSOA HUMANA}

Como já mencionado em linhas anteriores, a penhora é o instituto utilizado para a satisfação de uma dívida, entre um credo e um devedor, na qual o devedor deixa de cumprir com suas obrigações e passa então a uma execução civil, sob o risco de expropriação de seus bens, deixando-se sempre clara a ressalva do rol de bens impenhoráveis, assim como o bem de família, previsto em Lei.

A questão principal é que há a possibilidade de uma penhora de bens que seja justa para ambas as partes da lide, de forma que não se tenha um sacrifício exacerbado por parte do devedor e que o credor não deixe de receber o que é seu por direito. Essa satisfação consciente e pautada na paridade advém do princípio da dignidade da pessoa humana, na garantia do mínimo existencial.

\subsection{ESCOPO SOCIAL DA PENHORA E SEUS EFEITOS}

O escopo da penhora é, em regra, a satisfação da dívida para o credor, garantindo seus direitos através da constrição e posterior expropriação dos bens do devedor. Ocorre que, em conformidade com os princípios constitucionais, importante relacionar o princípio nulla executio sine titulo, que conforme leciona Neves (2015) não há execução sem um título que a baseie. 
Essa premissa de existência de um título seja ele judicial ou extrajudicial serve para assegurar que o devedor não arque com obrigações além das devidas, bem como para afirmar que a dívida existe e que será paga através da execução civil mediante a penhora.

A partir da realização do processo de penhora surgem os efeitos no mundo jurídico, desde o plano abstrato, processual até a concretude material, insurgindo o cumprimento da obrigação por parte do executado e finalmente a satisfação da dívida para o credor.

Uma vez a penhora realizada, seja pelo cumprimento da ordem judicial, tanto quanto pela aceitação da nomeação de bem ofertado à penhora, esta incorre em efeitos jurídicos, tanto no plano do direito material, quanto no direito processual e, ainda, tanto para o exequente, quanto para o executado. (LEMOS, 2018, p.10).

Em análise a situação concreta das partes e ainda em observância ao princípios constitucionais e advindos dos demais códigos , o julgador decidirá conforme a legislação pátria, pautado na questão principiológica, na busca de efetivar o instituto da penhora, sem acarretar imenso sacrifício ao devedor.

No que tange aos efeitos posteriores à efetivação da penhora o papel de quem legisla, bem como de quem julga é exatamente fazer com que esses sejam os menos agressivos possíveis para ambas as partes da relação processual.

\subsection{A EFICÁCIA DO PRINCÍPIO DA DIGNIDADE DA PESSOA HUMANA NO ÂMBITO DA PENHORA NO PROCESSO DE EXECUÇÃO CIVIL}

A penhora no processo civil é o meio de garantir a satisfação do credor, a fim de que o mesmo receba aquilo que lhe é devido. Ocorre que, a designação dos bens a serem penhorados não pode acontecer de forma arbitrária, tendo em vista que através dos princípios constitucionais e da legislação pátria, faz-se necessário uma ponderação mediante a quitação da dívida e a garantia do mínimo existencial.

A ordem de penhora prevista no artigo 835 do Código de Processo Civil possui o condão de ordenar os bens que primeiro serão penhorados, considerando uma ordem benéfica tanto para o credor quanto para o devedor, mas, também, levando-se em conta a liquidez dos títulos.

Com as constantes mudanças existentes na sociedade e consequentemente no meio jurídico, surgese o instituto da penhora on-line, que é um meio do magistrado atingir as contas do executado e efetuar o bloqueio do saldo necessário para satisfação da dívida. O que importa mencionar, nesse 
momento, é que a penhora on-line está pautada no princípio da dignidade da pessoa humana e garante o mínimo existencial do devedor, pois quantias irrisórias não podem ser penhoradas.

Nas palavras de Nelson Nery Junior e Rosa Maria de Andrade Nery (2015):

Bloqueio de ativos financeiros e penhora on-line. Instituto já testados na justiça do trabalho, incorporados pela reforma imposta aos CPC/1973 em 2005/2006 à sistemática do processo civil como um todo, visam acelerar a busca de numerário do executado e, por consequência, o cumprimento da obrigação pendente.(2015, p. 1739)

Para melhor explicitar o referido instituto, Teresa Arruda Alvim Wambier (2016) menciona:

Nesse contexto não se pode deixar de mencionar o sistema BacenJud 2.0, criado por meio de convênio entre o Banco Central do Brasil e o Poder Judiciário. Por meio do BacenJud, os juízes, com senha previamente cadastrada, encaminham ordens judiciais de bloqueio, desbloqueio, transferência de valores, bem como requisições de informações, que são repassadas eletrônica e instantaneamente para os bancos, reduzindo enormemente o tempo de tramitação do pedido de informação ou bloqueio.(2016, p. 1298-1299).

Com isso, tendo como premissa máxima a correta utilização dos princípios advindos da Lei Maior, bem como dos demais códigos e considerando o instituto da penhora, sua ordem preferencial e os bens impenhoráveis vê-se que a questão geral e principiológica é o fato de utilizar a penhora juntamente com o princípio da dignidade da pessoa humana e o garantista mínimo existencial.

\section{CONSIDERAÇÕES FINAIS}

O desenvolvimento do presente artigo possibilitou a compreensão do instituto da penhora, mediante a conceituação do mesmo, com as informações referentes à suas modalidades, ordem de bens a serem penhorados, aqueles que não podem ser penhorados por constar restrição legal constante tanto no Código de Processo Civil como em demais leis.

O conceito de penhora pode ser dado como um ato pelo qual o magistrado define bens que serão entregues ao credor como forma de satisfazer uma dívida existente que não tenha sido adimplida pelo devedor.

Ainda, aprofundou-se o estudo em relação aos princípios constitucionais, que são encontrados na Lei Maior e também no Código de Processo Civil, sendo esses inerentes a todos os seres humanos, na busca de garantir direitos fundamentais do indivíduo. Dentre os princípios constitucionais, priorizouse o estudo do princípio da isonomia, encontrado no art.5 da CRFB/88 que pode ser definido como a medida necessária para igualar todos perante a lei, o princípio da proporcionalidade que busca um 
equilíbrio na relação processual e o princípio da dignidade da pessoa humana que é a base de todo o ordenamento jurídico.

Ao findar da análise, partindo para a problemática do artigo, soluciona-se a questão esclarecendo que a penhora de bens no processo de execução civil é um meio justo e eficaz de satisfação da dívida. Ocorre que, para que seja coerente para ambas as partes envolvidas na lide, a efetivação da penhora de bens deve pautar-se, principalmente, nos princípios da isonomia e proporcionalidade, preservando a dignidade da pessoa humana e a garantia do mínimo existencial.

Ressalta-se que o presente artigo não apenas trouxe conceitos, mas, também formas de aplicação eficazes que unem a funcionalidade do instituto da penhora com o princípio da dignidade da pessoa humana garantindo o mínimo existencial presente na Constituição Federal.

Oportuno mencionar ainda que, no que diz respeito à utilização da penhora à luz do princípio da dignidade humana, faz-se necessário que o legislador e o julgador tenham a visão principiológica necessária à aplicação no caso concreto.

O presente artigo respondeu o problema inicialmente proposto a partir da explanação do conceito de penhora e suas particularidades, juntamente com a abordagem feita em referência aos princípios, chegando a um determinante, qual seja, a necessidade de equilibrar a relação processual, pautandoa na boa-fé e também nos princípios, de forma a garantir a satisfação do credor com menor sacrifício do devedor.

Critica-se a falta de celeridade no curso do processo de execução civil no que se refere a penhora dos bens, e ainda, a procrastinação em equilibrar a relação processual de forma a ser eficaz para ambas as partes, tendo em vista que, com a devida utilização dos princípios constitucionais juntamente com o instituto da penhora de bens, a dívida seria satisfeita e a dívida sanada, sem situações desgastantes para os envolvidos na lide.

Conclui-se portanto que todos os objetivos foram alcançados e a problemática solucionada, de modo que o presente artigo traz possibilidades de efetivação dos princípios constitucionais, principalmente a dignidade da pessoa humana, com a garantia do mínimo existencial prevista na Lei Maior, durante toda a execução civil, valorizando as partes constantes na relação processual, dando celeridade ao ato e oportunizando tratamento igualitário a todos. 


\section{REFERÊNCIAS}

ABELHA, Marcelo. Manual de execução civil. 6. ed. rev. e atual. Rio de Janeiro: Forense, 2016.

ALEXY, Robert. Teoría de los derechos fundamentales. Madrid: Centro de Estudios Políticos y Constitucionales, 2001.

ARRUDA ALVIM WAMBIER, Teresa et. al. Primeiros comentários ao novo Código de Processo Civil: artigo por artigo. 2. ed. São Paulo: Ed. RT, 2016 [livro eletrônico].

BRASIL. Tribunal de Justiça do Distrito Federal e dos Territórios. Agravo de Instrumento 07483276520208070000/2021. Des. Alfeu Machado. Disponível em:

https://www.tjdft.jus.br/consultas/jurisprudencia/jurisprudencia-em-temas/jurisprudencia-emperguntas/direito-civil-e-processual-civil/penhora/e-possivel-a-relativizacao-da-re gra-deimpenhorabilidade-de-salario. Acesso em 03/11/2021.

BUENO, Cassio Scarpinella. Manual de direito processual civil : inteiramente estruturado à luz do novo CPC, de acordo com a Lei n. 13.256, de 4-2-2016 .2. ed. rev., atual. e ampl. São Paulo : Saraiva, 2016.

CARRAZA, Roque Antônio. Curso de direito constitucional tributário. 12.ed.São Paulo: Malheiros, 1999.

CASTRO, Carlos Roberto de Siqueira. O princípio da isonomia e a igualdade da mulher no direito constitucional. Rio de Janeiro: Forense, 1983.

DINAMARCO, Cândido Rangel. Instituições de direito processual civil. 3. ed. São Paulo: Malheiros Editores, 2009.

HERTEL, Daniel Roberto. Reflexos do princípio da isonomia no direito processual. Revista Brasileira de Ciências Criminais. São Paulo, vol. 55/2006, p.194-211, junho, 2006 [recurso eletrônico]. Disponível em: www.revistadostribunais.com.br. Acesso em:

$04 / 11 / 2021$

JÚNIOR, Nelson Nery. Princípios do Processo Civil na Constituição Federal. 7ạ ed. Ed. RT - 2002.

LEMOS, Vinicius Silva. A penhora e a sua função neutralizadora ao art. 139, IV, do CPC e as medidas atípicas.Revista Brasileira de Ciências Criminais. São Paulo, vol. 87/2018, p.123-148, março, 2018 [recurso eletrônico]. Disponível em: www.revistadostribunais.com.br. Acesso em: 04/11/2021.

LIMA, Márcio Kammer. O princípio da proporcionalidade na execução civil. Revista Brasileira de Ciências Criminais. São Paulo, vol. 848/2006, p.66-88, junho, 2006 [recurso eletrônico]. Disponível em: www.revistadostribunais.com.br. Acesso em: 04/11/2021.

MARINONI, Luiz Guilherme; ARENHART, Sérgio Cruz. Curso de processo civil. 6. ed. rev. e atual. São Paulo: Ed. RT, 2014.

NERY JUNIOR, Nelson; NERY, Rosa Maria de Andrade. Comentários ao Código de Processo Civil. São Paulo: Ed. RT, 2015. 
NEVES, Daniel Amorim Assumpção. Manual de Direito Processual Civil. Salvador: Juspodivm, 2016.

OLIVEIRA NETO, Olavo de et. al. Curso de direito processual civil. São Paulo: Editora Verbatim, 2018.

PAULO, Vicente; ALEXANDRINO, Marcelo. Direitos fundamentais: teoria geral e art. 5ㅇa CF/88. 2 ed. Rio de Janeiro: Impetus, 2003.

SAAD, Camila Chagas. A penhora de dinheiro e a penhora on-line como meio de garantia da efetividade da execução. Revista Brasileira de Ciências Criminais, São Paulo, vol. 289/2019, p. 191-224, março, 2019 [recurso eletrônico].Disponível em: www.revistadostribunais.com.br. Acesso em: 01/11/2021.

SARLET, Ingo Wolfgang. Dignidade da pessoa humana e direitos fundamentais na Constituição Federal de 1988. 5a ed. Porto Alegre: Livraria do advogado, 2007. 


\section{Capítulo 3}

\section{doi $10.37423 / 211205158$}

\section{COMO AS FAZENDAS COM PEQUENA ESCALA DE PRODUÇÃO UTILIZAM OS MÉTODOS DE INOVAÇÕES?}

José Francisco dos Reis Neto

Marlucy Ferreira Machagdo

Wesley Osvaldo Pradella Rodrigues

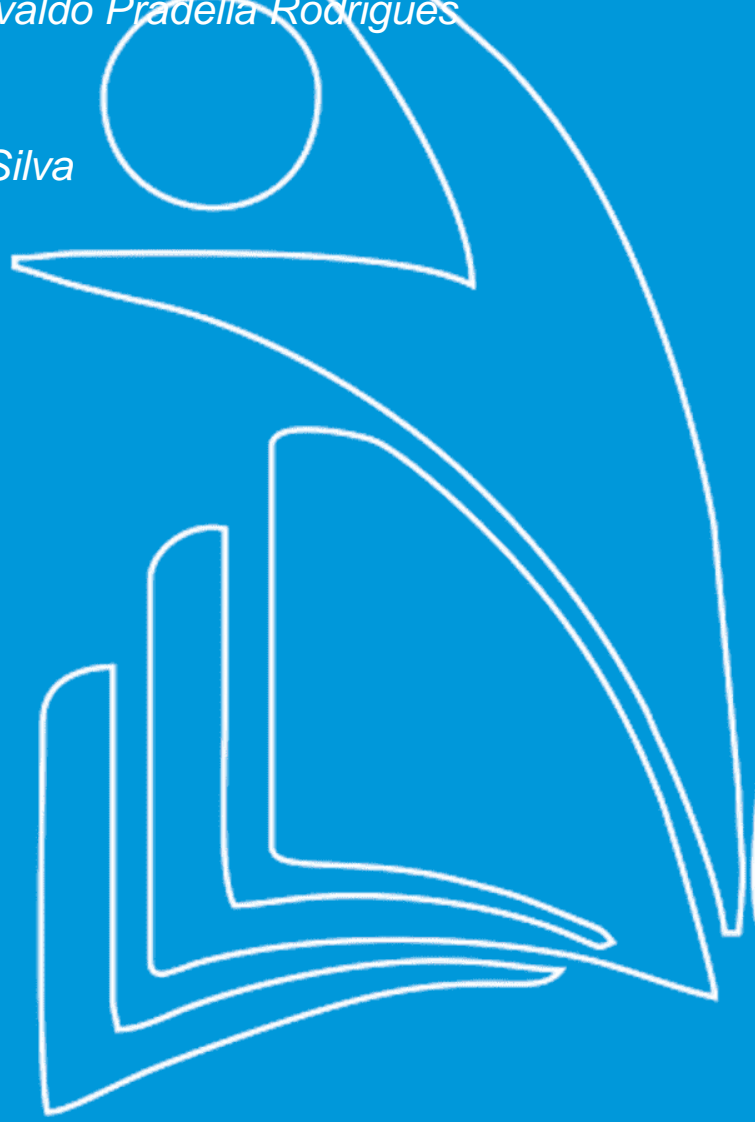

Universidade Anhanguera Uniderp

Faculdade Pitágoras

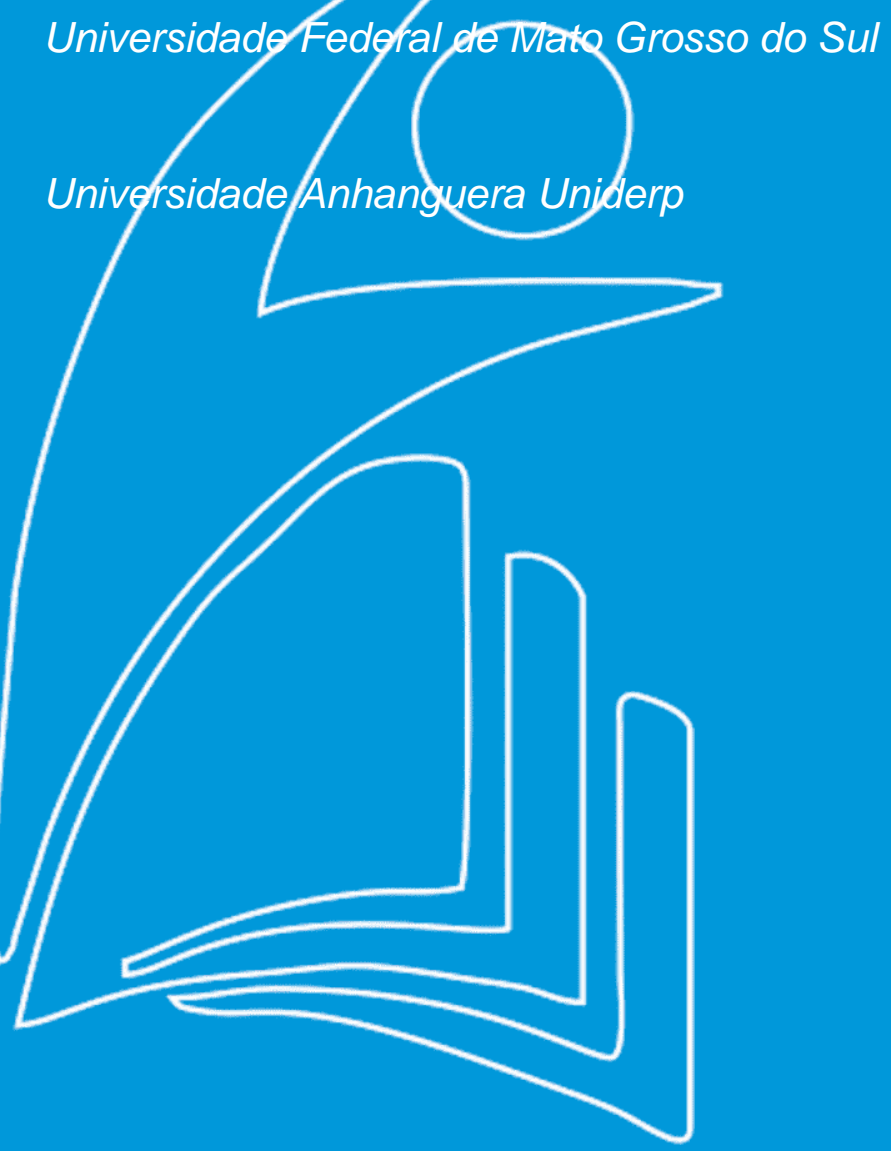


Resumo: Este trabalho buscou examinar os relacionamentos entre os processos de inovações e o desempenho financeiro das pequenas fazendas. A pesquisa foi realizada por meio de uma abordagem quantitativa, de natureza básica, com objetivos exploratórios e com procedimentos de levantamento de dados e informações primárias da população alvo, utilizando um questionário como instrumento de pesquisa. As entrevistas foram realizadas, face-a-face por 15 graduandos dos últimos semestres dos cursos de Agronomia e Veterinária, treinados e habilitados, durante os meses de abril e maio de 2018. Os resultados apontam que as pequenas fazendas com maiores áreas de produção agrícola e maior número de pessoas ocupadas procuram adotar uma gestão mais profissional, com a contratação de especialistas para isto. Ainda, as empresas com administração mais profissional utilizam mais de processos de inovações.

Palavras-chave: Empresas Rurais; Inovação; Gestão Profissional; Mato Grosso do Sul 


\section{INTRODUÇÃO}

Fazendas com produção em pequena escala representam 68,6\% da quantidade de imóveis rurais em Mato Grosso do Sul, ocupando 7,7\% da área rural na produção agrícola e pecuária (INCRA, 2014). Estes estabelecimentos rurais constituem, em grande parte, da forma de suprimentos de alimentos, com características essenciais em termos de segurança, oferta, acesso e estabilidade de mantimentos (FAO, 2008). Essas pequenas propriedades vivem com baixa renda, dentro de sistemas ecológicos muito frágeis, embora com grande potencial para mitigar as emissões de gases de efeito estufa, como consequência de sua baixa dependência de insumos externos. Além disso, essas fazendas representam um fator de viabilidade econômica, coesão social e redução da pobreza. O sistema praticado por essas pequenas propriedades rurais, muita das vezes produzindo bovinos e ovinos (carne e leite), com uma possível combinação de agricultura (frutas, hortaliças e grãos), com características agropecuárias, oferecem alto grau de resiliência de seus agroecossistemas e são um modelo predominante nos estados brasileiros (FAO, 2008).

O propósito deste estudo foi de examinar os relacionamentos entre os processos de inovações e o desempenho financeiro das pequenas fazendas.

\section{MATERIAL E MÉTODOS}

A pesquisa foi realizada por meio de uma abordagem quantitativa, de natureza básica, com objetivos exploratórios e com procedimentos de levantamento de dados e informações primárias da população alvo, utilizando um questionário como instrumento de pesquisa.

Para a coleta de dados foi empregado um questionário estruturado em partes, para que o entrevistado avaliasse as suas percepções em relação aos processos de inovação radical (IR) e incremental (II), o desempenho financeiro (DF), além das informações sociodemográficas e de estrutura da empresa rural. Para a mensuração dos itens da IR, II, e DF, foi empregado uma escala de Likert de concordância, com sete pontos, em que 1= Discordo Totalmente a 7= Concordo Totalmente. Todos os itens de medidas das variáveis latentes para IR, II e DF foram adotados de pesquisas e literaturas antecedentes e ajustados para o objeto da pesquisa. Para os itens de IR e II foram utilizados os itens propostos no trabalho de Jansen et al. (2006), e para o DF os itens propostos por Micheels e Gow (2012).

Para assegurar a confidencialidade das informações prestadas pelos empresários, não foi solicitado a sua identificação e os dados foram trabalhados de forma agregada, com resultados apresentados e configurados por grupos, não para os indivíduos. As entrevistas foram realizadas, face-a-face por 15 
graduandos dos últimos semestres dos cursos de Agronomia e Veterinária, treinados e habilitados, durante os meses de abril e maio de 2018. Os dados foram tratados e analisados com o emprego do software Sphinx v.5.

\section{RESULTADOS E DISCUSSÃO}

Da amostra de 250 empresas rurais, foram selecionadas 55 pequenas fazendas, com até 100 ha. A amostra apresentou a característica da predominância de 89,1\% homens, 34,5\% na faixa de idade de 45 a 54 anos, 40,0\% com nível de escolaridade médio, e 71,7\% declaram não ter feito nenhum curso específico para administrar a empresa rural (Tabela 1). As empresas rurais apresentaram uma área de 46 ha em média, com até 4 empregados e 2 pessoas da família na administração direta delas.

Empregando-se o teste $t$ para a verificação de independência entre amostras, estatística de comparação entre médias de diferentes grupos, relata-se que existem diferenças significativas a $\mathrm{p}<0,05$ para as áreas das fazendas, sendo que as fazendas com administração profissional (área= 94 ha) são maiores que as com administração familiar (área= 41 ha). Para as variáveis de quantidades de pessoas ocupadas, as empresas com administração familiar utilizam quatro pessoas e as com administração contratada com seis pessoas. Quanto a quantidade de familiares atuando na pequena fazenda, não existe diferenças significativas entre as empresas com administração familiar ou profissional.

Tabela 1 - Características Sociodemográficas da Amostra de 55 Pequenas Empresas Rurais

\begin{tabular}{|c|c|c|c|c|}
\hline & & \multicolumn{3}{|c|}{$\begin{array}{l}\text { A Fazenda é administrada pela família ou por } \\
\text { profissional contratado? (em \%) }\end{array}$} \\
\hline & & Família & Profissional & Total \\
\hline \multirow[t]{2}{*}{ Sexo } & Feminino & 12,0 & 0,0 & 10,9 \\
\hline & Masculino & 88,0 & 100,0 & 89,1 \\
\hline \multirow[t]{5}{*}{ Faixa de idade (em anos) } & Até 24 & 4,0 & 0,0 & 3,6 \\
\hline & 25 a 34 & 10,0 & 20,0 & 10,9 \\
\hline & 35 a 44 & 22,0 & 20,0 & 21,8 \\
\hline & 45 a 54 & 34,0 & 40,0 & 34,5 \\
\hline & 55 e mais & 30,0 & 20,0 & 29,1 \\
\hline \multirow[t]{4}{*}{ Nível de escolaridade } & Fundamental & 36,0 & 0,0 & 32,7 \\
\hline & Médio & 42,0 & 20,0 & 40,0 \\
\hline & Superior & 18,0 & 80,0 & 23,6 \\
\hline & Pós Graduado & 4,0 & 0,0 & 3,6 \\
\hline \multirow{7}{*}{$\begin{array}{l}\text { Curso específico para } \\
\text { administrar a Fazenda, que } \\
\text { o respondente fez }\end{array}$} & Técnico agropecuário & 8,3 & 20,0 & 9,4 \\
\hline & Administração & 0,0 & 40,0 & 3,8 \\
\hline & Agronomia & 0,0 & 20,0 & 1,9 \\
\hline & Economia & 0,0 & 0,0 & 0,0 \\
\hline & Veterinária & 4,2 & 0,0 & 3,8 \\
\hline & Zootecnia & 2,1 & 0,0 & 1,9 \\
\hline & Outros & 8,3 & 0,0 & 7,5 \\
\hline
\end{tabular}


Fonte: dados da pesquisa.

Não fez

77,1

20,0

71,7

A tabela 2 fornece a indicação das estatísticas descritivas das variáveis latentes, dos itens que compõem as escalas de medidas e dos coeficientes de confiabilidades do alfa de Cronbach, que avaliam a consistência da escala inteira da variável latente. Valores do alfa de Cronbach maiores que 0,7 indicam a aceitação da consistência e fornece a possibilidade de se analisar as variáveis latentes como unidimensionais.

Tabela 2 - Alfa de Cronbach, Médias e Desvios Padrões das variáveis latentes e itens

\begin{tabular}{|c|c|c|}
\hline Variáveis latentes e itens & Média & $\begin{array}{l}\text { Desvio } \\
\text { padrão }\end{array}$ \\
\hline Inovação Radical - IR (alfa=0,885) & 4,5 & 1,4 \\
\hline Aceitamos demandas que vão além dos produtos e serviços existentes. & 3,6 & 2,1 \\
\hline Experimentamos novidades que são oferecidos em nosso setor. & 4,6 & 1,8 \\
\hline Buscamos introduzir novas tecnologias. & 4,6 & 2,0 \\
\hline Utilizamos sempre de novas oportunidades, em novos mercados. & 4,6 & 1,9 \\
\hline Procuramos novos clientes, em novos mercados. & 4,9 & 2,0 \\
\hline Inovação Incremental - II (alfa=0,935) & 5,3 & 1,4 \\
\hline Aperfeiçoamos, continuamente, o fornecimento de produtos. & 5,1 & 1,9 \\
\hline $\begin{array}{l}\text { Implementamos, regularmente, pequenas adaptações nos nossos processos de } \\
\text { produção. }\end{array}$ & 5,2 & 1,8 \\
\hline Melhoramos a eficiência na produção dos nossos produtos. & 5,5 & 1,6 \\
\hline Aumentamos a produtividade de produtos. & 5,4 & 1,6 \\
\hline Reduzimos os custos dos processos internos. & 5,5 & 1,5 \\
\hline Mudamos as rotinas de trabalho e operações de produção sempre que necessário. & 5,3 & 1,8 \\
\hline Desempenho Financeiro - DF (alfa $=0,802)$ & 3,9 & 1,2 \\
\hline Ficamos muito satisfeitos com o desempenho geral. & 4,3 & 1,6 \\
\hline $\begin{array}{l}\text { Os preços que recebemos por nossos produtos foram mais altos que os dos nossos } \\
\text { concorrentes. }\end{array}$ & 3,4 & 1,9 \\
\hline O desempenho geral excedeu o dos nossos principais concorrentes. & 3,5 & 1,9 \\
\hline
\end{tabular}

Fonte: dados da pesquisa.

Para avaliar se existem diferenças significativas a $p<0,05$ entre as variáveis latentes $D F$, IR e II em relação a forma de administração da pequena fazenda, foi utilizado a técnica estatística de estimação de amostras independentes pelo teste t. Os resultados são indicados na tabela 3.

Tabela 3 - Comparação de amostras independentes pelo teste $t$

\begin{tabular}{lcccc}
\hline & \multicolumn{3}{c}{ A Fazenda é administrada pela família ou por profissional? } \\
\cline { 2 - 5 } & \multicolumn{3}{c}{ Família } & \multicolumn{2}{c}{ Profissional } \\
\cline { 2 - 5 } & Média & Desvio padrão & Média & Desvio padrão \\
\hline Desempenho Financeiro - DF & $4,0_{a}$ & 1,1 & $2,9 \mathrm{~b}$ & 1,4 \\
\hline Inovação Radical - IR & $4,4_{\mathrm{a}}$ & 1,4 & $5,0_{\mathrm{a}}$ & 0,6 \\
\hline Inovação Incremental - II & $5,2_{\mathrm{a}}$ & 1,3 & $6,7_{\mathrm{b}}$ & 0,4 \\
\hline
\end{tabular}

Nota: os valores na mesma linha que não compartilham o mesmo subscrito são bastante diferentes em $p<0,05$ no teste de igualdade para médias de colunas. Os testes consideram variâncias iguais.

Fonte: dados da pesquisa 
Os resultados indicam que a percepção do DF é significativamente diferente e maior para as empresas com administração familiar, em relação à administração profissional. No entanto, a relação entre os processos de inovações, a IR não tem diferença entre as duas formas de administração. Porém, a II tem percepções diferentes e a empresa com administração profissional relata aproveitar mais das melhorias e adaptações produtivas e de gestão em analogia às empresas com administração familiar. Pode-se inferir que as empresas mais familiares têm percepções mais sentimentais com o negócio, utilizando as tecnologias e gestão mais tradicionais.

\section{CONCLUSÃO}

Conclui-se que as pequenas fazendas com maiores áreas de produção agrícola e maior número de pessoas ocupadas procuram adotar uma gestão mais profissional, com a contratação de especialistas para isto. Ainda, as empresas com administração mais profissional utilizam mais de processos de inovações.

\section{AGRADECIMENTOS}

Os autores agradecem a FUNADESP pela oportunidade e financiamento da bolsa de iniciação científica. À UNIDERP pela cessão de suas instalações e equipamentos para a condução da pesquisa, aos cursos de Agronomia e Medicina Veterinária pela ajuda na coleta de dados primários junto aos empresários rurais. Em especial ao Programa de Mestrado em Produção e Gestão Agroindustrial que facilitou os estudos, as orientações e a colaboração do seu corpo docente e discente para esta pesquisa. 


\section{REFERÊNCIAS}

FAO (Food and Agriculture Organization of the United Nation). Ayudando a Desarrollar una Ganadería Sustentable en Latinoamérica y el Caribe: Lecciones a Partir de Casos Exitosos; Organización de las Naciones Unidas Para la Agricultura y Alimentación: Santiago, Chile; Oficina Regional Para América Latina y el Caribe: Rome, Italy, 2008.

INCRA (Instituto Nacional de Colonização e Reforma Agrária). Cadastro de Imóveis Rurais de Mato Grosso do Sul. Brasília: INCRA, 2014. Disponível em:

http://www.incra.gov.br/sites/default/files/uploads/estrutura-fundiaria/estat-sticas-de-im-veisrurais-/cadastro_imoveis_rurais_ms_geral_pub_e_priv.pdf. Acessado em 14 de mai de 2018.

JANSEN, J. J.; VAN DEN BOSCH, F. A.; VOLBERDA, H. W. Exploratory innovation, exploitative innovation, and performance: Effects of organizational antecedents and environmental moderators. Management Science, v. 52, n.11, p. 1661-1674, 2006.

MICHEELS, E. T.; GOW, H. R. The value of positional advantage for agricultural SMEs. Small Enterprise Research, v. 19, n. 2, p. 54-73, 2012. 


\section{Capítulo 4}

\section{doi $10.37423 / 220105192$}

\section{QUATRO DIAS DE REBELIÃO, COVID-19 E VACINAÇÃO:DO FICCIONAL AO FATUAL}
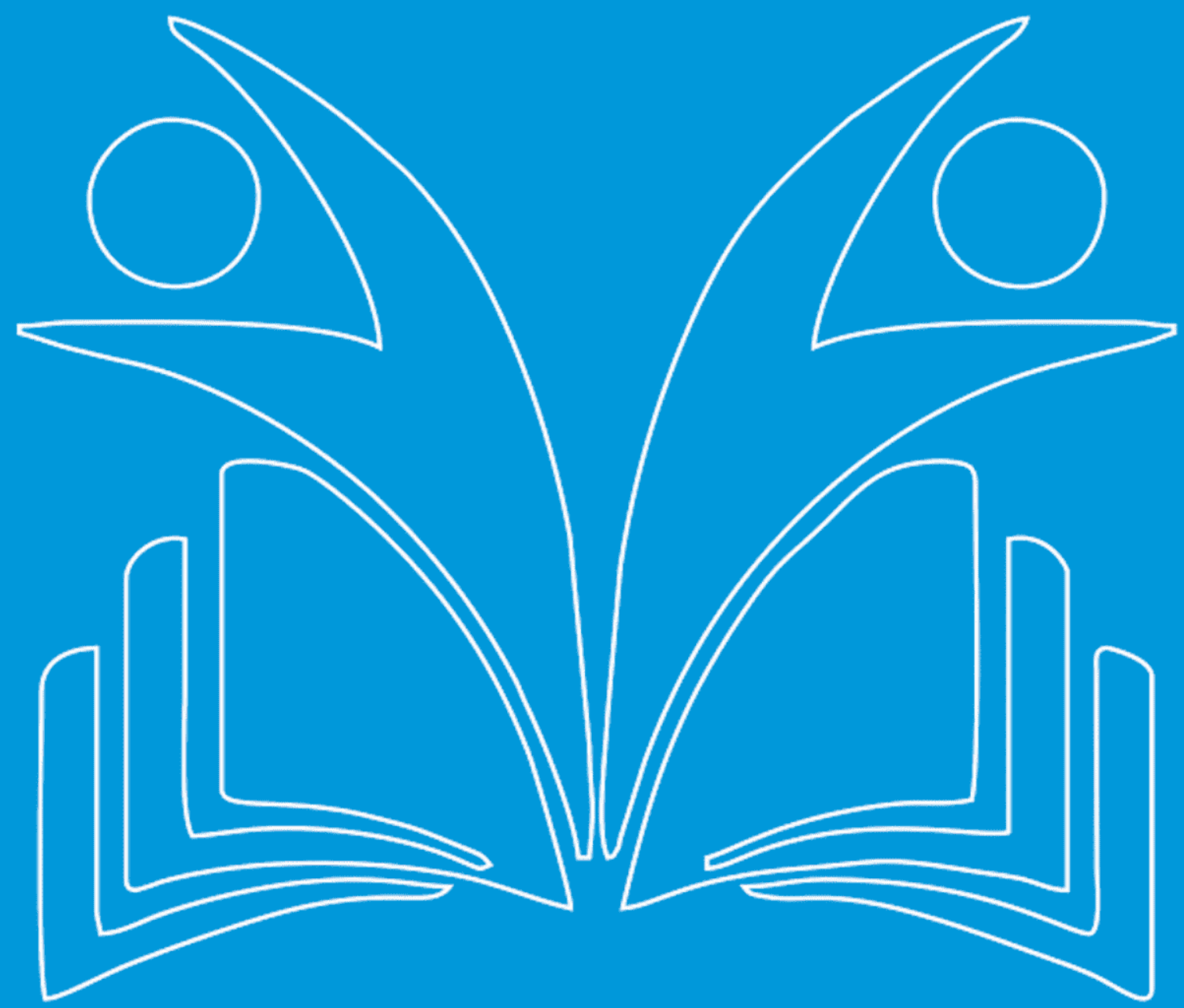
Resumo: Este estudo tem como ponto de partida o breve romance infanto-juvenil Quatro Dias de Rebelião (1977), de Joel Rufino dos Santos, que ficcionaliza o episódio histórico conhecido como "A revolta da Vacina"(1904), ocorrido no Rio de Janeiro durante o governo do ex-presidente Rodrigues Alves, usando como aporte teórico o livro A Revolução das Massas, de José Ortega Y Gasset (2013) e a questão da vacinação contra o Coronavírus no Brasil, que de modo diverso açodou suas próprias rebeliões contra o governo Jair Bolsonaro em 2021. Assim, chego à conclusão de que por trás de toda rebelião, seja ela social, cultural, religiosa, étnica, classista ou de gênero, existe uma ideologia política que a subjaz e que desagua sempre em mudança social, em um novo modo de ser. Concluo, como Gasset, que das massas brotam dois tipos de homens distintos: O homem médio, que se contenta em seguir a corrente, que despreza a tradição, é desprovido de senso histórico, não tem grandes aspirações e espera que o Estado resolva todos os seus problemas. De outro lado existe o homem nobre de postura, com forma de ser. Tem senso histórico, respeita a tradição, as conquistas de seus antepassados. Possui senso de dever, honra suas responsabilidades. Não espera que o Estado resolva seus problemas, não entrega seu destino nas mãos do Estado. É deste homem que suscita a ordem, a paz e o amor que o mundo caótico em que vivemos precisa; precisamos de segurança, equilíbrio, espírito fraterno e cooperação entre os seres vivos do planeta.

Palavras-chave: Pandemia; Quatro dias de Rebelião; vacinação; covid-19. 


\section{INTRODUÇÃO}

Quatro Dias de Rebelião é um breve romance histórico escrito na década de 1970 para o público infanto-juvenil por Joel Rufino dos Santos (1941-2015), historiador, escritor e intelectual afrobrasileiro, que narra o episódio da revolta contra a vacina obrigatória, evento acontecido durante a Primeira República. Por quatro dias, em novembro de 1904, a população pobre do Rio de Janeiro tomou conta da cidade, surrando vacinadores, invadindo prédios do governo, destruindo os lampiões da iluminação pública e as obras da "nova avenida". No quarto dia, políticos de oposição e militares apoiadores do presidente anterior, Floriano Peixoto, tentaram valer-se da rebelião popular para derrubar Rodrigues Alves, então presidente do Brasil, não conseguindo seu intento porque a insurreição das ruas extinguiu-se tão rápido quanto fogo de palha. No fundo, a vacina obrigatória havia sido um simples pretexto, a gota d'água para queixas mais antigas e prementes: As ruas estavam repletas de desempregados e desabrigados, enquanto a política monetária do presidente anterior provocava recessão comercial e industrial.

O próprio autor escreve, a título de prefácio, uma "necessária advertência" ao seu leitor sobre a hermenêutica da sua narrativa:

Esta história foi escrita para jovens leitores. Não foi completamente inventada. Rodrigues Alves, Silva Piragibe, Manduca, Beiço de Prata, Oswaldo Cruz, Lima Sobrinho, Galeguinho da Saúde, existiram de verdade. Nunca disseram, talvez, as palavras que eu os fiz dizer. Se alguém vivo é responsável pela memória deles, perdoe. 0 processo literário a que se atribuem palavras e gestos irreais a pessoas reais é velho e consagrado. Rosemblim, Closete, Nero, a Rainha dos Carapicuis, Marreta, Raul Perneira, Capitão Atlas, Mr. Walter L. Cawsert - toda essa gente foi inventada. Poderiam ter existido. Mas não existiram... (SANTOS, 1992, p.7).

E assim Joel Rufino segue esclarecendo que havia alterado também, "ligeiramente", alguns fatos históricos, apesar do respeito à verdade história. E dá como exemplo a Rua da Pouca Vergonha, que atualmente é a rua do Senado. Analogia mais adequada não poderia haver. Ele esclarece que tal logradouro não poderia, geograficamente falando, ficar ao pé do Morro da Mortona, fazendo esquina com a Camerino, mas que a troca "não prejudica nada nem ninguém" (p.7). É que ele gostara demais do nome - Rua da Pouca Vergonha - para não o usar - (e confesso que eu também). De resto, acrescenta: "contei o caso como o caso foi". Rio de Janeiro, 10 Jan. 1977. JOEL RUFINO DOS SANTOS (Idem, p.7).

Para melhor contextualizar o episódio histórico, fazem-se necessários alguns comentários sobre o governo de Rodrigues Alves e a revolta da vacina. O presidente foi beneficiado por uma fase de 
razoável estabilidade econômica. O boom da exportação de borracha da Amazônia e a possibilidade de contar com a ajuda de capital estrangeiro fez com que ele adotasse uma política de modernização, voltada para a reurbanização de áreas públicas que se encontravam em situação de degradação. Capital do país naquela época, a cidade do Rio de Janeiro foi o alvo principal desse projeto modernizador. No início do século XX o Rio era uma área urbana decadente. $\mathrm{O}$ acúmulo de lixo e a sujeira das ruas nas zonas periféricas e centrais atraía insetos e ratos que transmitiam doenças fatais como a febre-amarela, a varíola e a peste bubônica, resultando na morte de milhares de pessoas anualmente. As vielas, os becos e as ruas mal iluminadas tornavam a cidade desolada e bastante perigosa durante a noite. Foi preciso, então, sanear a cidade a partir da realização de obras públicas, da limpeza e do combate às doenças. O objetivo almejado pelo governo de modernização urbana da capital federal recebeu amplo apoio e respaldo do prefeito da cidade, Pereira Passos, mas a forma como foi realizada gerou revolta e protestos populares, abrindo a primeira crise política do governo de Rodrigues Alves. A reconstrução, a limpeza e o embelezamento da cidade foram feitos às custas das camadas pobres da população. Efetuando desapropriações desordenadas, as habitações populares (casebres e cortiços) foram postas abaixo para o alargamento das ruas, avenidas e construções de praças públicas. Os pobres foram empurrados para os morros e áreas periféricas da cidade, dando origem às favelas que existem até hoje. A valorização das novas áreas gerou uma grande especulação imobiliária, prejudicando também as camadas sociais da classe média.

Entretanto, foi o problema da saúde pública que desencadeou revoltas populares que, por sua vez, geraram uma grave crise política. O combate às doenças foi liderado pelo médico sanitarista Osvaldo Cruz. Estudioso das doenças tropicais, Osvaldo Cruz conseguiu que o governo decretasse a Lei da Vacina Obrigatória, que forçava toda a população a se vacinar para proteger-se das doenças epidêmicas. Os agentes de saúde pública efetuavam despejos e agressões para obrigar os populares a tomarem a vacina. O povo, revoltado, foi para as ruas e enfrentou a polícia num movimento que ficou conhecido como a Revolta da Vacina. Aproveitando-se da insatisfação popular, alguns militares florianistas, opositores de Rodrigues Alves, tentaram derrubá-lo do governo através de um golpe, liderado por Lauro Sodré ${ }^{1}$. Contudo, o governo reagiu rapidamente, decretando estado de sítio. Em seguida, organizou tropas militares de São Paulo e Minas Gerais, perseguiu e reprimiu todos os revoltosos.

Esta narração ficcionalizada de um fato real serve de pano de fundo para que a minha crítica comparatista possa trabalhar no sentido de unir o fato histórico, a ficção e a realidade atual sob o 
prisma de um catalisador comum, o vírus letal chamado Covid-19 que atualmente devasta a população mundial, as pestes que assolaram muitas cidades do mundo, representadas no romance de Santos pelo Rio de Janeiro no início dos anos 1900 e a questão da vacina, que, guardadas as devidas proporções, na obra e na vida real originaram suas revoltas de fundo político, demonstrando que a literatura não existe in isolatio; que ela exerce um papel social inestimável quando se trata de replicar os males sociais e provocar mudanças de comportamento na população.

Dentro desta perspectiva da literatura comprada, a maior provocação que se apresenta hoje ao comparatista é o desafio de recortar campos de saberes de tal forma que ele, como cientista das ciências humanas, responda às questões do lugar de onde fala e do assunto sobre o qual deveria versar. A este respeito Paulo Sérgio Nolasco dos Santos (2011) nos adverte que

O comparatista, o professor de Literatura Comparada hoje, não deve desconhecer a bibliografia constitutiva de um formidável compêndio e "cânone" que se foi avolumando em torno do assunto, onde muita tinta se fez correr, particularmente pela dinamicidade, mobilidade e volatilidade que sempre pautou a atividade comparatista desde os seus primórdios, nos escritos de Goethe e Mme. de Stäel, seja nas futuras formulações mais conhecidas como "textos fundadores. (WEINHARDT \& CARDOZO,2011, pp.273-4)

Sendo assim, já que o universo do discurso da Literatura Comparada é "de uma autofagia constante" (NOLASCO \& ALVES, 2013), proponho-me a investigar os assuntos apontados tentando alcançar a amplitude histórica que eles suscitam, uma vez que a ciclicidade da história o permite, e fixá-los ao aspecto teórico-crítico que melhor se me apresenta no momento, que é a teoria da rebelião das massas do filósofo espanhol José Ortega Y Gasset (2013), que mesmo tendo sido produzida na primeira metade do século XX me parece absurdamente atual e adequada ao meu propósito comparatista.

As revoltas que vêm se instaurando no Brasil do século XXI também têm como arrimo a questão da vacinação, desta vez contra o Coronavírus, ou Covid-19, pandemia altamente letal supostamente originada no Sul da China que se espalhou pelo mundo e vem ceifando milhões de vidas em todo o planeta desde o final de 2019. Por diversos meses, o governo do presidente Jair Bolsonaro, iniciado em Janeiro do mesmo ano, insistiu em um discurso contra a vacina da Covid-19 e colocou obstáculos para a assinatura de contratos para a aquisição do imunizante. Como uma réplica da história ficcionalizada de Santos, apoiadores da presidente anterior, Dilma Rousseff ${ }^{2}$ e do vice-presidente que a substituiu após o impeachment, Michel Temer, tentaram valer-se das rebeliões populares para derrubar Jair Bolsonaro, usando o imbróglio da vacina como pano de fundo para outras insatisfações contra o seu governo. 
Quando foi lançado o consórcio Covax-Facility, liderado pela Organização Mundial de Saúde (OMS), o presidente optou pela cota mínima de doses, que daria para imunizar apenas $10 \%$ da população brasileira. Em julho de 2020 firmou um acordo com a AstraZeneca para a produção de vacina pela Fiocruz e depois de idas e vindas, assinou contrato em janeiro de 2021 para a aquisição da CoronaVac, desenvolvida pelo Instituto Butantan. Em seguida, foram compradas doses de mais três fabricantes: Pfizer, Janssen e Sputnik. O Ministério da Saúde começou a discutir a negociação de outras duas vacinas, Covaxin e CanSino, mas as tentativas não avançaram por motivos diversos, havendo por fim insinuações de prevaricação e corrupção por parte da equipe do governo na compra do imunizante, enquanto a esquerda orquestrava manifestações em diversas capitais do país taxando o chefe de Estado de negacionista e genocida.

No dia 27 de abril de 2021, o Senado instalou uma comissão parlamentar de inquérito para apurar eventuais irregularidades na condução da pandemia. Após seis meses de audiências, oitivas, acusações e mudanças de foco das investigações, a CPI da Covid aprovou no dia 26 de outubro de 2021 o relatório final do senador Renan Calheiros (MDB-AL) sobre a maior tragédia sanitária da história do Brasil. De acordo com o site $\mathrm{G}^{3}{ }^{3}$, com a aprovação do relatório, a comissão de inquérito pede o indiciamento de 78 pessoas e duas empresas. O relatório aprovado pelos senadores tem 1.289 páginas e responsabiliza o presidente Jair Bolsonaro por considerar que ele cometeu pelo menos nove crimes. Também houve a inclusão de um pedido para que a advocacia do Senado acione o Supremo Tribunal Federal e a Procuradoria-Geral da República para promoverem a responsabilização de Bolsonaro por "campanha antivacina". O relator Renan Calheiros acusa o presidente de nove crimes: epidemia com resultado morte; infração de medida sanitária preventiva; charlatanismo; incitação ao crime; falsificação de documento particular; emprego irregular de verbas públicas; prevaricação ; crimes contra a humanidade e crimes de responsabilidade (violação de direito social e incompatibilidade com dignidade, honra e decoro do cargo) embora não consiga indiciá-lo por corrupção, motivo do impeachment do governo esquerdista antecessor e leitmotiv da campanha eleitoral que se avizinha para as eleições presidenciais de 2022.

Como Paulo Sérgio Nolasco dos Santos (2012) pertinentemente observa, os discursos sobre a literatura movimentam-se hoje, num contexto em que os conceitos e as noções que se tem sobre esse território, não provêm apenas dela mesma, mas de outros discursos das ciências humanas, quais sejam os trânsitos entre os saberes, a diluição das fronteiras e a interdisciplinaridade, por exemplo. São termos que refletem uma diversidade de interesses e a insistência em uma perspectiva teórica 
interpretativa que reserva um deslocamento, onde predomina a inversão de valores e hierarquias. Forma-se aí um paradigma em que o olhar do pesquisador vai se renovando em função do recorte sociocultural. Assim, a atividade crítica corrobora a pesquisa na medida em que o campo literário se articula com outras disciplinas, como a etnologia, a filosofia, a sociologia, o marxismo, a psicanálise, a teoria da escrita e do texto, contribuam para o avanço das práticas pós-estruturalistas, como os estudos pós-coloniais e os culturais, como é o caso deste trabalho.

Partindo de "verdades" comuns como os fatos históricos aqui apresentados, deparei-me com o intenso desafio de revisá-las, ou seria o mesmo que reconhecer, na prática, um recorte transdisciplinar e transdiscursivo para o qual os avanços teórico-metodológicos da Literatura Comparada já contribuem, assim como os Estudos Culturais complementam atualmente o campo da pesquisa. Sendo assim, o procedimento comparatista fruiu baseado em suas múltiplas variações, buscando validação pela formulação de novas perguntas, o que traduz a essência de se enfrentar a aventura da contemporaneidade.

Para mim, particularmente, esta aventura parte de como o homem pós-moderno, no sentido que lhe atribui Gasset, se comporta diante de certos adventos com que se depara em sua jornada impetuosa pelas sendas desses "tempos líquidos" defendidos pelo sociólogo polonês Zygmunt Bauman (2007), que diz respeito a uma nova época em que as relações sociais, econômicas e de produção são frágeis, fugazes e maleáveis como os líquidos e que se tonou tão cara aos estudos culturais pela fluidez e esgarçamento entre as fronteiras. Em A Rebelião das Massas Gasset nos diz que

A missão do chamado "intelectual" é, em certo modo, oposta à do político. A obra intelectual aspira, com frequência baldada, a esclarecer um pouco as coisas, enquanto a do político costuma, pelo contrário, consistir em confundilas mais do que estavam. Ser da esquerda é, como ser da direita, uma das infinitas maneiras que o homem pode escolher para ser imbecil: ambas, com efeito, são formas da hemiplegia moral. Ademais, a persistência destes qualificativos contribui não pouco a falsificar mais ainda a "realidade" do presente, já fala de per si, porque se encrespou o crespo das experiências políticas a que respondem, como o demonstra o fato de que hoje as direitas prometem revoluções e as esquerdas propõem tirania. (GASSET, 2013, p.29)

Para o filósofo, a absorção de todas as coisas e de todo o homem pela política, é a mesma coisa que o fenômeno de rebelião das massas que ele descreve: a massa em rebeldia perdeu toda a capacidade de religião e de conhecimento. Não pode ter como conteúdo mais que uma política exacerbada, doentia, fora de si, que pretende suplantar o conhecimento, a religião, a sabedoria — enfim, as únicas coisas que estão aptas a ocupar o centro da mente humana. Segundo ele, a política despoja o homem de solidão e de intimidade e, por isso, uma das técnicas que se usam para socializá-lo é a prédica do 


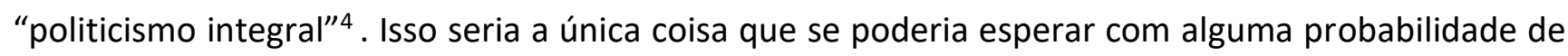
solução do tremendo problema que as massas atuais discutem. Uma vez que nos apercebemos bem de como é esse tipo humano hoje dominante e que Gasset chama de "homem-massa", acontecem os questionamentos mais fecundos e patéticos: Podemos melhorar este tipo de homem? ou seja: os inúmeros defeitos nele existentes, tão graves que se não os erradicamos de modo implacável produzirão a extinção do Ocidente, toleram ser corrigidos? Porque, como veremos, trata-se precisamente de um homem fechado, que não está aberto de verdade a nenhum interesse hierárquico. A divisão da sociedade em massas ou minorias extraordinárias não é, segundo a teoria das massas de Gasset, uma divisão em classes sociais, mas em classes de homens, que pode coincidir com a hierarquização em classes superiores e inferiores. Claro está que nas primeiras, quando chegam a sê-lo verdadeiramente, há mais verossimilhança em achar homens que adotam o "grande veículo", enquanto as últimas estão normalmente constituídas por indivíduos sem qualidade. Mas, a rigor, dentro de cada classe social há massa e minoria autêntica.

Como veremos, é típico do tempo a predominância da massa e do vulgo, mesmo nos grupos em que a tradição é seletiva. Desta forma, na vida intelectiva, que requer qualificação, insinua-se a progressiva vitória dos pseudointelectuais por sua própria tessitura. O mesmo acontece nos grupos sobreviventes da "nobreza". Por sua vez, não é raro encontrar nos dias atuais entre os operários, que antes valiam como o exemplo mais cristalino disto que é conceituado como "massa", almas espantosamente metódicas.

O narrador da ficção de Santos observa que "Nada havia de especial em Manduca. Nem ocorrera, na sua vida, até aquele dia, nada de notável. Caminhando no meio do povo, passaria despercebido." (SANTOS, 1980, p.9). O autor inaugura o seu romance caracterizando o protagonista como parte da massa. Manduca parecia um ratinho pronto a recolher migalhas em plena queda; era aquele que de exclusivamente seu tinha apenas um olhar agudo. E segue pontuando outros personagens de somenos importância, como a cigana Closete, maltrapilha e suja, o enigmático doublé de alfaiate e músico Rosemblim, Marreta, o ferreiro Nero, pretos estivadores, caixeiros viajantes, costureiras, pequenos comerciantes, enfim, todos representantes da classe trabalhadora, moradores da Travessa da Pouca Vergonha. De outro lado, o fatual, estavam agentes da saúde e policiais, representantes do governo que estavam incumbidos de fazer cumprir a lei e a ordem aplicando compulsoriamente a vacina em quantos encontrassem pela frente. 


\section{DE FATO E DE FICÇÃO}

Se a ficção não é uma miragem e sim uma simulação da realidade, quer dizer, se é uma forma de representar o fatual, a conclusão a que chegamos é de que qualquer história que alguém conte será ficcional. Se, como já disse, toda forma de relato é uma tentativa de se reproduzir a realidade através de palavras, logo, ela é uma espécie de ficção. Como exemplifica Gasset (Op. Cit.), É como a famosa pintura do surrealista René Magritte de um cachimbo, seguida dos dizeres "Isto não é um cachimbo"5 . Parece estranho à priori. É óbvio o que vemos é um cachimbo, poderíamos argumentar. Contudo, a frase que acompanha a imagem tem toda a razão. Se você estivesse diante deste quadro, você não poderia pegá-lo e colocar fogo, como poderia fazer se fosse um cachimbo de verdade. A imagem que vemos é uma representação de um cachimbo. Assim como um relato é uma representação de um acontecimento.

A sua cosmovisão, suas vivências pessoais, os livros que leu, os filmes que assistiu, seu estado emocional no instante do acontecido, são algumas das muitas variáveis que influenciarão a forma como você apreenderá a realidade e a registrará em sua mente. Além disso, como observa Gasset (idem, p 57 ):" as pessoas são como icebergs. A parte superficial (externa e visível) é muito pequena se comparada à parte submersa (interna e oculta). Nem nós mesmos conhecemos as profundezas do nosso eu". Se lhe pedirem para descrever um parente muito próximo, você irá resgatar na sua mente a imagem que tem dessa pessoa. Essa representação que você criou para lembrar-se dela, com certeza será um personagem muito rico, com profundidade e absolutamente semelhante à pessoa que ela representa, mas essa representação mental, a complexidade de uma vida humana jamais conseguiria ser completamente transmutada em personagem de uma narrativa. A narrativa literária, tanto quanto as narrativas histórica e jornalística são igualmente inventadas, porque dependem dos recursos da imaginação, que operam a memória, para recordar, reconhecer, relacionar e ordenar narrativamente os eventos apurados ou testemunhados. E por causa disso, toda narrativa, seja ela baseada em eventos reais ou fantasiosos, tem essa característica de ficcionalidade, porque deriva-se da memória. Somente o fato, no presente, no instante em que ele acontece, é que é fatual. Qualquer tentativa de retomá-lo num futuro, será parte da imaginação de alguém, ou seja, será ficção.

Na verdade, a fronteira que costumamos usar entre fato e ficção é ilusória, mas ao mesmo tempo agradável. Ilusória pelas razões que já expliquei; agradável porque nos faz acreditar que é possível existir neutralidade ao relatar um acontecimento, ao se noticiar algo, ao contar uma história, quando, na verdade, não há narrativa fatual, senão o próprio acontecimento. Essa desilusão, de que todas as 
informações que obtemos não passam de versões - e que elas são muito afetadas pela visão de mundo daquele que a registrou - nos faz questionar até mesmo o conceito de "verdade", que como outros conceitos é absolutamente relativo. Mas o mais importante de tudo isso não é que passemos a desacreditar completamente de tudo que lemos, assistimos ou ouvimos. O importante é que levemos esses fatores em conta ao ter contato com alguma história ou informação e saibamos buscar fontes variadas para, a partir de diferentes pontos de vista sobre um mesmo fato, construirmos a nossa própria opinião. E quanto mais nós formos céticos na nossa busca de informações, mais chances teremos de chegar próximo do verdadeiro acontecimento, embora ele seja inalcançável - e mais próximos chegaremos de uma verdade - se é que ela realmente existe.

As palavras acima foram necessárias para que possamos sopesar a tênue linha entre fato e ficção e constatar de que variadas maneiras pode a vida imitar a arte e vice-versa. O narrador de Joel Rufino observa que

O ano de 1904 foi sem dúvida o mais misterioso da História do Brasil.Em São Paulo, por exemplo, as pessoas que esperavam ansiosamente o romper do ano tiveram uma surpresa. Desde as vinte e três horas o céu ganhou uma claridade baça, com estrias vermelhas, como se não fosse noite. Consequentemente, não houve o esperado amanhecer de primeiro de janeiro de 1904. (SANTOS, 1992, p.13).

Com o advento a pandemia no final de 2019, a humanidade em peso também sentiu como se o ano de 2020 tivesse sido eliminado do calendário. O isolamento social, as medidas de prevenção contra o vírus, a reinvenção de novas formas de convívio social, a queda econômica, o desemprego, tudo isso nos fez enxergar que estes últimos vinte meses não passaram de um pesadelo do qual todos queremos acordar.

As mesmas estrias vermelhas que tingiram o céu ficcional de Rufino há quarenta anos e pegaram os paulistanos de surpresa também surpreenderam o planeta com a cor vermelha da morte generalizada, com a dor da perda de familiares e amigos, com a impotência diante da fragilidade humana e da fugacidade da vida. Simbiose de arte e realidade, "No Rio, em São Paulo, em Porto Alegre, por toda parte apareceu um jogo estranho. Um grupo de caras de um lado, outro grupo de caras de outro" (Idem, p.14) e a vacina como intermediária. Na ficção como na vida, sempre os motivos políticos são os reais vetores das rebeliões. 


\section{3. "HOMEM MASSA" VERSUS "HOMEM NOBRE"}

Na narrativa de Joel Rufino dos Santos a hora de dormir chegou na delegacia dos Andradas. A voz de um portuguesinho sai pelas grades:

_A justiça está sempre contra os pobres. Sempre, amigos.Além disso, é uma
ironia esse carcereiro chamar-se Spartaco. Spartaco era um homem grande, mas
por dentro. Sempre haverá homens como estes dois Spartacos: o de verdade, do
tempo dos romanos; e este malfeitor, maltratador de pobres indefesos. (Ibidem,
p. 19) Voltando à teoria dos dois tipos de homem apontados por Gasset, o romance de Santos parece ilustrá-los perfeitamente quando se refere aos dois Spartacos: o de verdade, que seria o homem nobre ressaltado pelo filósofo, e o "maltratador" de pobres indefesos, que equivaleria ao homem massa, sem responsabilidades nem perspectiva de vida. O filósofo espanhol aponta no esquema psicológico do homem-massa atual dois traços: o primeiro seria a livre dilatação de seus desejos vitais, portanto, de sua pessoa, e o segundo a ingratidão irrestrita a tudo quanto tornou a sua existência fácil. Um e outro traço também compõem, segundo Gasset, a conhecida psicologia da criança mimada. Legatário de um passado genial de inspirações e de esforços, o novo codinome tem sido mimado pelo mundo que o circunda, que não lhe limita os desejos, dá-Ihe a impressão de que a ele tudo é permitido e a nada ele está obrigado. O Ser submetido a este regime não tem consciência de suas próprias limitações : chega a crer efetivamente que só ele existe, e costuma não contar com os demais, principalmente a não contar com superiores que, mais fortes do que ele, lhe hajam obrigado a renunciar a um desejo, a minimizar-se ou conter-se.

Frequentemente ouvimos a expressão "massa de manobra" e outros corolários para taxar aqueles que estão envolvidos, enfaixados e dominados pela política; que são manipulados, iludidos, comprados, corrompidos e ardilosamente vendados por "velhos caciques de plumagem capciosa” (GASSET, 2013). Diante de panoramas muito mais produtivos e lucrativos em termos sociais e pessoais, o homem massa opta por manter sua existência vegetal, que lhe é mais lucrativa. Antigamente ensinava-se ao homem médio o saber rudimentar de arcar com as consequências dos seus atos, porque era um mundo mal estruturado, um mundo em que as catástrofes eram frequentes e não havia segurança, abundância ou estabilidade. Mas as novas massas encontram pela frente uma paisagem segura, cheia de possibilidades e alternativas à sua disposição, sem depender do menor esforço. Estas massas paparicadas são suficientemente desinteligentes para acreditar que a nova ordem posta à sua disposição tem sua própria gênese e que é tão perfeita quanto a natural. 
A tese de Gasset é, portanto, a de que as massas beneficiárias não considerem certas ordens da vida como organização, mas como natureza. Assim ele explica o absurdo estado de ânimo que essas massas revelam: não se preocuparem com qualquer coisa além do seu bem-estar e não apoiam as suas causas. Como as facilidades da civilização não lhes parece nenhuma invenção extraordinária que se possam sustentar com esforço e cuidados, acreditam que seu papel se resume a reclamá-las de forma imperativa, como se fossem direitos conatos. O narrador em terceira pessoa de Joel Rufino continua descrevendo a homérica, porém não menos satírica cena em que "um sujeitinho míope, muito tesinho na sobrecasaca escura, trepa à estátua de José Bonifácio" (p.23) e brada:

_A vacina não cura, mata! Está confirmado pelos mais prestigiosos do mundo, o que este sacripanta de fraque recusa ver... _ o princípio da vacina é falso. Mil vezes falso. (SANTOS, 1992, p. 23)

O "sacripanta de fraque" é, evidentemente, o Presidente da República, Rodrigues Alves. Voltando ao fatual, a reportagem do jornal Folha de São Paulo datada de 15 de março de 2020 dá conta de que quando o comboio presidencial deixou o palácio da Alvorada no final do dia 15 de março de 2020, o presidente Jair Bolsonaro lançou as bases do que seria a sua marca durante a pandemia da COVID-19 no Brasil: a inobservância às normas sanitárias básicas e o menosprezo pelo potencial de destruição do vírus. Em 15 de Dezembro Bolsonaro diz que não vai tomar vacina: "eu não vou tomar vacina e ponto final. Minha vida está em risco? O problema é meu".

A questão envolvendo o problema da vacinação se apresenta, entre fato e ficção, como um litígio em que seus defensores e detratores se engalfinham tendo como convicção, à primeira vista, o fato da eficácia ou ineficácia do imunizante.

Enquanto o presidente Rodrigues Alves a defende e o povo a condena em 1904, o presidente Jair Bolsonaro a condena e o povo a defende no século posterior. Na ficção de Rufino a voz de um homenzarrão moreno rola na multidão:

O governo afirma que o povo não quer se vacinar porque é ignorante. Mentira! Quem sabe aqui o que é a vacina? Você, Norimar? E apontou o dedo para um tecelão maneta. _ Você, Alerinda? - e olhou nos olhos de uma vendedora de chapéus. $O$ governo trata o povo com se ele fosse gado: para que explicar alguma coisa ao gado?( Idem, p. 30).

E o orador prossegue apontando seis ou sete outras razões - certamente as mais verossímeis - para a rebelião popular:

O comércio apresentou cinquenta e três falências nos últimos meses. Os moradores foram expulsos pelo Bota-Abaixo. Trezentos e cinquenta demolições! E anuncia-se mais outro tanto! O proprietário tem a indenização, 
custa a receber, mas recebe. E o inquilino? Vai para debaixo das marquises, como vira-latas. Para os morros, como cabritos. (Ibidem, p. 31)

É necessário que voltemos aqui à questão do homem massa. Exemplo melhor não poderíamos encontrar na ficção que o jovem Manduca, protagonista de Quatro Dias de Rebelião. Há alguns meses Gonzalez, emigrante espanhol radicado no Rio, não arranjava emprego. Iria começar a trabalhar como motorneiro da Light naquela madrugada e estava excitadíssimo. A esposa Ângela Ihe havia prometido estar à janela quando o primeiro bonde dirigido por ele passasse na Pouca Vergonha. Ao chegar na garagem do Largo do Machado o rapaz teve uma surpresa: o despachante the disse que os transportes não correriam naquele dia por conta de uma sedição na cidade. Após algum tempo ordens em contrário partiram da diretoria da Light para que os motoristas que estivessem disponíveis pusessem os veículos a funcionar.

Ao chegar no sopé do morro, Gonzalez tem a segunda grande surpresa do dia: Manduca, comandando um assalto, ordena-Ihe que "largue" o bonde: "larga, seu Gonzalez _ senão o pau vai cantar - disse o branco forte" . " _ Escute, Manduca. Eu peguei você no colo..." “_ Ora cale-se, fura-greve! _ corta o filho do açougueiro". (p.41). Como acertadamente observa Gasset, "nos motins que a escassez provoca, costumam as massas populares buscar pão, e o meio que empregam costuma ser destruir as padarias" (2013, p. 75). Do mesmo modo que protestam contra o aumento das passagens nos transportes coletivos incendiando ônibus, por exemplo, aqui os moradores da Pouca Vergonha protestam contra a vacina obrigatória depredando o patrimônio público, ou no mínimo danificando a frota de transporte público que serve à comunidade: “A essa altura, o terceiro assaltante já está trepado no teto do bonde. Desliga-o. Moleques, saídos não se sabe de onde, com ajuda dos marmanjos, começam a virar o veículo" (p.42). Isto pode servir como símbolo do comportamento que, em mais vastas e sutis proporções, usam as massas atuais ante a civilização que as alimenta.

Enquanto antigamente viver significava para o homem comum encontrar ao seu redor dificuldades, perigos, escassez, limitações de destino e dependência, o mundo atual aparece como um âmbito de possibilidades praticamente ilimitadas, sem dúvida, onde não se depende de ninguém. Consoante o filósofo espanhol, em redor desta impressão primária e permanente vai se formar cada alma contemporânea, como em volta da oposta se formaram as antigas. Porque esta impressão fundamental

se converte em voz interior que murmura sem cessar umas como palavras no mais profundo da pessoa e lhe insinua tenazmente uma definição da vida que é, ao mesmo tempo, um imperativo. E se a impressão tradicional dizia: "Viver é sentir-se limitado e, por isso mesmo, ter de contar com o que nos limita", a voz 
novíssima grita: "Viver é não encontrar limitação alguma; portanto, abandonarse tranquilamente a si mesmo. Praticamente nada é impossível, nada é perigoso e, em princípio, ninguém é superior a ninguém". (Idem, p.76)

Esta experiência básica modifica por completo a estrutura tradicional, inextinguível, do "homemmassa" porque o homem comum sentia-se sempre condicionado a limitações materiais e a poderes sociais superiores que eram, no seu modo de ver, a vida. Se ele conseguia progredir e melhorar sua situação, se ascendia socialmente, atribuía o fato a um golpe da sorte, e quando não a isto, a um enorme esforço que ele sabia muito bem quanto havia custado. Em um e outro caso trata-se de uma exceção à índole normal da vida e do mundo; exceção que, como tal, deve-se a alguma causa especial. Mas a nova massa recusa-se a reconhecer seus limites e, por conseguinte, a contar com o apoio de outras instâncias, principalmente com as superiores. Gonzales viu Manduca nascer e o pegou no colo, mas para o jovem isto não é prerrogativa para que lhe deva algum respeito ou consideração. $O$ homem pertencente a ou descendente desta nova ordem está satisfeito tal como é. Inocentemente tenderá a considerar bom tudo o que encontra em si mesmo: conceitos, vontades, preferências ou gostos. Nada nem ninguém o força a compreender que ele é "um homem de segunda classe", limitado, incapaz de criar nem manter a própria organização que dá à sua vida essa satisfação.

Tomemos como exemplo o imbróglio fatual da falta de respiradores em Manaus no início de 2021.Segundo Fernando Rodrigues, diretor de redação do site Poder 360 7 , "O estoque de oxigênio acabou em vários hospitais de Manaus na quinta-feira 14 de janeiro de 2021. Com isso, a situação do Estado do Amazonas no atendimento a pacientes com covid-19 se agravou nas últimas horas", disse. Ainda se manifestando a esse respeito, o pesquisador Jesem Orellana (Fiocruz-AM.) lamentou junto à jornalista Mônica Bergamo, da Folha de S. Paulo, que uma ala inteira de pacientes teria morrido sem ar naquele dia. Profissionais de saúde publicaram vídeos nas redes sociais mostrando a situação crítica dos hospitais. Uma funcionária publicou um vídeo no qual faz um apelo às autoridades, pedindo por oxigênio. "Pessoal, peço a misericórdia de vocês. Nós estamos em uma situação deplorável. Simplesmente acabou o oxigênio de toda uma unidade de saúde. Tem muita gente morrendo. Quem tiver disponibilidade, oxigênio, por favor, traga aqui para o Serviço de Pronto Atendimento, tem muita gente morrendo", disse a profissional aos prantos.

Essa comoção nacional fez com que muitos membros da classe artística se prontificassem a auxiliar os hospitais necessitados, prestando socorro imediato em forma de envio de centenas de cilindros de oxigênio comprados e transportados ao local com recursos do seu próprio bolso, sem esperar pela morosa ajuda governamental. Digamos que, representando classe artística, esteve o humorista 
Whindersson Nunes, o primeiro a mobilizar-se no sentido de ajudar os manauaras e a convocar outros colegas a fazer o mesmo ${ }^{8}$ e, representando os influenciadores digitais, esteve o youtuber Felipe Neto, o primeiro a criticar os doadores por considerá-los "caçadores de likes", muito embora em seguida tivesse aderido à causa e publicamente divulgado o envio de cinquenta unidades de cilindros de oxigênio aos hospitais necessitados.

Nunca um homem-massa como este último teria apelado para nenhuma instância fora dele se a conjuntura não lhe houvesse forçado a isso. Como agora as circunstâncias não mais o obrigam, o eterno homem-massa, de acordo com sua índole, deixa de apelar e sente-se dono da sua própria vida. Na sua contramão, o homem nobre é constituído por uma necessidade pessoal de apelar a uma norma superior a ele, a cujo serviço livremente se põe. Gasset distingue o homem excelente do homem vulgar dizendo que aquele é o que exige muito de si mesmo, que vive em essencial servidão, aquele a quem a vida não apraz se não a faz consistir em serviço de algo metafísico e este, o que não exige nada de si, o narcisista, é o que apenas contenta-se com o que é e está perdidamente encantado consigo mesmo.

Segundo o filósofo, a nobreza define-se pela exigência, pelas obrigações, não pelos direitos. Os privilégios da nobreza não são originariamente concessões ou favores, mas, pelo contrário, são conquistas, e, em princípio, sua conservação supõe que o privilegiado seja capaz de readquiri-las a todo momento, se for necessário e se alguém as disputar. Na ficção de Santos, ao nos transportarmos para a sala de despacho do palácio do Catete no Rio de Janeiro de 1904, então sede do Governo Presidencial, vamos encontrar um enclausurado presidente Rodrigues Alves estarrecido com a bombástica revelação do Coronel Silva Piragibe de que mais de cem rebeldes os haviam atacado de

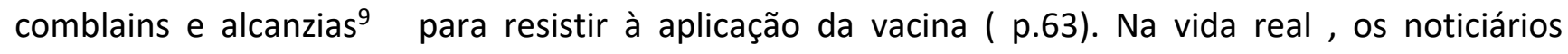
jornalísticos, televisivos e a rádios nos dão conta de que um presidente Jair Bolsonaro andeiro e contrário à vacina procurava aglomerar-se, sem o uso de máscara, para erradicar a covid-19 por disseminação do vírus. Bolsonaro mantém seu discurso contra a vacina e afirma no dia 1ํo de setembro de 2020: "Ninguém pode obrigar ninguém a tomar vacina". O presidente diz que não tomará vacina e que, se a pessoa tomar e "virar jacaré", "o problema é dela". Ao comentar uma cláusula do contrato da Pfizer, afirma de que não se responsabilizará por eventual efeito colateral do imunizante.

Quando o país já somava 186.365 mortes por Covid, o presidente afirmava, em vídeo publicado nas redes sociais, que a pandemia estava acabando e que a pressa da vacina, portanto, não se justificaria. Sendo assim, pela ótica de Gasset - mesmo cem anos após a publicação da sua obra - depreendo que 
o atual presidente do Brasil seria este "homem-massa": carente de projetos, aspirações, premissas, desconhecedor da autoridade da minoria dominante, pelo contrário, querem tomar-lhe o lugar em benefício próprio. Enquanto o homem nobre reconhece suas limitações, mas deseja aperfeiçoar-se, o homem-massa exacerba sua trivialidade, seu direito de ignorar; é negacionista, misantropo, vangloriase de ser como todos, não cumpre a missão a que foi destinado, enfim, não é autêntico, o que lhe agrega, no meu entendimento, na maior parte das vezes uma falha de caráter.

\section{QUESTÕES SUBLIMINARES}

O segundo ponto ventral deste estudo é o que subjaz a questão da vacina, tanto na ficção quanto de fato. Já expus antes a minha opinião de que que a vacinação é o pretexto para que se manifestem outros descontentamentos por parte da sociedade: em Quatro Dias de Rebelião as pessoas se revoltam quanto às atitudes do presidente Rodrigues Alves, típico representante da oligarquia cafeeira, que realizou reformas modernizadoras no Rio de Janeiro. Essas reformas visavam a um embelezamento e modernização da cidade, além de promoverem sua gentrificação ${ }^{10}$, expulsando os pobres das regiões centrais e forçando-os a morar em locais mais afastados do centro.

O narrador do romance de Santos nos pergunta, ao final do terceiro dia de rebelião: _Quem eram os políticos inimigos de Rodrigues Alves que pretendiam se aproveitar da rebelião popular para derrubar o governo?" (SANTOS, 1980, p.86). Em primeiro lugar vinham os florianistas, que não queriam exatamente a volta de Floriano Peixoto ao poder, uma vez que este já havia morrido; queriam uma espécie de revival do espírito de Floriano, honestidade e trabalho para construir uma pátria grande". Em segundo lugar havia os positivistas, partidários de um governo forte, preferentemente militar, que como os primeiros achavam Rodrigues Alves "um banana"(p.87).

No Brasil atual o negacionismo do presidente Bolsonaro quanto às mortes ocorridas pela demora na compra das vacinas também tem como pano de fundo outras questões que remetem à sua postura antidemocrática, que é um problema político. A prova disto é que ele já conta com inúmeros pedidos de impeachment protocolados, pelos mais diversos motivos. Nos dias que se seguiram outras controvérsias surgiram envolvendo esta e outras questões administrativas. Por hilário que possa parecer, ao contrário do que disse antes, o presidente Bolsonaro assinou uma lei que prevê a vacina obrigatória. A declaração de Bolsonaro foi dada depois de uma apoiadora pedir para que o governo "não deixe fazer esse negócio de vacina". A opinião do presidente ainda foi corroborada pela 
Secretaria de Comunicação do Governo Federal (SECOM), em publicações nas redes sociais, e pelo vice-presidente Hamilton Mourão.

A mesma pergunta feita antes podemos fazer agora em relação a Jair Bolsonaro: a que políticos inimigos do presidente interessa se aproveitar das revoltas e panelaços populares para derrubá-lo do governo ? Em primeiro lugar viriam os lulistas e os adeptos do regime comunista, que mesmo tendo plena consciência de que o ex-presidente Luis Inácio Lula da Silva protagonizou o maior roubo aos cofres públicos de toda a história mundial moderna, dariam tudo para tê-lo de volta ao poder; em segundo lugar viriam seus desafetos políticos, pretensos concorrentes à eleição presidencial de 2022 e uma vasta gama da população que na eleição de 2018 apostou todos os seus créditos em um potencial "salvador da pátria", defensor da família, da moral e do bons costumes, figura "incorruptível" que metamorfoseou-se no final das contas em uma figura instável, antidemocrata, irascível e incongruente como tem se mostrado atual presidente do Brasil.

Resta-me agora racionalizar um pouco mais sobre a relação entre fato e fiç̧ão. Vicente Ataíde (1973) chama atenção para o fato de que a literatura tem a função de recriar a realidade por meio da imaginação do artista. $O$ escritor, no caso, possui um conhecimento que tende a expandir-se para que possa ser fruído pelo leitor. Ocorre que pela razão ou inteligência, que atua como subsidiária, existe uma operação de escolha e montagem dos fenômenos, fatos e coisas percebidos na realidade. A inteligência assessora a imaginação. É tanto que, como falei no início deste estudo, Joel Rufino escreve a título de prefácio uma "necessária advertência" ao público leitor de Quatro Dias de Rebelião afirmando que a história "não foi totalmente inventada[...] Alterei também, ligeiramente, alguns fatos históricos[...] De resto, contei o caso como o caso foi" (p.6). Assim, "o objeto da especulação literária é a realidade, tomada em sentido amplo, observando as regiões mais fundas do sujeito e as mais exteriores.[...]através das palavras, o sujeito da comunicação quer dizer o que observou, o que sentiu, o que intuiu" (ATÍDE, 1973, p.4).

Assim é que uma obra literária , na sua gênese, busca grande quantidade de material no meio de onde sai e é por isto que ela resulta em um dado cultural. _ E o que é a cultura senão um conjunto de conhecimentos, atividades, atitudes, hábitos, recursos, técnicas, pensamentos, sentimentos e sensações de um determinado grupo humano dentro do seu ambiente físico, social e psíquico?

Sendo o artista pertencente à sua cultura, assim como o leitor, a sua obra se desenvolve em torno da linguagem, que é um acervo cultural. Deste modo, o comportamento ideológico suscitado pela obra está diretamente ligado pela circunstância relacionando-se com ela estreitamente. Enquanto processo 
genético a obra literária é imitação da realidade e às vezes com ela se funde numa impressionante simbiose entre o que a intenção criadora do escritor assume como correspondência real e a realidade subscreve como contingência da mente mais criativa.

\section{CONCLUSÃO}

Este estudo comparatista enfocou dois pontos fundamentais: a relação entre fato e ficção, seus limites e fronteiras, e a análise comportamental dos personagens da ficção e da realidade tendo como pano de fundo a vacinação contra as doenças epidêmicas e a posição assumida por seus respectivos protagonistas contra ela, à luz da teoria da massificação proposta pelo filósofo espanhol José Ortega y Gasset (2013) .

O primeiro deles carece de alguns esclarecimentos quanto à sua origem: costumou-se abordar as narrativas a partir de uma distinção entre as narrativas fatuais e as ficcionais, conforme sua concretude histórica ou inventividade. Quando falamos em ficção imediatamente imaginamos histórias fantásticas, que envolvem elementos surreais, como bruxas, monstros, duendes, fantasmas, ou tecnologias superavançadas, respectivamente. Além disso, também associamos a ficção às histórias que, mesmo não tendo estes elementos, foram criadas, inventadas, e nunca aconteceram.

As narrativas que lemos nos veículos midiáticos e nos livros de História são fatuais, já que são referentes a acontecimentos que realmente aconteceram e não foram inventados. Resta que a ficção é uma forma de discurso que faz referência a personagens ou a ações que só existem na imaginação daquele que a escreve, ou lê, mas simula a realidade. Ora, se a ficção é um simulacro da realidade, quer dizer, uma representação do real, qualquer história que se ouça ou leia será ficcional. Como propus antes, toda forma de relato é uma tentativa de se reproduzir a realidade através de palavras proferidas ou escritas-, logo, é uma espécie de ficção.

As reportagens que lemos no jornal, as matérias de televisão, as notícias do rádio falam sobre fatos reais, não são inventadas como em um conto ou romance, por exemplo. Sendo assim, a lógica ditaria que elas não podem ser ficções. Mas a versão de um fato que cada narrador tem em mente é um simulacro, ou seja, uma representação da realidade, razão pela qual pessoas diferentes não podem criar versões iguais de um mesmo acontecimento, uma vez que esse simulacro é diretamente influenciado por elementos subjetivos do indivíduo: sua mundivisão e suas experiências pessoais. Estes são alguns dos pontos que irão interferir na forma como o narrador apreenderá a realidade e a registrará em sua mente. Além disso, nem nós mesmos conhecemos as profundezas do nosso eu. 
Assim, a complexidade de uma vida humana nunca conseguirá ser completamente transposta para o personagem de uma narrativa. Tanto a narrativa literária, quanto as narrativas histórica e jornalística são igualmente "inventadas", como demonstra Santos em sua advertência/prefácio em Quatro Dias de Rebelião: "o processo literário em que se atribuem palavras e gestos irreais a pessoas reais é velho e conhecido" (SANTOS, 1980, p.2). Como dito no início deste estudo, narrar essa complexidade irá depender dos recursos da imaginação, que operam a memória, para lembrar, reconhecer, selecionar e ordenar os eventos verificados ou testemunhados. Por este motivo, toda narrativa, seja ela baseada em eventos reais ou fantasiosos, tem essa característica de ficcionalidade, porque deriva da memória. Somente a ocorrência no presente, no momento em que acontece, é que é fatual . Qualquer tentativa de retomá-la no futuro, será parte da imaginação de quem a narrou, ou seja, será ficção.

Na verdade, a fronteira que se apresenta entre fato e ficção é ao mesmo tempo "ilusória e agradável" , como assegura Daisi I. Vogel em “A ficção do relato jornalístico" (2005). Ilusória pelos motivos acima elencados e agradável porque nos faz acreditar que é possível existir neutralidade ao relatar um acontecimento, ao narrar algum fato ou contar uma história. O que se descobre é que não há narrativa fatual, senão a do próprio momento do acontecido. Joel Rufino dos Santos nos esclarece esta dúvida de pronto no seu preâmbulo: “...Alterei também, ligeiramente, alguns fatos históricos. A verdade histórica, porém, foi respeitada.

Assim, na esteira do que defende Vogel, quanto mais formos indisciplinados na nossa busca de informações, mais chances teremos de nos aproximarmos do verdadeiro acontecimento (embora, como sabemos, ele pareça inalcançável) e mais perto chegaremos da "verdade", se é que se pode assim afirmar. Em todo caso, ao aproximarmos a fiç̧ão de Santos dos relatos jornalísticos e televisivos sobre o personagem real e atual da história do Brasil, aquele discurso saído do mesmo momento acontecido, vamos encontrar vários pontos de interseção entre o ficcional e o fatual, se utilizarmos como respaldo os aparatos teóricos da Literatura Comprada.

Ao abordar o segundo ponto, o cotejamento entre o comportamento do protagonista do romance e o do presidente do Brasil deste século sobre a questão da vacinação levando em consideração os conceitos de vida nobre e vida vulgar, ou do esforço e da inércia apontados por Gasset, Concluo, como o autor, que das massas brotam dois tipos de homens distintos: O homem médio, que se contenta em seguir a corrente, que despreza a tradição, é desprovido de senso histórico, não tem grandes aspirações e espera que o Estado resolva todos os seus problemas e está sempre esperneando, gritando por direitos, mas não tem atitude, senso de dever, nem de responsabilidade. Tende à 
violência e acredita que o progresso advém do destino manifesto ao invés de reconhecê-lo como fruto do sacrifício e do trabalho das gerações anteriores. Na ficção e na vida eles são representados por Manduca e o presidente do Brasil, respectivamente.

De outro lado existe o homem nobre de postura, com forma de ser. Tem senso histórico, respeita a tradição, as conquistas de seus antepassados. Possui senso de dever, honra suas responsabilidades. Não espera que o Estado resolva seus problemas, não entrega seu destino nas mãos do Governo. Ele é dono do seu destino e busca o aperfeiçoamento mediante o esforço e o compromisso. Este tipo de homem não pretende resolver os problemas estruturais e sim os pontuais, não quer mudar o mundo, mas melhorá-lo. Valoriza a moral e os valores civilizatórios, a disciplina, a ordem e a lei. Vamos encontrar seus representantes ficcionais no ferreiro Nero, do romance de Santos e nos artistas que resolveram o problema de Manaus, na vida real.

Como diria Diana Margarita Sorgato em sua resenha (2021), o homem-massa ainda predomina em nossa sociedade, o que é perceptível em todos os campos de conhecimento. Na língua, por exemplo, observa-se a desvalorização da norma, a rejeição ao estudo formal, ao mesmo tempo que se exalta a vulgaridade, quando fervem nas vitrines das livrarias os livros de autoajuda com palavrões, inclusive no título. Segundo Sorgato, o que se verifica é o empobrecimento do vocabulário, a subvalorização da leitura, o intento de considerar a gramática, a norma culta da língua e sua língua como ferramentas opressoras. Hoje procura-se buscar conhecimento fácil e fútil por meio da lei do menor esforço, ou seja, dos macetes. O desprezo aos clássicos da literatura nacional e supranacional, a deterioração da hierarquia na relação professor/aluno e o espelho das reivindicações políticas na língua, com a imposição da linguagem não sexista e do discurso do "politicamente correto". Atualmente, são esses, na opinião de Sorgato, com a qual compactuo, alguns sinais da massificação e da dominação da língua e da lógica.

Voltando à teoria de Gasset e aos exemplos fornecidos pela fiç̧ão e pela realidade, concluo que é do homem nobre, que suscita a ordem, a paz e o amor que o mundo caótico em que vivemos precisa; precisamos de segurança, equilíbrio, espírito fraterno e cooperação entre os seres vivos do planeta. A humanidade haverá encontrado o seu rumo "quando" ou "se" conseguimos nos livrar das amarras da massificação e da manipulação da linguagem e do pensamento; quando através do espírito solidário formos capazes de promover o bem mundial; enfim, quando finalmente o AMOR for a próxima pandemia... 


\section{REFERÊNCIAS}

ATAÍDE, Vicente de Paula. A Narrativa de Ficção. 2a ed., São Paulo: McGRAW-HILL do Brasil, 1973.

BAUMAN, Zygmunt. Tempos Líquidos. Trad. Carlos Alberto Medeiros. Rio de Janeiro: Zahhar, 2007.GASSET, José Ortega y. A Revolução das Massas. Trad. Herrera Filho. Lê Livros, 2013. Edição digital disponível em

file://C:/Users/sueli/OneDrive/\%C3\%81rea\%20de\%20Trabalho/A_Rebeliao_Das_Massas_Jose_Orte ga_Y_Gass.pdf.

SANTOS, Joel Rufino dos. Quatro dias de Rebelião. 4a Ed. São Paulo: FTD, 1992

SANTOS, Paulo Sérgio Nolasco dos Literatura e práticas culturais. Formato: eBook Kindle, 2012.

SANTOS, Paulo Sérgio Nolasco dos \& ALVES, Joyce. "Literatura Comparada: Trajetórias e Perspectivas" In: Revista Literatura: teoría, historia, crítica. Vol. 15, n. 1, enero - junio 2013 ·pp. 17-33

SORGATO, Diana Margarita. "Resenha: A Rebelião das Massas" - 2021. Disponível em https://contraosacademicos.com.br/blog/resenha-a-rebeliao-das-massas- Acesso em 13/09/21.

VOGEL, Daisi I. "A Fiç̧ão do Relato Jornalístico" 2005. Disponível em file://C:/Users/sueli/OneDrive/\%C3\%81rea\%20de\%20Trabalho/A\%20fic\%C3\%A7\%C3\%A30\%20do\% 20relato\%20jornal\%C3\%ADstico.pdf. Acesso em 23/09/2021

WEINHARDT, Marilene \& CARDOZO, Maurício Mendonça (Org.) Centro, Centros: Literatura e Literatura Comparada em Discussão. Curitiba: Ed. Da UFPR, 2011 


\section{NOTAS}

\section{Nota 1}

Militar, político e líder republicano que se envolveu na Revolta da Vacina, quando aproveitou para sublevar os cadetes da Escola Militar da Praia Vermelha e teve influência sobre o levante frustrado da Escola Preparatória de Realengo. Foi preso ao final do episódio. O Senador Lauro Sodré se opunha à vacinação obrigatória, alegando a medida como cerceadora das liberdades individuais.

\section{Nota 2}

Rousseff foi a candidata esquerdista escolhida pelo ex-presidente Luis Inácio Lula da Silva para concorrer às eleições presidenciais de 2014, por encontrar-se impossibilitado de concorrer ao cargo pela terceira vez, uma vez que já havia sido reconduzido a ele por um segundo mandato consecutivo.

\section{Nota 3}

Disponível em https://g1.globo.com/politica/cpi-da-covid/noticia/2021/10/26/cpi-da-covid-aprovarelatorio-atribui-nove-crimes-a-bolsonaro-e-pede-80-indiciamentos.ghtml. Acesso em 30/10/21

Nota 4

Gasset define o politicismo integral como característica do homem-massa, aquele que é tão envolvido pela política que fica como que cego, apenas se deixa enfaixar por e pela política, sem ter em horizonte nada além dela. Esquece o homem-massa de que há outras habilidades ou atividades além dessa visão nociva e bloqueadora, totalmente limitada.

\section{Nota 5}

Michel Foucault publicou um ensaio homônimo em 1968, em homenagem a Magritte, falecido no ano anterior, dois anos depois de o filósofo escrever As Palavras e as Coisas (1965), e tem origem numa das cartas que o pintor Ihe endereçou depois da leitura desse livro, ou do capítulo sobre "As Meninas", do pintor espanhol Diego Rodríguez de Silva y Velázquez, em que ele reflete sobre as noções de semelhança e similitude.

\section{Nota 6}

Disponível em:

https://www1.folha.uol.com.br/poder/2021/03/ha-um-ano-participacao-de-bolsonaro-em-atolancou-bases-do-negacionismo.shtml

Acesso em 17 de agosto de 2021

\section{Nota 7}

Disponível em

https://www.poder360.com.br/coronavirus/oxigenio-acaba-em-hospitais-de-manaus-profissionaisde-saude-pedem-ajuda/. Acesso em 08/09/2021 
Nota 8

Por ação voluntária de mobilização para doar respiradores e cilindros de oxigênio a hospitais de Manaus em janeiro deste ano, o humorista piauiense Whindersson Nunes, de 26 anos, foi agraciado com o título de Cidadão do Amazonas.

Disponível em:

https://amazonasatual.com.br/por-acao-voluntaria-deputados-do-am-concedem-titulo-de-cidadaoa-winderson-nunes/ Acesso em 08/09/2021

Nota 9

O Fuzil Comblain era um fuzil belga de tiro único por ação de bloco cadente e de alavanca, que disparava cartuchos metálicos de um cano estriado, projetado em Liège por Hubert-Joseph Comblain e produzido em muitas variantes por várias fábricas belgas. Havia versões para infantaria, cavalaria, com e sem apoio de baioneta. Também foi construído para a caça. Foi usado pelos exércitos da Bélgica, Brasil, Chile, Grécia e Peru. Alcanzia: Espécie de granada que se atirava com a mão.

Nota 10

Gentrificação é um processo de transformação de centros urbanos através da mudança dos grupos sociais ali existentes, onde sai a comunidade de baixa renda e entram moradores das camadas mais ricas. O fenômeno decorre da revitalização urbana, em que espaços até então abandonados passam a ser vistos com potencial por determinados grupos sociais e econômicos. 


\section{Capítulo 5}

\section{doi $10.37423 / 220105195$}

\section{UTILIZAÇÃO DA RESERVA PARA CONTINGÊNCIAS: UMA ANÁLISE DAS EMPRESAS DE CAPITAL ABERTO}

Jefferson Alex Santos e Silva

Ítalo Almeida Andrade

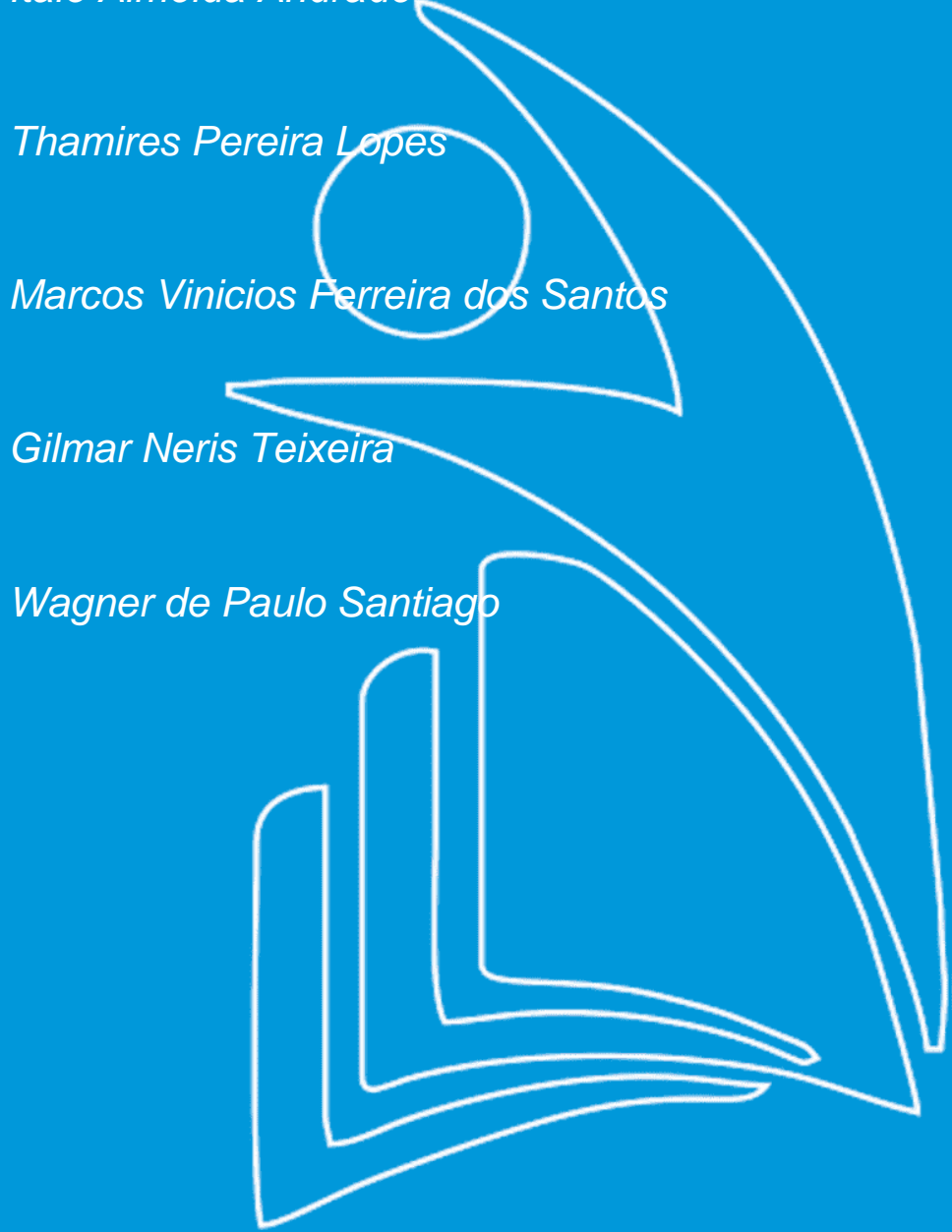

Universidade Estadual de Montes Claros Unimontes

it.santos13@gmail.com

Universidado Estadualde Montes Claros Unimontes

Univgrsidade/Estadul de Montes Claros Unihontes

Uhiversidade Estadual de Wrontes Claros -

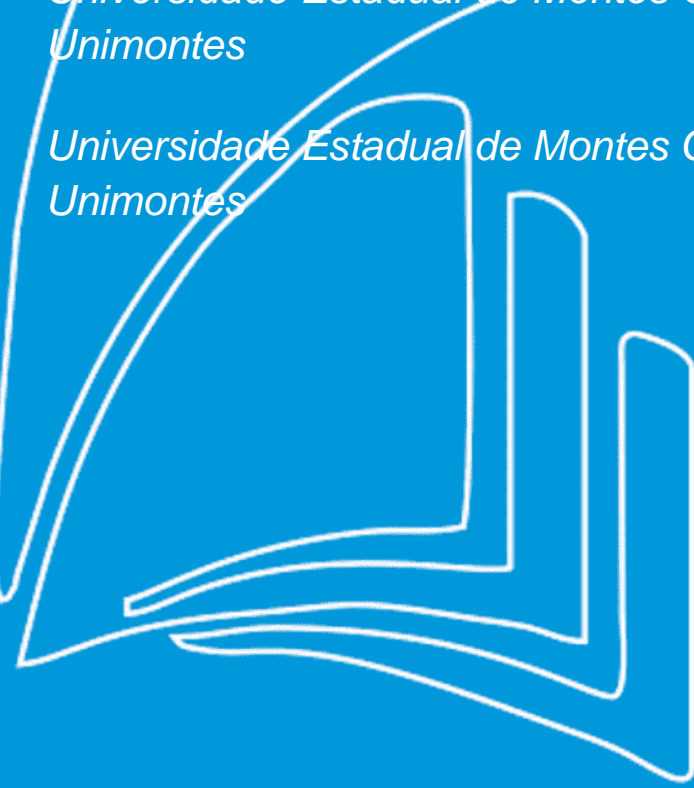


Resumo: Este artigo buscou analisar empresas do Brasil quanto ao reconhecimento das Reservas para Contingências, bem como verificar as empresas que optaram pela sua utilização, analisando os motivos que ocasionaram a instituição dessa reserva e como ocorreu o processo de reversão. Para o desenvolvimento da pesquisa foram analisadas 1.548 (mil quinhentos e quarenta e oito) organizações listadas na B3, utilizando os dados da Economática ${ }^{\circledR}$ e o estudo das demonstrações contábeis, notas explicativas, relatórios da administração e de auditores das 15 (quinze) companhias que apresentaram movimentação da conta Reservas para Contingências entre os anos de 1996 e 2019, averiguando o cumprimento das exigências legais relacionadas. Os resultados demonstram que as empresas analisadas não cumpriram adequadamente o disposto no artigo 195 da lei 6.404/76, revelando lacunas nos processos contábeis que envolvem as Reservas para Contingências, verificando-se uma necessidade de melhoria na evidenciação contábil.

Palavras-chave: Reserva para contingências, Evidenciação contábil, Reservas de lucros. 


\section{INTRODUÇÃO}

Na segunda metade da década passada, mais precisamente em 2007, a contabilidade brasileira, até esse momento regida principalmente pela Lei 6.404/76 - Lei das Sociedades Anônimas (BRASIL, 1976), iniciou o processo de convergência com as normas internacionais de contabilidade por meio da Lei 11.638/07 (BRASIL, 2007), que alterou alguns aspectos contábeis da Lei das Sociedades Anônimas. Nesse sentido, e com a ampliação das multinacionais pelos mais variados mercados no mundo, as demonstrações contábeis são instrumentos que representam em sua divulgação, confiabilidade e transparência.

Dentre as demonstrações, o Balanço Patrimonial "é a demonstração financeira (contábil) destinada a evidenciar, quantitativa e qualitativamente, numa determinada data, a posição patrimonial e financeira da empresa" (RIBEIRO, 2013, p. 412). Na visão de Pereira, Silva e Carvalho (2014), essa demonstração é capaz de mostrar informações sobre dados relacionados ao passado, presente e futuro das organizações.

As Reservas para Contingências, resumem-se no valor oriundo do lucro, destinado para compensar prováveis perdas para os exercícios seguintes. No entanto, a constituição dessa reserva se restringe às situações existentes nas datas das demonstrações mediante informações contábeis previstas. Sendo assim, é importante salientar e compreender o seu caráter preventivo, demonstrado pela reversão da reserva ao lucro caso os motivos geradores da constituição dessa reserva não se concretizem, pois nessa situação não haverá mais justificativas para sua existência no Patrimônio Líquido. Essa reserva se apresenta como instrumento legal e disciplinada na Lei 6.404/76:

Art. 195. A assembleia-geral poderá, por proposta dos órgãos da administração, destinar parte do lucro líquido à formação de reserva com a finalidade de compensar, em exercício futuro, a diminuição do lucro decorrente de perda julgada provável, cujo valor possa ser estimado.

§ 1 을 proposta dos órgãos da administração deverá indicar a causa da perda prevista e justificar, com as razões de prudência que a recomendem, a constituição da reserva.

$\S 20$ A reserva será revertida no exercício em que deixarem de existir as razões que justificaram a sua constituição ou em que ocorrer a perda. (BRASIL, 1976)

Diante do exposto, questiona-se: Quais empresas constituem a Reserva para Contingência, por quais motivos e como se deu a reversão?

De forma a responder ao problema de pesquisa tem-se como Objetivo Geral: 
Verificar quais empresas constituem a Reserva para Contingência, bem como citar os motivos que levaram as empresas a adotarem a constituição desta reserva e como se deu a reversão.

Como objetivos específicos se tem:

Verificar quais empresas adotaram a Reserva para Contingência no período compreendido entre os anos de 1996 a 2019.

Evidenciar os motivos que levaram as empresas a adotarem a Reserva para Contingência e se a constituição se deu em consonância com o previsto em lei.

Analisar se houve a reversão da Reserva para Contingência e se houve consonância ao texto Legal.

Analisando a literatura relacionada ao tema, identificou-se que autores buscaram verificar e esclarecer a constituição das Reservas para Contingências e suas utilizações. Este é o caso de Albuquerque e Faria (2009), da Universidade do Vale do Paraíba, que pesquisaram empresas que publicaram suas demonstrações contábeis e negociaram suas ações na BM\&F Bovespa (atual B3), no exercício de 2008 e obtiveram como resultado indicadores de utilização discretos. Não obstante, Araújo (2013), da Universidade Federal do Rio Grande do Sul - UFRGS, discorreu acerca da destinação dos resultados, revelando uma ínfima aplicação nessa reserva em comparação com as demais, tendo como referência as Companhias Abertas Brasileiras, possuidoras de ações negociadas na Bovespa, sendo a amostra composta por empresas que compõem o Índice de Governança Coorporativa Novo Mercado - IGC NM.

Percebe-se que se trata de um assunto ainda pouco explorado, e por vezes não valorizado pelas empresas. Sendo assim, procura-se demonstrar um panorama recente sobre a temática proposta e contribuir para um consequente desenvolvimento, fomento e maior disseminação do assunto na literatura, haja vista que as utilizações incorretas ou inexistentes desse instrumento podem desencadear prejuízos derivados dos riscos previamente não contabilizados, alterações no patrimônio líquido da empresa e ainda análises distorcidas das demonstrações contábeis. Vale ressaltar que as empresas precisaram se adaptar a um ambiente globalizado de riscos e incertezas futuras, sendo que para demonstrar a realidade da empresa e atender as demandas societárias é necessário gerenciar tais fatores, visando garantir a continuidade do negócio. 


\section{REFERENCIAL TEÓRICO}

O referencial teórico está dividido em cinco seções, de forma a elucidar conceitos importantes relacionados à Reserva para Contingências, bem como a legislação aplicada a este assunto. Inicialmente traz o conceito do Balanço Patrimonial, depois traz uma base teórica sobre a Reserva para Contingência e apresenta a distinção entre Reserva para Contingência e Provisão para Contingências e, por fim, como se efetiva a reversão da Reserva e sua relação com a equalização da distribuição dos dividendos.

\subsection{DEMONSTRAÇÕES CONTÁBEIS: BALANÇO PATRIMONIAL}

As demonstrações financeiras e contábeis representam a situação econômica, financeira e patrimonial da entidade, com o intuito de expor, de forma concisa e organizada, o desempenho apresentado pela organização em determinado período. Além de transparecer os fluxos de caixa, atuam de forma a apresentar as variações ocorridas no perpassar do exercício e assim intermediam, por meio de seus dados, o processo decisório de usuários internos e externos, haja vista as diversas finalidades e necessidades. (IUDICIBUS, 2017)

Dentre essas demonstrações, tem-se o Balanço Patrimonial, um relatório contábil gerado após o registro de todas as movimentações econômico-financeiras de uma empresa em determinado período. Esse demonstrativo é dividido basicamente em três grupos: Ativo, Passivo e Patrimônio Líquido. No Ativo encontram-se os recursos controlados pela empresa nos quais se esperam a geração de benefícios futuros, já no Passivo figuram-se todas as obrigações presentes da empresa, nas quais suas liquidações resultem na saída de recursos. E por fim, o Patrimônio Líquido, valor líquido da empresa, ou seja, a parte pertencente aos sócios e acionistas, onde estão registrados o capital social, os lucros (antes da distribuição) ou prejuízos acumulados pela empresa, ajustes de avaliação patrimonial, ações em tesouraria, além das contas de reservas de capital e de lucro que podem vir a ser constituídas, entre elas a Reserva para Contingências. (GELBCKE et al., 2018)

\subsection{RESERVA PARA CONTINGÊNCIA}

A Reserva para Contingência, segundo Imperatore (2017), refere-se à dotação de uma parcela do lucro líquido da organização, sendo classificada como uma espécie de reserva de lucro e localizada dentro do Patrimônio Líquido no Balanço Patrimonial da entidade. De acordo com a Lei 6.404/76 art. 195, ela 
é instituída para os fins recomendados pelo conselho administrativo, e corroborada mediante a aprovação dos membros em assembleia geral. Ribeiro (2013, p. 370), ressalta que:

[...] para que a Assembleia Geral possa aprovar a constituição dessa reserva, o mesmo dispositivo acima estabelece a necessidade de que a proposta dos órgãos da administração indique a causa da perda prevista e justifique, com as razões de prudência, que a recomendem.

A constituição dessa reserva para Müller (2007), tem como propósito evadir à distribuição de parte dos lucros, na qual esse desembolso será preservado no intuito de preparar a organização para situações futuras que possam representar perdas à sociedade. Essas situações de perdas podem implicar em uma redução do lucro ou possibilidade de prejuízo, vislumbrando evitar uma assimetria financeira proveniente da distribuição normalmente realizada dos dividendos do exercício, visto que tais implicações estão relacionadas a fatos extraordinários julgados prováveis e que possam ser fidedignamente mensurados os seus desembolsos. (BLATT, 2001)

Neves e Viceconti (2002) discorrem sobre algumas situações em que o os órgãos da administração preconizam a utilização da Reserva para Contingência, dentre elas, as perdas futuras decorrentes da perspectiva de redução nos preços dos produtos da empresa, ocasionando prejuízos, e mediante previsão de lançamentos de produtos antagonistas com qualidade superior, porém a preços menores.

Os eventos provenientes de fenômenos naturais que estão relacionados diretamente com as operações e a rentabilidade da empresa, também constituem relevância para a existência desse instrumento, sendo eles:

Geadas ou secas, que podem atingir empresas com plantações, criações ou estoques nessas áreas, ou ainda as que dependem desses produtos para suas operações, como no caso de empresas comerciais ou industriais que utilizem tais produtos como matérias- primas em seu processo produtivo ...; cheias, inundações e outros fenômenos naturais que podem ocorrer ciclicamente ... (GELBCKE et al., 2018, p. 1068).

Ademais, as ocorrências de paralisação temporária da produção também podem ser compreendidas como parâmetro para constituição da reserva, e como consequências, perdas devido à paralisação não recorrente, derivada da substituição ou restauração de equipamentos causadas por danos, greves, escassez de suprimentos de matérias-primas por períodos longos. (BLATT, 2001)

\subsection{PROVISÃO PARA CONTINGÊNCIA X RESERVA PARA CONTINGÊNCIA}

A Contabilidade requer dos profissionais uma atualização constante das bases regentes, bem como das ramificações dos assuntos circundantes, para que seja exercida com êxito e conforme intitulação 
dada aos profissionais da área Contábil "produzir e/ou gerenciar informações úteis aos usuários da Contabilidade, para a tomada de decisões" (IUDÍCIBUS E MARION, 1999,

p. 41). Aliando-se a isso, Borba, Poeta e Vicente (2011, p. 2-3) ressaltam:

[...] torna-se necessário que os profissionais tenham uma boa base teórica para que possam resolver problemas inéditos e complexos, que não estejam previstos em normas, o que de certo modo eleva também a responsabilidade e o reconhecimento da profissão perante a sociedade.

Faz-se, então, necessário o entendimento sólido de conteúdos legais, bem como bases e teorias para situações da contabilidade que dizem respeito à atividade diária do contador, inibindo possíveis erros que trarão reflexos, resultando em informações fraudulentas e inconsistentes.

Conforme expõe Ângelo (2005), a contabilidade vem sofrendo uma exigência de dados voltados para o futuro da entidade, onde serão possíveis avaliações por parte de investidores acerca da seguridade e do retorno dos investimentos que foram realizados. Referindo-se:

[...] se a contabilidade tem como uma de suas principais funções suprir de informações úteis os gestores, cabe a ela gerar informações que deem o devido suporte ao processo de tomada de decisões em todos os seus estágios: no reconhecimento do problema, na identificação das alternativas possíveis e na escolha da melhor delas. (BEUREN, 1998, p. 30)

Mediante a isso, tem se explicação para que as informações, ora apresentadas pela contabilidade, espelhem, com clareza e objetividade, a real situação exercida pela empresa, considerando fatos ocorrentes ou de possível ocorrência no futuro, objetivando uma segurança ao investidor em avaliar a situação econômica e financeira da organização que lhe possibilite algum interesse. (ANGELO, 2005)

Condizente com o exposto, a distinção da Provisão e Reserva para Contingência torna-se essencial, visto que são dois objetos que refletem fatos futuros, onde dependerá da sua realização, ocorrência e mensuração para figurar modificações nos Demonstrativos elaborados pela Contabilidade, trazendo informações sobre o atual cenário onde se situa a empresa, considerando fatos que possam vir alterar os resultados da mesma futuramente.

Segundo a Norma Brasileira de Contabilidade - NBC TG 25 (R1) do Conselho Federal de Contabilidade - CFC (CFC, 2009, item 7) a "provisão é um passivo de prazo e valor incerto". Alinhado com o Comitê de Pronunciamentos Contábeis - CPC 25, Gelbcke et al. (2018, p. 1113) cita como requisitos cumulativos para a constituição da Provisão, onde redige que "a entidade deverá ter uma obrigação legal ou não formalizada presente como consequência de um evento passado; será provável a saída de recursos para liquidar uma obrigação; e poderá ser feita uma estimativa confiável do montante da 
obrigação." Em consonância, a Provisão para Contingência é advinda de fato gerador já incorrido e não pago (e em respeito ao Regime de Competência, é contabilmente registrado), possui reflexo nos resultados da empresa, e independe de formação de lucro para ser constituída. Tem por objetivo cobrir o valor de perdas ou despesas que ainda não foram desembolsadas. São exemplos de Provisão para Contingências os "devedores duvidosos, indenizações contratuais, contingências fiscais ou trabalhistas etc." (NOTA EXPLICATIVA DA INSTRUÇÃO CVM №. 59/1986)

A Reserva para Contingência se difere da provisão, pois a provisão trata se de um evento já ocorrido, e a reserva é um evento que tem possibilidade de ainda ocorrer. Ademais, a Nota Explicativa da Instrução CVM №. 59/1986 traz conceitos referentes ao Patrimônio Líquido das Entidades, onde busca esclarecer alguns pontos mediante mudanças que vinham ocorrendo. A Reserva para Contingências tem sua constituição fundamentada em:

- Dar cobertura a perdas ou prejuízos potenciais (extraordinários, não repetitivos) ainda não incorridos, mediante segregação de parcela de lucros que seria distribuída como dividendo;

- Representa uma destinação do lucro líquido do exercício, contrapartida da conta de lucros acumulados, por isso sua constituição não afeta o resultado do exercício;

- Ocorrendo ou não o evento esperado, a parcela constituída será, em exercício futuro, revertida para lucros acumulados, integrando a base de cálculo para efeito de pagamento do dividendo e a perda, de fato ocorrendo, é registrada no resultado do exercício;

- É uma conta integrante do patrimônio líquido, no grupamento de reserva de lucros.

Referente a Provisão para Contingências, ainda conforme Nota Explicativa da Instrução CVM no 59/1986, onde situa a fundamentação da sua constituição:

- Tem por finalidade dar cobertura a perdas ou despesas, cujo fato gerador já ocorreu, mas não tendo havido, ainda, o correspondente desembolso ou perda. Em atenção ao regime de competência, entretanto, há necessidade de se efetuar o registro contábil;

- Representa uma apropriação ao resultado do exercício, contrapartida de perdas extraordinárias, despesas ou custos e sua constituição normalmente influencia o resultado do exercício ou os custos de produção;

- Deve ser constituída independentemente de a companhia apresentar, afinal, lucro ou prejuízo no exercício;

- Visto que o evento que serviu de base à sua constituição já ocorreu, não há, em princípio, reversão dos valores registrados nessa provisão. A pequena sobra ou insuficiência é decorrente do cálculo estimativo feito à época da constituição;

- Não está sujeita à atualização monetária patrimonial (art. 185, LEI № 6.404/76) e sim à decorrente da natureza do evento que a originou;

- Finalmente, se a probabilidade for difícil de calcular ou se o valor não for mensurável, há necessidade de uma nota explicativa esclarecendo o fato e mencionando tais impossibilidades. 
Conforme exposto, a constituição da Provisão e/ou da Reserva para Contingências é citada e especificada, trazendo características pertinentes a cada uma.

\subsection{REVERSÃO DAS RESERVAS}

Na perspectiva de Neves e Viceconti (2002, p.190), a reversão das reservas "deve ser contabilizada quando as causas que justificaram a sua constituição não mais existirem, ou no exercício em que ocorrer a perda". Tal observação corresponde ao texto legislado no art. 195 §2으 da Lei 6.404/76, disciplinando que "a reserva será revertida no exercício em que deixarem de existir as razões que justificaram a sua constituição ou em que ocorrer a perda" (BRASIL, 1976). Dessa maneira, caso os fatos geradores não se realizem, ou seja, os prejuízos não ocorram efetivamente, Gelbcke et al. (2018) relata que a organização deve adotar o procedimento de reversão da reserva ao lucro, debitando a conta de reservas e creditando na conta Lucros Acumulados e posteriormente distribuindo aos acionistas como dividendos. Nessa situação, sem a concretização do evento previsto, as Reservas para Contingência não apresentarão razões para sua permanência no Patrimônio Líquido da empresa, e assim o montante da reserva deverá ser revertido para que a ele possam ser dadas as destinações iniciais, e inclusive, possibilite a equalização da distribuição de dividendos. (RIBEIRO, 2013)

\subsection{DIVIDENDOS}

Os dividendos representam o meio pelo qual o percentual dos lucros advindos do desempenho da organização é direcionado aos acionistas no decorrer dos exercícios. Assim, o sistema de distribuição dos resultados da entidade refere-se à decisão tomada no que diz respeito à parcela de dividendos que serão endereçados aos acionistas e de lucros que serão retidos na empresa (RIBEIRO, 2010). Vale ressaltar que, para Gelbcke et al. (2018), no que tange os termos de disciplina legal, existem alguns pontos relevantes a serem observados no que concerne aos dividendos, presentes na redação do art. 202 da Lei 6.404/76:

Art. 202. Os acionistas têm direito de receber como dividendo obrigatório, em cada exercício, a parcela dos lucros estabelecida no estatuto ou, se este for omisso, a importância determinada de acordo com as seguintes normas:

I - Metade do lucro líquido do exercício diminuído ou acrescido dos seguintes valores:
a) importância destinada à constituição da reserva legal (art. 193); e
b) importância destinada à formação da reserva para contingências (art.
195) e reversão da mesma reserva formada em exercícios anteriores; 
II - O pagamento do dividendo determinado nos termos do inciso I poderá ser limitado ao montante do lucro líquido do exercício que tiver sido realizado, desde que a diferença seja registrada como reserva de lucros a realizar (art. 197);

III - Os lucros registrados na reserva de lucros a realizar, quando realizados e se não tiverem sido absorvidos por prejuízos em exercícios subsequentes, deverão ser acrescidos ao primeiro dividendo declarado após a realização. (BRASIL, 1976)

Analisando do ponto de vista da importância destinada à formação da Reserva para Contingências, em que os dividendos não são distribuídos de forma comum, quando atrelada aos dividendos essa prática procura a equalização da distribuição desse instrumento intertemporalmente, em específico quando se preveem significativas baixas ou eventuais prejuízos no lucro líquido, oriundos de fatos extraordinários (GELBCKE et al., 2018). Nessa vertente, de acordo com Ribeiro (2013, p. 370), "no exercício em que o lucro líquido for satisfatório, parte dele fica retido no Patrimônio para ser, proporcionalmente, distribuído aos acionistas, nos períodos de lucros baixos ou de ausência de lucros".

\section{METODOLOGIA}

A metodologia utilizada baseou-se em estruturas que se distinguem em fins, em que se explicita a finalidade mediante uma pesquisa descritiva e explicativa, e em meios, que definem os instrumentos de coleta de dados, representados mediante pesquisa documental e bibliográfica de forma a evidenciar os objetivos do presente trabalho. Para Gil (2002, p. 17), a pesquisa pode ser compreendida como um "procedimento racional e sistemático que tem como objetivo proporcionar respostas aos problemas que são propostos".

A pesquisa tem caráter descritivo, haja vista que para Vergara $(2016$, p. 74) uma pesquisa descritiva "expõe características de determinada população ou de determinado fenômeno. Pode também estabelecer correlações entre variáveis e definir sua natureza". Essa atribuição deriva-se da exposição acerca das características das Reservas para Contingências, visando demonstrar o nível de ocorrências desse fenômeno nas organizações, além de descrever o tratamento das empresas para com essa reserva.

Trata-se, também, de uma pesquisa explicativa, na qual tem como objetivo tornar algo compreensível, mediante a exposição de justificativas, e para isso esclarece os fatores atuantes no contexto da ocorrência do fenômeno (VERGARA, 2016). Nesse sentido, foram analisados os motivos para 
constituição das Reservas para Contingência, de modo a entender e relacionar os princípios basilares que levaram à instituição.

No que concerne aos procedimentos técnicos, ou seja, quanto aos meios, a pesquisa se classifica como documental, visto que se utilizou dos dados obtidos mediante a observação do Banco de Dados da Economática ${ }^{\circledR}$, licenciado para a Universidade Federal de Minas Gerais (UFMG). Complementando, uma pesquisa documental também pode ser analisada em duas partes:

Há, de um lado, os documentos "de primeira mão", que não receberam nenhum tratamento analítico. Nesta categoria estão os documentos conservados em arquivos de órgãos públicos e instituições privadas, tais como associações científicas, igrejas, sindicatos, partidos políticos etc. Incluem-se aqui inúmeros outros documentos como cartas pessoais, diários, fotografias, gravações, memorandos, regulamentos, ofícios, boletins etc. [...] De outro lado, há os documentos de segunda mão, que de alguma forma já foram analisados, tais como: relatórios de pesquisa, relatórios de empresas, tabelas estatísticas etc. (GIL, 2002, p. 46).

Além disso, é possível classificá-la como bibliográfica, tendo em vista que se utilizou de instrumentos literários disponibilizados ao público em geral, como livros, dissertações, artigos, etc. Na visão de Mattar, Oliveira e Motta (2014, p. 49), "uma das formas mais rápidas e econômicas de amadurecer ou aprofundar um problema de pesquisa é pelo conhecimento dos trabalhos já feitos por outros."

Para isso, foram observados os dados das empresas pertencentes à B3, observando os níveis de adesão e os fatos geradores idealizados mais previstos e passíveis de constituição da reserva por parte das empresas analisadas, e ainda os contextos operacionais e gerenciais em que foram utilizadas ou revertidas. Desse modo, a abordagem desse assunto se delimitou na análise de 12 anos antes da Lei 11.638/07 e 12 anos após. A escolha deste período baseia-se em verificar se após entrar em vigor, a Lei promoveu alguma mudança na constituição ou reversão da Reserva para Contingência.

Nesse sentido, foram coletados dados da Economática ${ }^{\circledR}$ de 1.548 (mil quinhentos e quarenta e oito) empresas. No entanto, observou-se que 15 (quinze) empresas constituíram Reservas para Contingências. Na fase da análise dos dados verificou-se que 2 (duas) empresas não registraram valores na conta patrimonial "Reserva para Contingências" e que 3 (três) empresas não constituíram a reserva estudada, classificando nos demonstrativos como outros tipos de reservas. Sendo assim, para fins dessa pesquisa, foram analisadas 10 (dez) empresas que convergiram ao perfil básico delimitado: Polar, Oderich, Sondotécnica, Newtel Participações, CBCC Contact Center, Cia. Antarctica Paulista, Duratex, CRT Celular, Cor Ribeiro e Vivo. 


\section{APRESENTAÇÃO E ANÁLISE DOS DADOS}

Nesta seção serão apresentados os dados, bem como a análise apoiando-se na teoria descrita na seção 2 (dois) de forma a atingir o objetivo geral que é o de verificar quais empresas constituem a Reserva para Contingência, bem como citar os motivos que levaram as empresas a adotarem a constituição desta reserva e como se deu a reversão. Para tanto, inicialmente foram coletadas informações na base de dados Economática ${ }^{\circledR}$ para posterior confronto diretamente nos sítios da B3, Comissão de Valores Mobiliários - CVM e das empresas selecionadas.

Analisando as Demonstrações Contábeis das empresas por meio da Economática ${ }^{\circledR}$, foram selecionadas 15 (quinze) empresas que constituíram a Reserva para Contingências no período de 1996 a 2019. No entanto, conforme informado na metodologia, 5 (cinco) empresas foram excluídas. Assim, foram analisadas 10 (dez) empresas.

Será apresentado o ano da constituição da reserva, motivo(s) para a constituição da reserva e se houve a reversão da reserva para, em seguida, analisar se as informações seguiram os preceitos legais.

\section{POLAR - IND BEBS ANTARCTICA POLAR SA}

Ano da constituição da reserva:

A Empresa registra valores na conta de Reserva para Contingências no ano de 1999 e teve o seu registro da CVM cancelado em 31 de maio de 2001.

Porém, o valor evidenciado na Economática ${ }^{\circledR}$ e no Balanço Patrimonial é de $\mathrm{R} \$ 1.043 .000,00$ (um milhão e quarenta e três mil reais) enquanto a Demonstração das Mutações do Patrimônio Líquido DMPL não evidencia esse valor e nas Notas Explicativas o valor descrito é de $\mathrm{R} \$ 2.000,00$ (dois mil reais).

Motivo da constituição da reserva:

As Notas Explicativas justificam o motivo da constituição como finalidade de compensar, até o exercício de 2002, a diminuição do resultado decorrente da amortização do valor da maxidesvalorização cambial diferida, ocorrida no trimestre findo em 31 de março de 1999.

\section{REVERSÃO DA RESERVA:}

A reversão ocorreu mediante amortização efetuada em cada exercício social, de maneira a assegurar a manutenção da base de cálculo dos dividendos aos acionistas. 


\section{ANÁLISE:}

Conforme o Art. 195 da Lei 6.404/76, a Polar cumpriu os requisitos legais dispostos, indicando a causa da possível perda e justificando sua constituição, bem como efetuando uma estimativa do valor. A reversão também está conforme legislação, na medida que houve o repasse da conta de Reserva para Contingência para a conta de Lucros Acumulados, assegurando a equalização da distribuição dos dividendos nos anos seguintes. Contudo, há divergência dos valores citados nas Notas Explicativas em comparação com as Demonstrações Contábeis da empresa (Balanço Patrimonial e DMPL), fragilizando e deslegitimando a confiança que esses demonstrativos trazem aos investidores e que, consequentemente, inviabiliza uma avaliação fidedigna da situação econômica e financeira da entidade.

\section{ODERICH - CONSERVAS ODERICH SA}

Ano da constituição da reserva:

Registra valores recorrentes no período de 1997 a 2002 e nos anos de 2006, 2008 e 2009, sendo valores inalterados de $\mathrm{R} \$ 33.000,00$ (Trinta e três mil reais) em todos estes anos. No entanto, não foram encontrados registros desta reserva na DMPL, bem como no Patrimônio Líquido da entidade. Além disso, há inconsistência nos dados informados e obtidos na Economática ${ }^{\circledR}$ com os dados da CVM, não sendo possível informar com precisão o que de fato ocorreu com a reserva. Motivo da constituição da reserva:

Os motivos para constituição da Reserva não são esclarecidos nas Notas Explicativas da Empresa ou em outro relatório/demonstrativo.

\section{REVERSÃO DA RESERVA:}

Não houve reversão do saldo da reserva mediante preceitos legais. Os valores que constavam nos demonstrativos passam a não existir sem nenhuma justificativa nas Notas Explicativas a partir do ano de 2003 e retornam no ano de 2006, novamente, sem nenhum motivo para a constituição.

\section{ANÁLISE:}

A empresa Oderich não atende aos preceitos legais para constituição da reserva. Não há justificativa dos motivos que fundamentam a criação da reserva, estando ausentes os valores que deveriam ser 
estimados (de forma fidedigna) dos prováveis fatos contingenciais. Alguns anos referenciados nas Notas Explicativa apenas citam a Lei 6.404/76, que traz o artigo 195 onde permite a criação da reserva. Não é possível afirmar categoricamente os fatos que justificaram a constituição da reserva, se eles ainda procedem ou não, ou se houve a concretização da perda provável.

Tendo em vista o fato de a empresa constituir a reserva por um longo período e por ser o mesmo valor verifica-se que contraria o disposto na Nota Explicativa da Instrução CVM no 59/1986 que reza que a constituição da Reserva para Contingências deve ocorrer em caso de prejuízos potenciais como extraordinários e não repetitivos. (Grifo nosso)

Ressalta-se, ainda, sobre a necessidade do conhecimento e do entendimento sólido das legislações vigentes por parte do contador, pois erros e/ou informações improcedentes, além do descumprimento de normas, inibem avaliações concretas de investidores e de outros usuários da informação contábil.

\section{SONDOTECNICA - SONDOTECNICA ENGENHARIA DE SOLOS S/A.}

Ano da constituição da reserva:

A empresa registra valores na conta de Reserva para Contingências entre os anos de 2003 a 2018.

Motivo da constituição da reserva:

A empresa justifica sua constituição com dois fatores: uma cobrança que se encontra em via judicial contra a Eletronorte por quebra de cláusula de contrato avalizado pela Eletrobrás e outra justificativa se dá como reforço de Capital de Giro, com o objetivo de suportar os atuais níveis de inadimplência.

No ano de 2005 não foram encontrados indícios da modificação da conta de Reserva para Contingências na DMPL e, conforme análise comparativa do ano anterior, houve aumento na conta figurada no Balanço Patrimonial. Entre 2014 e 2016 verificou-se que houveram novas constituições na Reserva para Contingências sob justificativa descrita acima (manutenção do Capital de Giro da entidade). Nos anos de 2017 e 2018 ocorreram novas constituições, porém não foram encontradas Notas Explicativas fundamentando o motivo da constituição destes novos valores.

\section{REVERSÃO DA RESERVA:}

Houve reversão da reserva em vários anos. No entanto, imediatamente são constituídas novas Reservas para Contingências. Os motivos para reversão são diversos, indo desde a manutenção do 
capital de giro até aplicação em coligadas e controladas, investimentos na migração tecnológica da área operacional, futura aquisição de imóvel etc.

\section{ANÁLISE:}

A Sondotecnica apresenta em suas notas explicativas as causas das possíveis perdas, justificando as constituições, bem como efetuando uma estimativa do valor das operações. No entanto, entende-se que, no que se refere ao motivo informado para constituição da reserva - manutenção do capital de giro - não se enquadra no que a legislação propõe. Acredita-se que deveria ser constituída outra reserva, mas não a de contingência. Além disso, a empresa possui inconformidades na divulgação destas informações, prejudicando a análise e não refletindo de forma adequada o saldo disposto na Reserva para Contingências. Nos dois últimos anos pesquisados a entidade registrou saldos na conta da Reserva para Contingências, mas não justificou a sua criação, prejudicando a evidenciação.

Verifica-se que a nota explicativa não cumpre o seu papel de explicar e melhorar a evidenciação contábil.

\section{NEWTEL PARTICIPAÇÕES - NEWTEL PARTICIPAÇÕES S.A.}

Ano da constituição:

A empresa estaria apresentando em suas demonstrações contábeis, a constituição de Reserva para Contingências no quarto trimestre de 2013 e no primeiro trimestre de 2014, no valor de $R \$ 1.093,00$ (mil e noventa e três reais).

No entanto, ao ser efetuada a verificação das demonstrações contábeis desse período no banco de dados da Comissão de Valores Mobiliários (CVM), foi constatado que a empresa havia classificado no Balanço Patrimonial do quarto trimestre de 2013, a constituição como Reserva Especial.

Por outro lado, no primeiro trimestre de 2014 a constituição foi tratada no Balanço Patrimonial como Reserva para Contingências, porém nas notas explicativas a classificação era de Reserva Especial.

\section{MOTIVO DA CONSTITUIÇÃO:}

Inicialmente a empresa tratou como Reserva Especial, tendo em vista que a situação financeira da organização não permitia a distribuição normal de dividendos. Em nota explicativa, a entidade justificou nos termos do artigo 202, parágrafo $4^{\circ}$ e $5^{\circ}$, da Lei 6.404/76, que em "ad referendum da AGO”, decidiu sobre a alocação do lucro líquido apurado no último exercício social da Companhia na 
conta de reserva lucros - reserva especial, optando por não destinar qualquer quantia à distribuição de dividendos no presente exercício (NEWTEL PARTICIPACOES S.A, 2014).

\section{REVERSÃO DA RESERVA:}

No que concerne ao motivo da reversão a empresa não apresentou informações em suas notas explicativas e relatórios administrativos.

\section{ANÁLISE:}

De início a classificação da reserva como "especial" estaria de acordo com a legislação, haja vista que mesmo ocorrendo lucro no período, devido a situação financeira precária da entidade, poderia afetar a distribuição de dividendos, levando a constituição da reserva supracitada.

No segundo momento, entretanto, a classificação no Balanço Patrimonial como "Reserva para Contingências" passou a demonstrar um equívoco contábil, visto que, o motivo da constituição (dificuldade na distribuição de dividendos) não se enquadra como contingência (algo que possa vir a acontecer) e sim um fato, sendo necessário, portanto, permanecer como "Reserva Especial". Além disso, outra situação incongruente com a legislação contábil, diz respeito à nota explicativa relacionada a essa constituição que apesar da mudança evidenciada no Balanço Patrimonial, continuou a ser nomeada como "Reserva Especial", ficando a dúvida se a intenção da empresa era mudar para Reserva para Contingências realmente ou se foi um erro na nomenclatura.

\section{CBCC CONTACT CENTER}

Ano da constituição da reserva:

No ano de 2006 foi constituída reserva no valor de $\mathrm{R} \$ 9.535 .000,00$ (nove milhões, quinhentos e trinta e cinco mil reais).

No ano de 2009 foi constituída reserva no valor de $\mathrm{R} \$ 1.323 .000,00$ (um milhão, trezentos e vinte e três mil reais).

\section{MOTIVO DA CONSTITUIÇÃO DA RESERVA:}

Em notas explicativas, tanto para o ano de 2006, quanto para o ano de 2009, consta que se constituiu com o saldo residual de lucros acumulados, para cobrir eventuais contingências futuras, que podem ocasionar em redução de lucros ou em surgimento de prejuízos nos períodos futuros. Reversão: 
Em 2007 parte da reserva no valor de $\mathrm{R} \$ 5.449 .000,00$ (cinco milhões, quatrocentos e quarenta e nove mil reais) foi absorvida pelos prejuízos acumulados.

Em 2008 parte da reserva no valor de $\mathrm{R} \$ 960.000,00$ (novecentos e sessenta mil reais) foi absorvida pelos prejuízos acumulados.

\section{ANÁLISE:}

Percebe-se que o motivo da constituição é genérico "eventuais contingências futuras", de forma que não possibilita uma análise mais apurada. Em 2010 ocorreu o cancelamento do registro de companhia aberta de maneira que não se conseguiu acompanhar o que ocorreu com a reserva.

\section{CIA ANTARCTICA PAULISTA - COMPANHIA BRASILEIRA DE BEBIDAS}

Ano da constituição da reserva:

A constituição ocorreu no ano de 1999, especificamente no segundo trimestre e no valor de $\mathrm{R} \$ 246.642,00$ (Duzentos e quarenta e seis mil, seiscentos e quarenta e dois reais). A empresa teve o seu registro da CVM cancelado em 18 de janeiro de 2000.

\section{MOTIVO DA CONSTITUIÇÃO DA RESERVA:}

As Notas Explicativas justificam que a reserva foi constituída após aprovação em Assembleia Geral Extraordinária, realizada em 27 de abril de 1999, aprovando a constituição da Reserva para Contingência, no valor de $\mathrm{R} \$ \mathbf{2 7 0 . 0 0 0 , 0 0}$ (Duzentos e setenta mil reais), com a finalidade de compensar, até o exercício de 2002, a diminuição do resultado decorrente da amortização do valor da maxidesvalorização cambial diferida, ocorrida no trimestre findo em 31 de março de 1999.

\section{REVERSÃO DA RESERVA:}

A reserva foi criada no segundo trimestre de 1999, e no trimestre seguinte houve a amortização da conta, levando-se a crer que houve a reversão. Consultando as Demonstrações, Notas Explicativas, Parecer dos Auditores e Relatório da Administração não se encontra nenhum comentário a esse respeito.

\section{ANÁLISE:}

Conforme o Art. 195 da Lei 6.404/76 a Companhia Antarctica Paulista cumpriu os requisitos legais dispostos, indicando a causa da possível perda, justificando sua constituição, bem como efetuando 
uma estimativa do valor. A utilização inicialmente também está conforme legislação, havendo transferência da conta Reserva para Contingências para a conta de Lucros Acumulados no primeiro trimestre após a constituição da reserva, assegurando assim a equalização da distribuição dos dividendos nos anos posteriores.

Porém, estranha-se o fato de a Assembleia ter autorizado um valor e a constituição da reserva ter sido outro valor. Outro fato que chama a atenção é o da reversão ter ocorrido de um trimestre para outro - durante o ano de 1999 -, haja vista que a previsão era de que a reversão se daria até o ano de 2002.

\section{DURATEX - DURATEX SA}

Ano da constituição:

A empresa apresentou constituição da Reserva para Contingências no ano de 1998, no valor de $\mathrm{R} \$ 25.944,00$ (vinte e cinco mil, novecentos e quarenta e quatro reais) que se manteve até o terceiro trimestre de 1999. A empresa teve o seu registro da CVM cancelado em 31 de agosto de 2009.

\section{MOTIVO DA CONSTITUIÇÃO:}

A empresa não apresentou informações específicas do motivo da constituição da reserva. Verificouse que a empresa destinou uma parte específica de suas demonstrações relatando a situação do cenário econômico, que constou no primeiro trimestre uma mudança política cambial em conjunto com uma desordem na economia causados pela previsão de uma recessão e da alta inflação, na qual a reversão desse quadro teve início com a renovação de acordos com o Fundo Monetário Internacional (FMI), que tem como finalidade oferecer ajudas financeiras aos seus países membros. Estes acordos possibilitaram a retomada do fluxo de capitais e a queda de juros e de câmbio no fim de 1999 a início do ano 2000.

\section{REVERSÃO DA RESERVA:}

No que concerne ao motivo da reversão, não se apresentou informações específicas em suas notas explicativas e relatórios administrativos. A empresa apresentou um campo com informações sobre o cenário atual da economia no qual estava inserida sem uma coligação como sendo motivo para a constituição da Reserva para Contingência. Conforme a análise detalhada dos demonstrativos, no ano de 2005, a organização atualizou as informações direcionadas para demonstrar o panorama da economia. A instituição relatou que a economia teve expectativas de melhorias e otimização no que 
concerne a política cambial, mas, novamente, sem relacionar como motivo pelo qual a empresa realizou a reversão.

\section{ANÁLISE:}

Verifica-se que a empresa não informou motivo justificável em específico da instituição da reserva. Assim, não houve cumprimento do preceituado no Art. 195 da Lei 6.404 de 1976 (Lei das Sociedades Anônimas), que regulamenta sobre a reserva, onde diz que "A proposta dos órgãos da administração deverá indicar a causa da perda prevista e justificar, com as razões de prudência que a recomendem, a constituição da reserva."

\section{CRT CELULAR - CELULAR CRT PARTICIPAÇÕES S.A.}

Ano da constituição:

No ano de 1998 apresentou-se constituição de reserva no quarto trimestre de 1998, nos anos de 2001, 2002, 2003, 2004 e 2005. Todavia, nas demonstrações do quarto trimestre de 1998, não apresentou no Balanço Patrimonial a conta de Reserva para Contingências. Nas demonstrações contábeis de 2001, 2002, 2003, 2004 e 2005 a empesa apresentou a Reserva para Contingências no valor de $\mathrm{R} \$ 11.070,00$ (Onze mil e setenta reais). A empresa teve o seu registro da CVM cancelado em 22 de fevereiro de 2006.

\section{MOTIVO DA CONSTITUIÇÃO:}

Os motivos referem-se a prováveis perdas baseadas ao processo de cisão da Companhia Riograndense de Telecomunicações - CRT e têm por finalidade garantir eventual decisão judicial acerca de ações judiciais sobre capitalizações dos exercícios sociais de 1996 e 1997 ocorridas naquela empresa.

\section{REVERSÃO DA RESERVA:}

No que concerne ao motivo da reversão, a empresa não apresentou informações específicas em suas notas explicativas e relatórios administrativos. Apresentou-se apenas o saldo zerado no campo Reserva para Contingência no Balanço Patrimonial dando a entender que houve a reversão sem mencionar o motivo. 


\section{ANÁLISE:}

No que ser refere à constituição da reserva verifica-se que a empresa seguiu os preceitos da Lei 6.404/76. No entanto, no que se refere à reversão não foram encontradas informações específicas a esse respeito.

\section{COR RIBEIRO - CORREA RIBEIRO SA COM IND}

Ano da constituição:

A empresa apresentou Reserva para Contingências desde o quarto trimestre de 2010 até o ano de 2018.

\section{MOTIVO DA CONSTITUIÇÃO:}

Em 2010 o comitê da empresa decidiu constituir Reservas para Contingências após serem excluídas de um programa do Governo Federal, que permitia ao contribuinte a liquidação de débitos de natureza tributária, vencidos até 30 de abril de 2017, de competência da Procuradoria Geral da Fazenda e da Receita Federal (REFIS).

Devido a esses motivos da exclusão da empresa, que estão sendo questionados judicialmente, a instituição decidiu criar a reserva, pois há riscos de grandes perdas decorrentes das cobranças de débitos, já que as ações judiciais ainda estão em andamento e pendentes para seu parecer final. Sendo assim, a instituição constituiu um reserva no valor de $\mathrm{R} \$ 5.336 .000,00$ (cinco milhões, trezentos e trinta e seis mil reais) que posteriormente agregou-se outros valores em função de o valor estimado da dívida ser maior e a organização ainda não ter saldo suficiente para sua integração total.

Em 2011, agregou-se a reserva $\mathrm{R} \$ 1.749 .000,00$ (um milhão, setecentos e quarenta e nove mil reais) sendo o valor presente da reserva de $\mathrm{R} \$ \mathbf{7} .085 .000,00$ (sete milhões, oitenta e cinco mil reais) e assim se permaneceu durante o ano de 2012 até o dia 30 de dezembro de 2012. No último dia do ano, a instituição reverteu-se da Reserva para Contingência $\mathrm{R} \$ 1.952 .000,00$ (um milhão, novecentos e cinquenta e dois mil reais) e, juntamente com a Reserva de Lucros, compensou prejuízos do exercício de 2012, permanecendo como Reserva para Contingência um valor de $\mathrm{R} \$ 5.133 .000,00$ (cinco milhões, cento e trinta e três mil reais). 


\section{REVERSÃO DA RESERVA:}

Ocorreu a reversão pela compensação de prejuízos dos exercícios anteriores até o quarto trimestre de 2018.

\section{ANÁLISE:}

No que se refere a sua instituição, demonstração, explicação e seus procedimentos de reversão a empresa apresentou-se adequada em todos os requisitos de forma fidedigna, possibilitando uma evidenciação adequada.

\section{VIVO - VIVO PARTICIPAÇÕES SA}

Ano da constituição:

A empresa apresentou Reserva para Contingências no início de 2006 até o final de 2008 e, novamente, se constitui a reserva no ano início de 2009 até 2011.

\section{MOTIVO DA CONSTITUIÇÃO:}

Em 2006 e 2009, período esse inicial das duas constituições, o comitê da empresa decidiu constituir Reservas para Contingências devido a valores estimados oriundos do processo de cisão da Companhia Riograndense de Telecomunicações - CRT, que tem por finalidade garantir eventual decisão judicial acerca de ações judiciais sobre capitalizações de exercícios sociais de 1996 e de 1997 ocorridas naquela empresa.

\section{REVERSÃO DA RESERVA:}

A empresa não apresentou justificativas para a reversão da reserva em seus respectivos anos em que apresenta sua reversão.

\section{ANÁLISE:}

A empresa realizou de forma correta a instituição da reserva, apresentando o motivo para a contingência de forma concisa, mas clara. Entretanto, a empresa faz a reversão sem elucidar se houve a decisão judicial que levou a constituição da reserva, não encontrando informações a esse respeito em Notas Explicativas ou outro relatório.

Por fim, apresenta-se o Quadro 1 que procura resumir a apresentação e análise dos dados. 


\section{Quadro 1 - Resumo da Análise}

\begin{tabular}{|c|c|c|c|}
\hline EMPRESA & $\begin{array}{c}\text { MOTIVOS DA } \\
\text { CONSTITUIÇÃO }\end{array}$ & REVERSÃO & ANÁLISE \\
\hline POLAR & $\begin{array}{l}\text { Compensar a diminuição do } \\
\text { resultado decorrente da } \\
\text { amortização do valor da } \\
\text { maxidesvalorização cambial. }\end{array}$ & $\begin{array}{l}\text { Houve reversão, tornando } \\
\text { possível assegurar a } \\
\text { manutenção da base de } \\
\text { cálculo dos dividendos aos } \\
\text { acionistas. }\end{array}$ & $\begin{array}{l}\text { Incongruência nos dados da } \\
\text { empresa, fragilizando e } \\
\text { deslegitimando a confiança } \\
\text { que os demonstrativos } \\
\text { deveriam trazer. }\end{array}$ \\
\hline ODERICH & $\begin{array}{l}\text { Não há explicações que } \\
\text { fundamentam a criação da } \\
\text { reserva nos demonstrativos } \\
\text { analisados. }\end{array}$ & - & $\begin{array}{l}\text { A reserva não está de acordo } \\
\text { com a legalidade; não há } \\
\text { clareza nos dados obtidos, } \\
\text { impossibilitando uma análise } \\
\text { precisa. }\end{array}$ \\
\hline SONDOTECNICA & $\begin{array}{c}\text { Cobrança judicial contra uma } \\
\text { empresa por quebra de } \\
\text { cláusula contratual; } \\
\text { manutenção do Capital de } \\
\text { Giro. }\end{array}$ & $\begin{array}{l}\text { Houve reversão e } \\
\text { concomitantemente há } \\
\text { novas constituições da } \\
\text { reserva sob diversas } \\
\text { justificativas. }\end{array}$ & $\begin{array}{c}\text { Entende-se que apenas um dos } \\
\text { motivos (manutenção do } \\
\text { capital de giro) não se } \\
\text { enquadra no que a legislação } \\
\text { propõe para constituição da } \\
\text { reserva. As reversões ocorrem } \\
\text { por motivos diferentes do que } \\
\text { levou à constituição da } \\
\text { reserva. }\end{array}$ \\
\hline NEWTEL & $\begin{array}{l}\text { A situação financeira da } \\
\text { empresa não permitia a } \\
\text { distribuição normal de } \\
\text { dividendos. }\end{array}$ & $\begin{array}{c}\text { Não há informações sobre } \\
\text { nos demonstrativos e } \\
\text { relatórios analisados. }\end{array}$ & $\begin{array}{l}\text { Verificou-se que, em um } \\
\text { primeiro momento, foi } \\
\text { classificada como Reserva } \\
\text { Especial e depois como } \\
\text { Reserva para Contingência, } \\
\text { demonstrando um equívoco } \\
\text { contábil. }\end{array}$ \\
\hline $\begin{array}{l}\text { CBCC CONTACT } \\
\text { CENTER }\end{array}$ & $\begin{array}{l}\text { Cobrir eventuais } \\
\text { contingências futuras. }\end{array}$ & $\begin{array}{c}\text { Parte das reservas foram } \\
\text { absorvidas pelos Prejuízos } \\
\text { Acumulados. }\end{array}$ & $\begin{array}{c}\text { Motivo dado para justificar a } \\
\text { constituição da reserva é } \\
\text { genérico, impossibilitando } \\
\text { uma análise mais apurada. }\end{array}$ \\
\hline $\begin{array}{l}\text { ANTARCTICA } \\
\text { PAULISTA }\end{array}$ & $\begin{array}{l}\text { Compensar a diminuição do } \\
\text { resultado decorrente da } \\
\text { amortização do valor da } \\
\text { maxidesvalorização cambial. }\end{array}$ & $\begin{array}{l}\text { Houve transferência de } \\
\text { parte do valor para a conta } \\
\text { de Lucros Acumulados e } \\
\text { no trimestre seguinte não } \\
\text { há valores na conta de } \\
\text { Reserva para Contingência, } \\
\text { sendo interpretado como } \\
\text { uma reversão. }\end{array}$ & $\begin{array}{l}\text { A constituição da reserva e } \\
\text { seus processos estão de acordo } \\
\text { com a Lei. Porém, falta } \\
\text { clareza na evidenciação da } \\
\text { reversão da reserva. }\end{array}$ \\
\hline DURATEX & $\begin{array}{l}\text { Não há fundamentação } \\
\text { precisa para a constituição da } \\
\text { reserva, apenas relatos } \\
\text { genéricos como: recessão e } \\
\text { uma alta inflação. }\end{array}$ & $\begin{array}{l}\text { Não apresenta informações } \\
\text { específicas em relatórios e } \\
\text { demonstrações. }\end{array}$ & $\begin{array}{l}\text { Não houve o cumprimento do } \\
\text { preceituado no art. } 195 \text { da Lei } \\
6.404 / 76 .\end{array}$ \\
\hline CRT CELULAR & $\begin{array}{l}\text { Prováveis perdas advindas de } \\
\text { um processo de cisão. }\end{array}$ & $\begin{array}{l}\text { Não houve informações } \\
\text { específicas sobre a } \\
\text { reversão. }\end{array}$ & $\begin{array}{c}\text { Verificou-se que a empresa } \\
\text { seguiu os preceitos legais } \\
\text { quanto à instituição da reserva, } \\
\text { mas não apresentou } \\
\text { informações específicas acerca } \\
\text { da reversão. }\end{array}$ \\
\hline
\end{tabular}




\begin{tabular}{|c|c|c|c|}
\hline COR. RIBEIRO & $\begin{array}{c}\text { Prevenir perdas decorrentes } \\
\text { de cobranças de débitos } \\
\text { judiciais que ainda estavam } \\
\text { pendentes do parecer final. }\end{array}$ & $\begin{array}{c}\text { Realizou-se a reversão para } \\
\text { compensar prejuízos dos } \\
\text { exercícios anteriores. }\end{array}$ & $\begin{array}{c}\text { Houve uma evidenciação } \\
\text { adequada de todos os } \\
\text { requisitos legais. }\end{array}$ \\
\hline VIVO & $\begin{array}{c}\text { Prováveis perdas advindas de } \\
\text { um processo de cisão. }\end{array}$ & $\begin{array}{c}\text { Não houve informações } \\
\text { específicas sobre a } \\
\text { reversão. }\end{array}$ & $\begin{array}{c}\text { Evidenciou corretamente a } \\
\text { constituição, porém realizou a } \\
\text { reversão sem elucidar se os } \\
\text { motivos que levaram a sua } \\
\text { constituição não mais existem. }\end{array}$ \\
\hline
\end{tabular}

Fonte: Dados da pesquisa

Em síntese, mediante às análises foram constatadas as seguintes observações:

- Em relação a parcela inicial da amostra (1.548 empresas), percebe-se que 15 dessas empresas fizeram menção à Reserva para Contingência em seus demonstrativos contábeis coletados da Economática ${ }^{\circledR}$, representando $0,97 \%$ da parcela inicial da amostra. Ainda, considerando as empresas que convergiram ao perfil delimitado para análise devido a inconsistências verificadas diretamente nos demonstrativos contábeis em comparação com os demonstrativos contábeis coletados da Economática ${ }^{\circledR}$, essa amostra diminui para dez empresas, representando $0,65 \%$ da parcela inicial da amostra.

Dentre as dez empresas selecionadas para compor a análise, pôde-se relatar que:

- Nove empresas não cumpriram os requisitos legais e/ou revelaram inconformidades por erro de classificação ou ainda ausência de informações, demostrando inconsistências nas evidenciações contábeis;

- Uma empresa, sendo ela a Cor Ribeiro, apresentou conformidade com os requisitos legais fundamentais para constituição e reversão da reserva, de forma concisa e fidedigna.

Dessa forma, verificou-se que $90 \%$ das empresas descritas na análise não cumpriram os requisitos legais para a constituição da reserva e/ou não evidenciam com clareza os processos contábeis que envolvam a Reserva para Contingências.

\section{CONSIDERAÇÕES FINAIS}

A atual pesquisa teve por objetivo verificar quais empresas de capital aberto constituíram e reverteram a Reserva para Contingência entre os anos de 1996 e 2019, citando os motivos e suas respectivas evidenciações, verificando nesses processos a consistência com os preceitos legais, tendo como premissa o artigo 195 da Lei das Sociedades Anônimas - Lei 6.404/76, que estabelece os critérios apropriados de reconhecimento e reversão da reserva. Para a construção da análise foi utilizado o banco de dados da Economática $^{\circledR}$, com intuito de verificar as dez empresas que apresentaram informações concernentes a essa reserva em suas demonstrações contábeis.

No que tange ao período em análise, justificado para averiguar se a Lei 11.638/07, após entrar em vigor, promoveu alguma mudança na constituição ou reversão da Reserva para Contingência, 
observou-se que a mesma não trouxe mudanças. Houveram modificações relacionadas com a organização e acesso às informações prestadas, mas não características que se figurou na Lei 11.638/07, pois em seu texto não altera quaisquer dispositivos acerca da Reserva para Contingência citada na Lei $6.404 / 76$.

Conforme os resultados obtidos, verificou-se que o objeto desse estudo ilustrou ser um uma ferramenta subutilizada nas estruturas contábeis das entidades, pois mediante as proporcionalidades em relação à amostra inicial, figurou uma parcela menor que $1 \%$ de adoção por parte das organizações.

Observou-se incoerências nas evidenciações contábeis na forma como realizaram reversões, gerando interpretações dúbias e assim afetaram a confiança que os demonstrativos deveriam representar. Tais obstáculos, no que diz respeito à clareza da informação, foram resultantes da inexistência de informações que justificassem o fundamento de sua reversão, o que implica em uma privação da compreensão por parte dos usuários das demonstrações.

Constatou-se nessa pesquisa que, das dez empresas observadas, uma empresa (Cor. Ribeiro) apresentou conformidades com a legislação. Tal entidade expôs justificativas consonantes com a criação da reserva e evidenciou de forma clara todo o processo.

Finalmente, este estudo mostra que a Reserva para Contingências não têm sido considerada instrumento essencial na contabilidade das empresas estudadas, sendo que, quando utilizam a reserva, $90 \%$ das empresas não atendem aos requisitos legais e/ou não exibem com clareza os processos contábeis que envolvam a reserva para contingências. Nesse sentido, percebe-se uma necessidade de melhoria na evidenciação contábil nas empresas de capital aberto para com essa reserva, visto que houveram contrassensos no registro dessas informações, o que consequentemente prejudica a intepretação adequada das demonstrações, inviabilizando uma análise concisa e esclarecedora.

Sugere-se como futuras pesquisas a averiguação de utilização de outras reservas de lucros. Não obstante, instiga-se estudos para verificar a existência de possíveis lacunas na legislação vigente acerca da evidenciação da reversão. 


\section{REFERÊNCIAS}

ALBUQUERQUE, Diane; FARIA, José César de. O reconhecimento da contingência nas demonstrações contábeis: provisão x reserva. XIII Encontro Latino Americano de Iniciação Científica e IX Encontro Latino Americano de Pós-Graduação, Universidade do Vale do Paraíba, São Paulo, 2009.

ANGELO, Dorival Izidoro. A importância das informações contábeis no processo decisório das empresas. Revista Sapientia - Faculdade Pio XII. São Paulo, v. 1, n. 4, p. 38-45, 2005.

ARAÚJO, Leonardo Morais. Destinação dos resultados e sua evidenciação por companhias abertas brasileiras. 2013.Trabalho de Conclusão de Curso (Bacharelado em Ciências Contábeis)

- Universidade Federal do Rio Grande do Sul, Porto Alegre, 2013.

BEUREN, Ilse Maria. Gerenciamento da informação: um recurso estratégico no processo de gestão empresarial. São Paulo: Atlas, 1998.

BLATT, Adriano. Análise de balanços: estruturação e avaliação das demonstrações financeiras e contábeis. Makron Books, 2001. E-book.

BORBA, José Alonso; POETA, Fabiana Zandonai; VICENTE, Ernesto Fernando Rodrigues. Teoria da contabilidade: uma análise da disciplina nos programas de mestrado brasileiros. Sociedade, Contabilidade e Gestão, v. 6, n. 2, 2011.

BRASIL. Lei $n=11.638$, de 28 de dezembro de 2007. Altera e revoga dispositivos da Lei no 6.404, de 15 de dezembro de 1976, e da Lei no 6.385, de 7 de dezembro de 1976, e estende às sociedades de grande porte disposições relativas à elaboração e divulgação de demonstrações financeiras. [S. I.], 28 dez. 2007.

BRASIL. Lei no 6.404, de 15 de dezembro de 1976. Dispõe sobre as sociedades por ações. Lei das Sociedades Anônimas, [S. I.], 15 dez. 1976.

B3 BRASIL BOLSA BALCÃO.Empresaslistadas. Disponível em

http://www.b3.com.br/pt_br/produtos-e-servicos/negociacao/renda-variavel/empresaslistadas.htm. Acesso em 10.10.2020.

COMISSÃO DE VALORES MOBILIÁRIOS. Informações periódicas e eventuais de companhias. Disponível em http://www.cvm.gov.br/menu/regulados/companhias/consultas/consulta-a- informacoes-decompanhias.html. Acesso em 15.10.2020.

CONSELHO FEDERAL DE CONTABILIDADE Resolução 1.180 de 24 de julho de 2009. Aprova a NBC TG 25 - provisões, passivos contingentes e ativos contingentes. Diário Oficial da União, 2009.

GELBCKE, Ernesto Rubens; SANTOS, Ariovaldo dos; IUDÍCIBUS, Sérgio de; MARTINS, Eliseu. Manual de contabilidade societária: aplicável a todas as sociedades: de acordo com as normas internacionais e do CPC. 3. ed. São Paulo: Atlas, 2018.

GIL, Antônio Carlos. Como elaborar projetos de pesquisa. 4. ed. São Paulo :Atlas, 2002 
IMPERATORE, Simone Loureiro Brum. Fundamentos da contabilidade. Curitiba: InterSaberes, 2017. 180 p. ISBN 978-85-5972-565-0. E-book.

IUDÍCIBUS, Sergio de. Análise de balanços. 11. ed. rev. e atual. São Paulo: Atlas, 2017. E-book.

IUDÍCIBUS, Sérgio de, MARION, José Carlos. Introdução à teoria da contabilidade para o nível de graduação. São Paulo: Atlas, 1999.

MATTAR, Fauze Najib; OLIVEIRA, Braulio; MOTTA, Sérgio Luís Stirbolov. Pesquisa de marketing: metodologia, planejamento, execução e análise. 7. ed. Rio de Janeiro: Elsevier, 2014. 482 p. E-book (487 p.).

MÜLLER, Aderbal Nicolas. Contabilidade básica: fundamentos essenciais. São Paulo: Pearson Prentice Hall, 2007. 128 p. E-book (128 p.). ISBN 85-7605-107-9.

NEVES, Silvério das; VICECONTI, Paulo Eduardo V. Contabilidade avançada e análise das demonstrações financeiras. 11. ed. rev. atual. e aum. São Paulo: Frase Editora, 2002. E-book (806 p.).

NEWTEL PARTICIPACOES S.A. Demonstrações financeiras dos exercícios findos em 31 de dezembro de 2013 e de 2012. Newtel Participações S.A, 2014.

NOTA EXPLICATIVA DA INSTRUÇÃO CVM № 59/86. Comissão de Valores Mobiliários.

Disponível em

http://www.cvm.gov.br/export/sites/cvm/legislacao/notas-explicativas/anexos/nota059.pdf Acesso em 10.05.2020.

PEREIRA, Larissa Lelis; SILVA, Luana Teodoro; CARVALHO, lara Medeiros. O Balanço Patrimonial e a sua relação com as Leis 11.638/07, 11.941/09 e a IFRS (Padrões Internacionais de Contabilidade). Revista Interatividade, v. 2, n. 1, p. 173-185, 2014.

RIBEIRO, A. (2010). Determinantes da política de dividendos: Evidência empírica para as empresas não financeiras cotadas na EuronextLisbon. Revista de Gestão dos Países de Língua Portuguesa, 9(1-2), 1525.

RIBEIRO, Osni Moura. Contabilidade geral fácil: Atualizado conforme as Leis $n^{\circ} 11.638 / 2007$ e $n^{\circ}$ 11.941/2019 e NBCS TGS convergentes com as Normas Internacionais de Contabilidade IFRS. 9. ed. São Paulo: Saraiva, 2013. 591 p.

VERGARA, Sylvia Constant. Projetos e relatórios de pesquisa em administração. 16. ed. São Paulo: Atlas, 2016. 145 p. E-book (145 p.). 


\section{Capítulo 6}

\section{doi $10.37423 / 220105197$}

\section{OS PRINCIPAIS IMPACTOS DA MEDIDA PROVISÓRIA 881/19 NO DIREITO EMPRESARIAL}

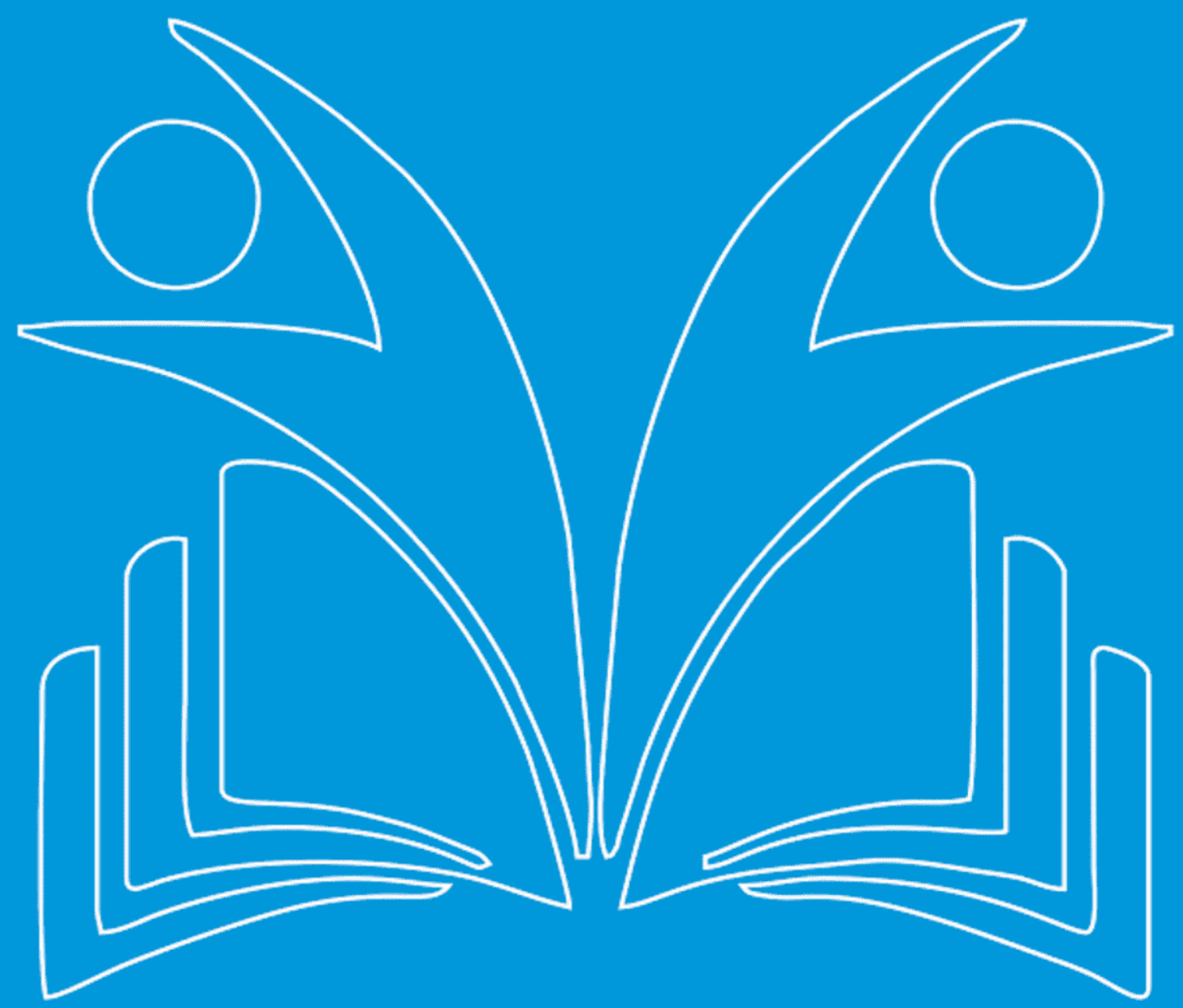


Resumo: $\mathrm{O}$ artigo pretende responder a seguinte problemática: quais foram os impactos legislativos no âmbito empresarial a partir da medida Provisória 881/19?. Nesse sentido, buscou-se discorrer sobre o contexto histórico e evolução do direito comercial/empresarial na história; conceituar os indivíduos que integram a sistema empresarial brasileiro (empresário, empresa, tipo empresarial e sócios); por fim, analisar os impactos da Medida Provisória 881/19 no âmbito empresarial, que surgiu, de acordo com o Governo Federal, pautada na necessidade de desburocratizar e instituir a declaração de direitos de liberdade econômica, sobretudo estabelecendo garantias de livre mercado. A metodologia utilizada neste artigo foi por meio de pesquisa exploratória de forma qualitativa, utilizando-se do procedimento bibliográfico e fontes interdisciplinares, bem como do método de abordagem e análise dedutiva sobre os principais impactos da medida provisória $881 / 19$ no direito empresarial. Conclui-se que as alterações realizadas no direito empresarial visaram desburocratizar, gerar liberdade ao empresário, maior facilidade para aqueles que pretendem iniciar atividade empresarial, sobretudo reduzir custos com exigências legais que anteriormente eram obrigatórias, assim, cria um cenário mais favorável ao empreendedorismo.

Palavras chave: Empreender. Desburocratização. Direito Empresarial. Liberdade. Medida Provisória. 


\section{INTRODUÇÃO}

O artigo em epígrafe tem como finalidade analisar os impactos legislativos causados no ecossistema empresarial com o advento da medida provisória 881/19, posteriormente, convertida na lei 13.874/19. Denominada e reconhecidamente difundida como a "Lei da Liberdade Econômica", para instituir a declaração de direitos de liberdade econômica e garantias de livre mercado.

Neste sentido, o cenário empresarial e econômico da última década, repercutiu diretamente nas relações jurídicas, e de forma significativa no direito empresarial, buscando atualizar a legislação ao atual modelo do empreendedorismo, consubstanciados na liberdade econômica, livre iniciativa e concorrência, propriedade privada e acessibilidade ao início das atividades empreendedoras, principalmente, levando em consideração o atual cenário econômico brasileiro. Em tempo, diversos problemas assolavam os empresários brasileiros, seja individual, seja societário, principalmente quanto a personalidade jurídica das empresas e os requisitos para desconsideração desta personalidade; especificamente o empresário individual, a necessidade de instituir um tipo empresarial que garante proteção ao patrimônio pessoal, de forma mais acessível ao empresários individuais.

Assim, a temática das legislações que buscam efetivar a liberdade e acessibilidade econômica ao direito empresarial se mostra como terreno fértil às atualizações advindas das demandas e modelos empresariais, consubstanciados em princípios constitucionais basilares da carta magna brasileira, que buscam gerar um cenário mais favorável, desburocratizado e menos oneroso aos empreendedores, para atender os anseios desta classe. Sim, efetivar atualizações e atender os anseios, pois é certo que o direito empresarial sofreu inúmeras mudanças desde seu surgimento, isso é um dado histórico entre nós. A importância social das questões econômicas e empresariais, para além da base constitucional, implicou na intervenção legislativa. Ante a tais fatores, sobrevém a problemática originária do presente trabalho, qual seja: Quais os impactos legislativos causados no direito empresarial com o advento da medida provisória $881 / 19$, posteriormente, convertida na lei $13.874 / 19$ ?

De plano, a hipótese mais imediata e convincente a ser posta para satisfação dos pressupostos metodológicos encontra-se melhor caminho na efetivação da liberdade econômica e segurança jurídica por meio de reformas legislativas, objetivando requisitos que antes eram subjetivos; gerando maior amplitude aos empresários individuais para usufruírem da responsabilidade limitada; reduzindo custos e obrigações inerentes as Companhias. Todavia, destaca-se, que serão realizadas analises das 
alterações legislativas e de algumas peculiaridades no decorrer da construção deste trabalho. Definese, portanto, uma abordagem mais técnica e pragmática próxima hermenêutica jurídica.

Colocadas essas questões, o presente artigo de trabalho tem como objetivo geral, buscar compreender os fatores que influenciaram nas alterações ocasionados ao ecossistema empresarial, conduzindo-o ao modelo de economia com menor burocracia, custos efetivos e amplitude de acesso ao mundo dos negócios.

O primeiro objetivo específico, visa contextualizar o surgimento do direito empresarial e sua evolução conjunta às atividades comerciais. O segundo objetivo específico, visa conceituar os personagens que moldam o ecossistema empresarial (empresário, empresa, empreendimento e tipo empresarial). Já o terceiro e último objetivo específico, visa analisar e adentrar com maior ênfase nas legislações que tratam do direito empresarial brasileiro e suas alterações, face a vigência da MP 881/19, convertida na Lei da Liberdade Econômica (lei 13.874/19) e os impactos causados neste ecossistema das empresas.

Este artigo cientifico se justifica, pela iniciativa de influenciar debates e análises dos aspectos estruturantes do pensamento jurídico, por uma parte, e histórico e sociológico por outra, ao mesmo tempo capaz de fortalecer o debate crítico sobre a desburocratização e efetivação das liberdades econômicas no direito empresarial, haja vista as constantes variáveis que circulam o meio político, social e jurídico no que tange a melhoria da condição econômica e social brasileira, consubstanciados na interpretação normativo-constitucional.

O presente trabalho será realizado por meio de pesquisa exploratória de forma qualitativa, utilizandose do procedimento bibliográfico e fontes interdisciplinares, bem como do método de abordagem e análise dedutiva sobre os principais impactos da medida provisória 881/19 no direito empresarial.

$\mathrm{Na}$ primeira seção, visa-se discorrer sobre o surgimento e evolução jurídica do direito comercial/empresarial, fazendo um breve relato sobre a evolução e expansão comercial, bem como a necessidade de efetivar uma legislação regulamentada pelo Estado versando, exclusivamente sobre as relações comerciais.

Partindo para a segunda seção, faz-se oportuno, portanto, compreender os conceitos dos sujeitos que integram a relação empresarial, sejam as empresas, empresários, sócios e tipos empresariais.

Por fim, na terceira e última seção, é absolutamente imprescindível falar sobre os impactos da MP 881/19 na legislação empresarial brasileira, Código Civil, e legislações especificas que tratam sobre aspectos empresariais, finalizando com breves comentários sobre a desconsideração da personalidade 
jurídica, criação da Sociedade Unipessoal Limitada em detrimento do EIRELI, e as publicações obrigatórias e novos valores para o regime simplificado de publicidades de atos societários para sociedades anônimas.

\section{CONSIDERAÇÕES SOBRE O DIREITO EMPRESARIAL NA HISTÓRIA}

Inicialmente, importante registrar que a história do direito empresarial/comercial, ou melhor, o surgimento desta área jurídica é assunto dubitável no campo das doutrinas, seja por operadores do direito, seja por filósofos, sociólogos e antropólogos. Neste sentido, afirma Rubens Requião (2012) que: "o direito comercial surgiu na Idade Média com o desenvolvimento do tráfico mercantil" (apud ALEJARRA, 2013, p. 01).

Em contrapartida, outros doutrinadores afirmam que o surgimento do direito Comercial, bem como contribuições diretas para o desenvolvimento do tipo jurídico, atravessou gerações, iniciando nos romanos, passando por fenícios, assírios, babilônicos e os gregos (ALEJARRA, 2013, p. 01). Cabe ressaltar que no Museu do Louvre, está a pedra em que foi esculpido o Código de Hamurabi, a mais de 2.000 anos a.C., contendo normas de regulavam a atividade mercantil, mas sem configurar um sistema de normas passível de ser chamado de Direito Comercial (ALEJARRA, 2013, p. 01).

Gladston Mamede (2004, apud ALEJARRA, 2013), cita o aparecimento de normas de Direito Comercial em épocas mais longínquas ainda nas regiões de Ur e Lagash, porém informando que a maciça doutrina indica como florescimento desse ramo do direito privado o aparecimento dos primeiros burgos (cidades burguesas). Ocorre que, no Império Romano, conhecido por ser o precursor do sistema romano-germânico (Civil Law), pautado estruturalmente sobre a propriedade e atividades comerciais rurais, ainda não existia autonomia do direito comercial como um segmento próprio jurídico.

Apesar de existir algumas regras de direito comercial em tempos remotos, tais regras esparsas não formaram um corpo sistematizado de normas capazes de inaugurarem a autonomia do Direito Comercial. Devido à inexistência de um poder estatal centralizado e unificado, concomitantemente ao declínio do Império Romano, inúmeras cidades/povoados foram se formando no território romano, com a influência do cristianismo e a decadência do modelo aristocrático, o modelo mercantilista foi ganhando espaço, já que as cidades/povoados formados não possuíam recursos próprios para sobreviverem; não sendo autossuficientes, acabavam necessitando de outras cidades/povoados próximos para, fomentando o comércio (ALEJARRA, 2013, p. 01). 
Ulteriormente, com o advento da classe comerciante na idade média, denominada "burgueses", em homenagem, essencialmente, às pequenas cidades chamadas de "burgos" que, estavam em ascensão face ao enfraquecimento do modelo comercial feudal onde o comércio se pautava nas trocas de mercadorias (escambo).

A partir deste momento de ruptura na idade média, ascensão das atividades econômicas, bem como do êxodo rural e a facilitação de locomoção nas vias comerciais do norte e do sul da Europa, observase o declínio do sistema feudal, gerando na sociedade uma necessidade de regulamentação do comércio para evitar a desordem, visando garantir segurança, direitos, obrigações e principalmente elaboração de uma economia de mercado conjuntamente com uma moeda.

Nesse sentido, o sistema comercial sofreu atualizações, já que o modelo de trocas "escambo" gerava algumas limitações, passando, a passos curtos, adotar o modelo de economia de mercado, bem como elaboração de uma moeda, sistema similar ao utilizado até os dias atuais. Com este modelo de mercado, a produção e comercialização foi se distanciando de ser unicamente para subsistência e troca, para se aproximar do modelo de vendas, gerando ao produtor de determinado insumo possibilidade de ampliar sua produção, mercado e variedades. Momento em que, face a reprimenda que sofriam os comerciantes pelo poder estatal, surgiu um sistema capitalista primitivo, uma nova mentalidade: "a mentalidade burguesa".

\subsection{CORPORAÇÕES DE OFÍCIO OU MERCADORES}

Em tempo, visando o crescimento comercial e econômico, bem como a busca de espaço para desenvolvimento, surgem as guildas/mesteirais ou corporações de mercadores - união de comerciantes e profissionais de diversas áreas que se uniram e para organizar e defender interesses econômicos e profissionais similares - foram muito importantes para as conquistas e espaços que os comerciantes ganharam ulteriormente. Por fim, essas associações davam assistência e segurança aos seus membros.

Foi perceptível em toda Europa Ocidental os resultados do fortalecimento das guildas e corporações mercantes, ocasionando uma oposição aos nobres e soberanos da linhagem aristocrática, principalmente na Itália e Alemanha, nas costas do Mar do Norte, especificamente nesta última surgiu a "Hansa", uma coligação de cidades mercantilistas alemãs, podendo destacar entre todas, as cidades de Hamburgo e Lubeck. Cabe ressaltar que o direito comercial aplicado às corporações era limitado 
aos membros destas, destacando seu caráter corporativo e subjetivista, semelhante aos atuais sindicatos de classes.

Alfredo Rocco (1931), aduz:

Aos costumes formados e difundidos pelos mercadores, se estes estavam vinculados; os estatutos das corporações estendiam a sua autoridade até onde chegava à autoridade dos magistrados das corporações, isto é, até os inscritos na matrícula; e, igualmente à jurisdição consular que estavam sujeitos, somente, os membros da corporação (apud ALEJARRA, 2013, p. 01).

Ocorre que, com toda a força que vinham ganhando os comerciantes, os diplomatas visando a ampliação da sua jurisdição e poder de atuação, realizaram alterações nas normativas das corporações de mercadores em busca da aplicação ampla do direito comercial, deixando de limitar as regras aos inscritos, estendendo-as a todos que praticarem atos condizentes com o comércio, delineando-se o novo conceito normativo do direito comercial/empresarial.

A abertura do direito das corporações aos demais cidadãos foi vista pela população em geral com bons olhos, visto que o direito outorgado pelo Estado era precário e com sérias tendências usurpadoras. Neste cenário, na idade média, as corporações de mercadores foram responsáveis por alavancar o Direito Comercial, bem como sua concretização como um ramo autônomo e especial do direito; principalmente na Itália, sendo considerada como berço histórico do direito comercial.

\subsection{TEORIA DOS ATOS DE COMÉRCIO - LIBERDADE COMERCIAL}

Com o advento do modelo de governo monárquico, concomitantemente às novas práticas mercantis, gerou-se um clamor em prol da objetivação do direito comercial, bem como a necessidade de regulamentação que possibilitasse organizar a estrutura comercial, definindo quem são considerados comerciantes a partir da prática mercantilista, sem exigir vínculo direto com qualquer corporação de ofício.

Assim, já na revolução Francesa, o símbolo de garantia da igualdade entre as classes sociais era a centralização e unificação do direito comercial na tutela do Estado Governante. Desta forma, não se exige mais a inscrição nas corporações de ofício para exercer efetivamente os atos comerciais, ou seja, a partir deste momento, o comerciante é todo indivíduo que exerce atos determinados atos comerciais, possibilitando a todos a oportunidade de se tornar comerciante.

Em outras palavras, o direito comercial adotou o caráter objetivista, se o indivíduo pratica atos comerciais, este é considerado comerciante, consubstanciado na ideia de igualdade e contrário à 
teoria subjetivista que, essencialmente, era seletiva, restringindo o privilégio do Direito Comercial aos inscritos nas corporações. Assim, a incorporação na legislação da Teoria dos Atos de Comércio, ocorreu com o Código Civil Francês ou, reconhecidamente como Código de Napoleão, no início do século XIX, sendo considerado o marco do tratamento jurídico da atividade mercantil, bem como pelo famoso lema liberdade, igualdade e fraternidade, entre os homens (ALEJARRA, 2013, p. 01). Na legislação brasileira, os reflexos doutrinários dos Atos de Comércio foram incorporados à legislação que versa sobre as questões mercantis, como foi o caso do Código Comercial de 1850 (BRASIL, 1850).

Antes de adentrar a evolução do direito comercial/empresarial no Brasil, é importante destacar que, não foi descrito no Código Comercial Brasileiro quais seriam os requisitos que determinavam um comerciante, sendo ulteriormente, descrito pelo decreto $\mathrm{n}-737 / 1850$, que os comerciantes, sinteticamente, eram identificados pela prática habitual e lucrativa de comercialização de bens ou mercadorias (BRASIL, 1850).

\subsection{EVOLUÇÃO JURÍDICA DO DIREITO EMPRESARIAL NO BRASIL}

Observa-se que o direito comercial brasileiro foi incorporado a partir da lei no 556/1850 (Código Comercial), deste ponto, como todo âmbito jurídico e social, não ficou estático, sofrendo inúmeras alterações até os dias atuais. Outras normativas foram surgindo, concomitantemente, realizando alterações no Código Comercial de 1850, como é o caso do decreto lei no 305 de 1967, que versa sobre a legalização dos livros de escrituração das operações mercantis, acrescentando outros livros obrigatórios para as sociedades por ações, elencados nos incisos de I a VIII do referido decreto-lei (LIMA FILHO, 2015, p. 01).

Atualmente, a legislação brasileira que versa sobre os direitos empresariais é, essencialmente, amparada pelo Código Civil Brasileiro, com capítulo dedicado ao direito das empresas. Não obstante, existe legislações específicas, decretos, provimentos e leis complementares que integram o sistema jurídico empresarial brasileiro, podendo destacar a recente medida provisória 881/19 que deu origem a lei da liberdade econômica e outras legislações presentes no cenário empresarial (LIMA FILHO, 2015, p. 01).

Neste sentido, é possível observar a mutabilidade do direito comercial/empresarial no decorrer da evolução comercial, desde o escambo (idade média) até as atividades estruturais da empresa (mundo contemporâneo), visando satisfazer as necessidades dos modelos comerciais existentes em cada época, bem como buscando cada vez maiores evoluções, como a personificação das empresas. 
Imprescindível no estudo do direito empresarial contemporâneo, compreender os conceitos básicos que circulam este meio, já que se criou na legislação brasileira, um ecossistema empresarial complexo a partir da teoria da empresa, assim, será necessário a compreensão do que se trata o empresário, empresa, sócios e tipos empresariais.

\section{TEORIA DA EMPRESA E ORDEM ECONÔMICA}

Ao se tratar de direito empresarial é de suma importância entender os conceitos daqueles que formam uma relação empresarial, ou seja, o empresário, empresa e os sócios, possibilitando a compreensão do sistema jurídico empresarial. O empresário, de acordo com o conceito jurídico previsto no artigo 966 do Código Civil de 2002, é "aquele que exerce profissionalmente atividade econômica organizada para a produção de bens ou serviços" (BRASIL, 2002). Partindo dessa premissa inicial, se torna possível observar a caracterização do empresário em três vertentes: "profissionalismo"; "uma atividade econômica organizada"; e sobretudo, "capaz de produzir bens ou serviços".

O profissionalismo de acordo com Marcio Morena Pinto, engloba outras características essenciais, veja:

Profissionalismo deve englobar os conceitos de pessoalidade, habitualidade e monopólio das informações.

A pessoalidade se traduz na qualidade do modo como se exerce a atividade, não se requerendo, necessariamente, que o empresário exerça a atividade sozinho, pois ele pode contratar empregados, mão-de-obra para a consecução da atividade, etc. E a habitualidade diz respeito à repetição diuturna da atividade empresarial, à reiteração da sua prática. Assim, não será empresário aquele que exerce, esporadicamente ou eventualmente, a venda de bens móveis, por exemplo.

O último elemento do profissionalismo é o monopólio das informações. Isso significa que o empresário detém - ou deveria deter - todo o conhecimento e informações acerca do produto ou serviço que executa, ou seja, conhece as técnicas de produção dos bens e da execução dos serviços, qualidades necessárias, matéria-prima empregada, condições de uso, nocividade, defeitos e outros (PINTO, 2013, grifo nosso)

A segunda característica do empresário é a atividade econômica organizada, ou seja, trata-se da própria empresa, o empreendimento, não se podendo confundir com estabelecimento comercial, local onde se desenvolve a atividade. Neste ponto, fica evidente a diferenciação do empresário face a empresa, haja vista que a empresa é a própria atividade organizada com finalidade econômica, obtenção de lucro; inexistindo outros requisitos que a defina, como se exige ao empresário. Por último, o empresário necessita de produzir algum tipo de produto/mercadoria, ou, realizar prestação de serviços. 
Cabe ressaltar que o próprio artigo 966, parágrafo único do CC/02 preconiza uma ressalva aos casos de profissionais intelectuais (advogados, engenheiros, médicos, dentistas, escritores, atores, entre outros), embora estes profissionais também produzam riqueza e suas atividades sejam econômicas e organizadas, não são definidos como empresários. Corroborando ao descrito, o enunciado 194 da III Jornada de Direito Civil do Conselho da Justiça Federal (CJF) preconiza: "Os profissionais liberais não são considerados empresários, salvo se a organização dos fatores de produção for mais importante que a atividade pessoal desenvolvida" (PINTO, 2013, p. 01, grifo nosso).

A título de exemplo, o fator de produção é mais importante do que a atividade pessoal desenvolvida quando o profissional liberal resolve expandir seu negócio e passa a contratar outros profissionais visando expandir sua clientela, bem como desenvolver sua própria rede de negócios. Nos dias atuais podemos identificar inúmeras empresas odontológicas que utilizam esse modelo como a Odonto Company e Oral Sin.

Ademais o empresário pode tanto ser pessoa física quanto pessoa jurídica, in verbis:

O empresário pode ser pessoa física ou jurídica, empresário individual ou sociedade empresarial. Desse modo, não se confunde empresário com os sócios de uma sociedade empresária, já que estes podem ser empreendedores ou investidores, enquanto o empresário é a própria sociedade, um sujeito de direito com personalidade autônoma em relação aos sócios (NASCIMENTO, 2018, p. 01).

Deve-se desde logo acentuar que os sócios da sociedade empresária não são empresários. Quando pessoas (naturais) unem seus esforços para, em sociedade, ganhar dinheiro com a exploração empresarial de uma atividade econômica, elas não se tornam empresárias. A sociedade por elas constituída, uma pessoa jurídica com personalidade autônoma, sujeito de direito independente, é que será empresária, para todos os efeitos legais.

Deste modo:

Os sócios da sociedade empresária são empreendedores ou investidores, de acordo com a colaboração dada à sociedade (os empreendedores, além de capital, costumam devotar também trabalho à pessoa jurídica, na condição de seus administradores, ou as controlam; os investidores limitam-se a aportar capital). As regras que são aplicáveis ao empresário individual não se aplicam aos sócios da sociedade empresária - é muito importante apreender isto (NASCIMENTO, 2018. Página única).

Assim, observado a definição elucidada no art. 966 do Código Civil/2002, bem como da análise realizada neste tópico, é possível observar as características e premissas que permitem identificar a figura da empresa e empresário, essenciais para compreensão do sistema jurídico empresarial brasileiro e seus tipos empresariais. 


\subsection{DA EMPRESA}

As empresas podem ser classificadas por sua atividade econômica; sua constituição jurídica e; titularidade do capital. Quanto sua atividade econômica é subdividida em setores, sendo eles: setor primário (exploração de recursos naturais, a exemplo das atividades agropecuárias, agrícolas e pesqueiras); setor secundário (atividades voltadas à transformação/exploração de matérias-primas, como as indústrias e a construção civil); por fim, o setor terciário (são as empresas voltadas à prestação de serviços ou comércio).

O segundo ponto dentre a classificação das empresas, trata-se da constituição jurídica, ou seja, o formato em que elas foram constituídas, podendo ser empresas individuais, quando pertencem a um único sócio; empresas societárias, aquelas que são constituídas por mais de uma pessoa/sócio (Sociedades anônimas "S/A", Responsabilidade Limitada "Ltda" e etc); e por fim, classificação quanto a titularidade do capital social, ou seja, empresas privadas, empresas públicas ou de economia mista, sendo as primeiras aquelas que o capital social é proveniente de particulares, enquanto a segunda tem como controlador a figura do Estado, e a terceira, o capital dividido entre particulares e o Estado, denominada como empresas de economia mista.

Em relação a constituição jurídica societária das empresas, o Código Civil Brasileiro prevê a exigência de estabelecer um tipo empresarial dentre os existentes, quais sejam: Sociedade Simples; Sociedade Limitada (LTDA); Sociedade em nome Coletivo; Sociedade em Comandita Simples; Sociedade em Comandita por Ações; Sociedades Anônimas (S/A); Sociedades em Conta de Participação; Sociedade de Advogados e por fim a mais recente Sociedade Unipessoal Limitada (SLI), inserida no ordenamento jurídico pela lei 14.195 de 26 de agosto de 2021.

Definido o tipo empresarial que se enquadra nas necessidades do empreendimento; do faturamento; porte ou tamanho; e dos sócios, a legislação empresarial exige realizar o registro da empresa nos órgãos competentes, sendo na esfera federal, o Departamento Nacional do Registro Empresarial e Integração (DREI), e na esfera estadual, as juntas comerciais.

A exigência do registro nos órgãos competentes está prevista no artigo 1ㅇ da lei 8.934/94, responsável por regulamentar os registros públicos de empresas mercantis e atividades afins. Assim, de forma sintética e objetiva, ficam demonstrados os conceitos básicos de empresário, empresas e tipos societários/empresarial, possibilitando mais adiante demonstrar as alterações sofridas no direito 
empresarial brasileiro devido as necessidades dos novos modelos comerciais, sobretudo, diante do cenário pandêmico do COVID-19.

\subsection{DA ORDEM ECONÔMICA CONSTITUCIONAL: ALICERCES DA LIBERDADE ECONÔMICA}

Com o advento da lei 13.874/19, denominada, também, como Lei da Liberdade Econômica, foram promovidas inúmeras discussões voltadas às questões de Ordem Econômica Constitucional, previstas no artigo 170 e seguintes da CF/88. Como bem denota Gustavo Ribeiro Rocha, "em que pese a inexistência da pretensão de um estudo aprofundado em Direito Constitucional, cumpre notar que, naqueles artigos, especialmente no art. 170, há importantes princípios, relacionados à atividade empresarial, consagrados pela Constituinte de 1988" (ROCHA, 2020. p. 01).

Nesse sentido, os princípios da propriedade privada e livre concorrência, previstos no artigo 170, incisos II e IV, da CF/88, fundamentam a instituição da declaração de direito e liberdade econômicas, bem como garantias de livre mercado, que preambularmente, são os objetivos da Medida Provisória 881/19, posteriormente, convertida na Lei da Liberdade Econômica.

Consubstanciados pelos princípios descritos, abalizados a partir de 1988, o direito empresarial sofreu recentes alterações, principalmente no decorrer de 2019, mas que ainda estão sendo realizadas, em prol do incentivo à iniciativa privada e à liberdade econômica, assim, podemos passar à análise destas alterações e demonstrar nossa legislação atual.

\section{O DIREITO EMPRESARIAL A PARTIR DA MP 881/19: CÓDIGO CIVIL E LEGISLAÇÕES ESPECÍFICAS}

A legislação empresarial brasileira possui fundamento no Código Civil, especificamente no Livro II "do direito de empresa", artigo 966 e seguintes. Ocorre que, inúmeras outras leis auxiliam a regulamentação do universo empresarial no Brasil, podendo destacar as leis 13.874/19; 13.818/19; e 14.195/21, entre outras, provenientes da MP 881/19. Nestas leis mencionadas, pode-se perceber que o ano de 2019 foi um marco para o direito empresarial, com mudanças significativas no modo operandis do empresariado brasileiro, já que estas legislações foram elaboradas no referido ano, com exceção da lei 14.195/21 que surgiu posteriormente, porém com respaldo na MP 881/19 e na lei 13.874/19 (lei da liberdade econômica) (LOPES; SANTOS; LEÃO, 2020. p. 01).

A lei 13.874/19, também conhecida como "lei da liberdade econômica" surgiu com a necessidade de instituir a Declaração de Direitos de Liberdade Econômica, bem como estabelecer garantias de livre mercado, conforme se observa no seu preâmbulo. Não obstante a lei $13.818 / 19$, respaldada no 
fundamento da garantia de livre mercado, altera a lei 6.404/76 que trata, especificamente, sobre as sociedades anônimas (LPOES; SANTOS; LEÃO, 2020).

Ulteriormente, surgiu a lei 14.195/21, também consubstanciada nas garantias de livre mercado para dispor, conforme descreve seu preâmbulo:

Sobre a facilitação para abertura de empresas, sobre a proteção de acionistas minoritários, sobre a facilitação do comércio exterior, sobre o Sistema Integrado de Recuperação de Ativos (Sira), sobre as cobranças realizadas pelos conselhos profissionais, sobre a profissão de tradutor e intérprete público, sobre a obtenção de eletricidade, sobre a desburocratização societária e de atos processuais e a prescrição intercorrente [...] (BRASIL, 2021).

Assim, de acordo com Fernando Brandariz (2019, p. 01) “O ano de 2019 foi bastante movimentado na área do Direito Empresarial com a promulgação da Lei 13.874/2019, conversão da Medida Provisória 881/2019, a chamada Lei da Liberdade Econômica". O curso do ano de 2019 ocorreram alterações legislativas relevantes com o propósito de facilitar a rotina empresarial no Brasil. Em abril de 2019, foi promulgada a Lei 13.818/2019, que alterou as normas de publicações previstas na Lei no 6.404/1976 (Lei das Sociedades Anônimas), com eficácia determinada para 1 de janeiro de 2022 (LOPES; SANTOS; LEÃO, 2020. p. 01).

Nota-se que os legisladores brasileiros se esforçaram para adaptar o direito empresarial ao cenário mais atual do mercado, visando atualizar a legislação para melhor atender os anseios dos empresários contemporâneos, sobretudo, trazer maior segurança jurídica ao empresariado, enfatizando o caráter personalíssimo das empresas; liberdade econômica e garantias de livre mercado.

\subsection{LEI 13.874/19: PERSONIFICAÇÃO DA EMPRESA, EFETIVANDO A AUTONOMIA DAS PARTES.}

Inúmeras foram as alterações no código civil ocasionados pela lei da liberdade econômica, efetivando a segurança jurídica ao elaborar no direito das empresas um ecossistema de independência e liberdade face aos empresários, sócios e administradores.

A lei da liberdade econômica emolda segurança jurídica efetivando a objetivação da personalidade das empresas, conforme se abstrai do art. 7ำ, incluindo ao artigo 49-A do Código Civil de 2002 que "a pessoa jurídica não se confunde com os seus sócios, associados, instituidores ou administradores" (BRASIL, 2002). Ademais, o parágrafo único disciplina que "a autonomia patrimonial das pessoas jurídicas é um instrumento lícito de alocação e segregação de riscos, estabelecido pela lei com a finalidade de estimular empreendimentos, para a geração de empregos, tributo, renda e inovação em benefício de todos (BRASIL, 2002), enfatizando personalização da empresa, face ao empresário. 
Concomitantemente, foi inserido, ainda, o §7ำ no artigo 980-A do Código Civil, preconizando que "somente o patrimônio social da empresa responderá pelas dívidas da empresa individual de responsabilidade limitada, hipótese em que não se confundirá, em qualquer situação, com o patrimônio do titular que a constitui, ressalvados os casos de fraude (BRASIL, 2002).

Neste contexto, a regra não é absoluta, existindo situações que levam a desconstituição da personalidade jurídica, essas situações acontecem por abuso da personalidade jurídica caracterizado pelo desvio de finalidade ou pela confusão patrimonial, conforme aduz o artigo 50 do Código Civil. Quanto ao desvio de finalidade da empresa, previsto no art. 50 do Código Civil, a lei da liberdade

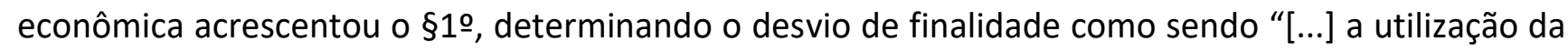
pessoa jurídica com o propósito de lesar credores e para a prática de atos ilícitos de qualquer natureza" (BRASIL, 2002). Não obstante, também foi inserido, o §2ำ neste mesmo artigo, determinando o que se trata a confusão patrimonial:

Art. $50[\ldots]$

§2을 Entende-se por confusão patrimonial a ausência de separação de fato entre os patrimônios, caracterizada por:

I - Cumprimento repetitivo pela sociedade de obrigações do sócio ou do administrador ou vice-versa

II - Transferência de ativos ou de passivos sem efetivas contraprestações, exceto os de valor proporcionalmente insignificante; $\mathrm{e}$

III - outros atos de descumprimento da autonomia patrimonial (BRASIL, 2002).

Os $\S \S 1$ e 2ㅇa acrescentados ao artigo 50 do Código Civil, visa estabelecer maior segurança jurídica, já que determinou um rol objetivo dos requisitos que ocasionam a desconsideração da personalidade jurídica, efetivando a autonomia patrimonial entre a sociedade e os sócios, bem como enfatizou ser um instrumento que, essencialmente, atende à livre iniciativa e ao desenvolvimento econômico.

A desconsideração ocorrida pelo descumprimento dos requisitos previstos no art. 50, §§ 1ㅇ e 2 o e seus incisos do Código Civil, caracterizam a denominada teoria maior da desconsideração da personalidade jurídica, que anteriormente já era aplicada, todavia, agora vigora de forma explícita e objetiva, quanto às relações do direito civil e empresarial/comercial, já que na seara trabalhista existem inúmeras controvérsias face a aplicabilidade da teoria maior.

Neste sentido, partindo do pressuposto inicial de que a lei 13.874/19 será observada na aplicação e interpretação do direito civil, empresarial, econômico, urbanístico e do trabalho nas relações jurídicas

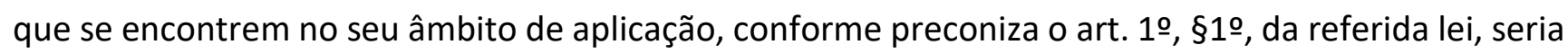


possível concluir a admissibilidade da teoria maior de desconsideração no âmbito processual trabalhista.

De plano, é possível identificar em inúmeras decisões recentes no âmbito trabalhista que, na justiça do trabalho ainda prevalece a teoria menor da desconsideração, o que influencia diretamente na estrutura empresarial, gerando controvérsias ao que dispõe a lei 13.874/19, já que esta surge para garantir a personificação da empresa, ou seja, objetivar a personalidade jurídica, desvinculando-a do empreendedor, pessoa física, veja as decisões:

AGRAVO DE PETIÇÃO. INCIDENTE DE DESCONSIDERAÇÃO DA PERSONALIDADE JURÍDICA INSTAURADO PERANTE O JUÍZO DE 1ㅇ GRAU. A legislação civil orientase por duas teorias distintas ao fixar os pressupostos para a despersonalização da pessoa jurídica: a Teoria Maior - agasalhada pelo art. 50 do Código Civil, que traz como exigência para a desconsideração o abuso de personalidade - e a Teoria Menor da Desconsideração - adotada pelo art. 28 e seu parágrafo quinto do Código de Defesa do Consumidor. Esta última teoria - que sustenta que basta a simples insuficiência patrimonial da personalidade jurídica para a decretação da responsabilidade dos sócios - é a que vem sendo aplicada no processo do trabalho, em face da similitude de princípios que orientam este ramo especializado do Direito e o CDC, em especial o da proteção ao hipossuficiente.

(TRT-10 - AP: 0000897-76.2018.5.10.0104 DF. Data de Julgamento 29/09/2021, Data de Publicação: 07/10/2021) (BRASIL, 2021, grifo nosso)

EXECUÇÃO. DESCONSIDERAÇÃO DA PERSONALIDADE JURÍDICA DA EXECUTADA. REDIRECIONAMENTO DA EXECUÇÃO EM FACE DO SÓCIO. Em razão do princípio da proteção ao hipossuficiente, adota-se a teoria menor da desconsideração da personalidade jurídica (art. 28, § 5o, do (DC), na qual a simples obstrução pela pessoa jurídica da obtenção do crédito pelo exequente enseja o alcance do patrimônio dos sócios para satisfazer a execução. Assim, a evidência da ausência de patrimônio da empresa executada para arcar com os créditos devidos ao exequente é circunstância bastante para autorizar o direcionamento da execução em face de seu sócio." (TRT18, AP-001102688.2018.5.18.0017, REL. SILENE APARECIDA COELHO, 3a TURMA, 23/02/2021); (TRT18, AP - 0011581-23.2018.5.18.0012, Rel. PAULO PIMENTA, 2a TURMA, 09/10/2021) (BRASIL, 2021, grifo nosso)

Conforme se observa dos acórdãos acima descritos, 0

Neste ínterim, a teoria menor de desconsideração não só é adotada pelo direito do trabalho, como, também, pelo direito do consumidor, consubstanciado na hipossuficiência de uma das partes em relação a outra, ocasionando relação jurídica assimétrica. Partindo desta premissa, o que dispõe no Código do Consumidor no art. 28, §5으, é a fundamentação da teoria menor da desconsideração, considerando a hipossuficiência de uma das partes que, de forma analógica o empregado, também, é considerado hipossuficiente na relação do contrato de trabalho; se aplica subsidiariamente a 
legislação consumerista no tocante a desconsideração da personalidade jurídica, no direito do trabalho.

Em contrapartida, ao se tratar de direito civil e direito empresarial presume-se relação de paridade entre os contratantes, o que as torna incompatíveis com a hipossuficiência do trabalhador nas relações de trabalho. Tal circunstância afasta a incidência obrigatória dos requisitos do art. 50 do CC, com alterações da Lei 13.874/19, como única forma de desconsiderar a personalidade jurídica no direito do trabalho.

Portanto, observa-se que a personificação da empresa se concretizou no cenário jurídico brasileiro, essencialmente, se fortaleceu nas relações cíveis e empresariais, mantendo, ainda, a teoria menor da desconsideração nas relações consumeristas e trabalhistas, visto a hipossuficiência do trabalhador e do consumidor, e quanto ao direito civil e empresarial, presumindo a equivalência das partes, prevalece a teoria maior da desconsideração, nos termos do art. 50, §§ 1으 e 2 음 do Código Civil.

\subsection{LEIS 13.874/19 E 14.195/21: SOCIEDADE LIMITADA UNIPESSOAL (SLU) FACE AO EMPRESÁRIO} INDIVIDUAL DE RESPONSABILIDADE LIMITADA (EIRELI)

Outras inovações que adentraram o direito empresarial neste momento de pandemia com o advento das leis 13.874/19 e 14.195/21 foi a extinção da figura do empresário individual de responsabilidade limitada (EIRELI) em prol do surgimento da sociedade limitada unipessoal (SLU), que essencialmente, tratam sobre o empresário individual ou único sócio.

A EIRELI surgiu em 2011 por meio da lei 12.441, possibilitando ao empresário individual criar uma personalidade jurídica desvinculada do seu patrimônio pessoal, ou seja, aplicação da responsabilidade limitada ao empresário individual. Ocorre que para criação de uma EIRELI, a legislação exigia que o empresário integralizasse capital social mínimo não inferior a 100 vezes o salário mínimo vigente, ocasionando seletividade, visto que o valor é considerado voluptuoso sob o aspecto social brasileiro, já na SLU inexiste exigência de valor mínimo do capital social e ainda protege o patrimônio pessoal do sócio.

Com isto, a lei 14.195/21 apresentou a Sociedade Limitada Unipessoal (SLU) em detrimento da EIRELI que, essencialmente, possui a mesma finalidade de separar o patrimônio pessoal do patrimônio da empresa, evitando a confusão destes em eventual responsabilidade patrimonial da empresa, senão pelos meios de desconsideração de personalidade jurídica tratado no tópico anterior. Desta forma, as EIRELI's existentes, estão sendo transformadas em SLU's, independentemente de alteração no ato 
constitutivo da empresa, conforme prescreve o artigo 41 da lei 14.195/21: “Art. 41. As empresas individuais de responsabilidade limitada existentes na data da entrada em vigor desta Lei serão transformadas em sociedades limitadas unipessoais independentemente de qualquer alteração em seu ato constitutivo" (BRASIL, 2021).

Ademais, outro importante aspecto em vantagem à SLU se refere a quantidade de empresas que podem ser criadas pelo mesmo sócio, haja vista que a pessoa natural que constituísse uma EIRELI só poderia figurar em uma única empresa desta modalidade, conforme dispõe o art. 980-A, § 2 o do Código Civil, fato que não ocorre com a SLU, possibilitando a um único sócio figurar em mais de uma empresa desta modalidade.

Cabe mencionar que aqueles que são cadastrados como Microempreendedores Individuais (MEI) ativos estão vedados de realizar abertura de uma SLU, sendo necessário o cancelamento do cadastro do MEI para abertura da Sociedade Limitada Unipessoal. No que tange aos cadastros e regras que cerceiam uma sociedade Limitada Unipessoal, devem ser obedecidas àquelas estabelecidas no capítulo do Código Civil específico sobre as sociedades limitadas, artigos 1.052 e seguintes, bem como as mesmas condições cadastrais.

Desta forma, a partir da MP 881/19 convertida na lei 13.874/19 visando um cenário empresarial consubstanciado nos princípios do livre mercado e liberdade econômica, estas alterações visam garantir maior amplitude aos empresários individuais e proteção ao patrimônio pessoal.

\subsection{LEI 13.818/19: PUBLICAÇÕES OBRIGATÓRIAS E NOVOS VALORES PARA O REGIME SIMPLIFICADO DE PUBLICIDADES DE ATOS SOCIETÁRIOS PARA SOCIEDADES ANÔNIMAS.}

A lei 13.818/19 surgiu com a necessidade de atualizar as regras contidas na legislação das sociedades anônimas (lei 6.404/76), bem como favorecer os novos modelos empresariais deste tipo empresarial, principalmente no tocante as publicações obrigatórias e quanto a ampliação do valor máximo admitido de patrimônio líquido para que a sociedade anônima faça jus ao regime simplificado de publicidades de atos societários, conforme descreve o preâmbulo da referida lei.

No que se refere as publicações obrigatórias dos atos da sociedade anônima anteriormente à vigência da lei 13.818/19, deveriam ser realizadas por meio do Diário Oficial. Com as novas disposições implementadas pela lei 13.818/19, foi alterada a redação do art. 289 da lei 6.404/76, que deixou de determinar a publicação na imprensa oficial, exigindo que sejam publicados, de forma resumida, em jornal de grande circulação na sede da companhia e com divulgação simultânea da íntegra dos 
documentos no site deste mesmo jornal, destacando que os documentos devem ter certificação digital da autenticidade emitida por autoridade certificadora credenciada no âmbito da Infraestrutura de Chaves Públicas Brasileiras (ICP-Brasil), nos termos do art. 1으, inciso I da lei 13.818/19.

Esta alteração no dispositivo legal insurge com o objetivo de reduzir os gastos/custos das Companhias com divulgação em diário oficial, visto que desobriga a publicação em órgão oficial da União ou do Estado ou do Distrito Federal, exigindo, tão somente, que seja realizada em jornal de grande circulação na localidade em que está associada a sede da companhia.

Não obstante, as alterações também visam propiciar aos processos de convocação dos sócios e publicações obrigatórias, maior celeridade, já que basta contratar os serviços de um jornal de grande circulação local e realizar a publicação. Ao se tratar de publicações de demonstrações financeiras, a regra para publicação de forma resumida observar os requisitos estabelecidos no inciso II do artigo 1 으 da lei $13.818 / 19$, quais sejam:

Art. 1‥ [...]

Inciso II: "deverá conter, no mínimo, em comparação com os dados do exercício social anterior, informações ou valores globais relativos a cada grupo e a respectiva classificação de contas ou registros, assim como extratos das informações relevantes contempladas nas notas explicativas e nos pareceres dos auditores independentes e do conselho fiscal, se houver (BRASIL, 2019).

Importante frisar que a vacatio legis do artigo acima descrito será até 31 de dezembro de 2021, passando a vigorar a partir de 1을 de janeiro de 2022. Outro tópico importante modificado pela lei 13.818/19, foi o artigo 294 da lei 6.404/76, que versa sobre o valor máximo do patrimônio líquido da companhia e quantidade de acionistas para ser beneficiada com o regime simplificado de publicidade dos atos societários, que passou de $\mathrm{R} \$ 1.000 .000,00$ (um milhão de reais) para $\mathrm{R} \$ 10.000 .000,00$ (dez milhões de reais), bem como ter menos de 20 (vinte) acionistas, sendo que esta parte da lei passou a vigorar a partir da data de publicação.

Ocorre que, uma nova atualização deste valor ocorreu por meio da lei complementar 182/2021, elevando-o até a quantia de $\mathrm{R} \$ 78.000 .000,00$ (setenta e oito milhões de reais), sobretudo, deixou de exigir número mínimo de acionistas; esta regra que permanece em vigência até no presente momento. Entende-se que as alterações legislativas foram acertadas, no contexto geral, por direcionar o âmbito empresarial aos ideais de liberdade e acessibilidade, adotando efetivas medidas legais na busca de garantir a liberdade econômica. 
De maneira geral, o Poder Público entendeu as necessidades dos empresários e das empresas, bem como a importância econômica e social que estes personagens possuem na sociedade por gerar renda e emprego, e realizou alterações legislativas advindas da MP 881/19, posteriormente convertida na Lei da Liberdade Econômica, que direciona o direito empresarial ao modelo atual dos negócios e da realidade brasileira, moldado na desburocratização, livre iniciativa e redução de custos efetivos, para criar um cenário mais atraente e favorável à atividade empresarial.

\section{CONSIDERAÇÕES FINAIS}

No decorrer deste trabalho, demonstrou-se que, o direito comercial adentra milhares de anos na história da evolução humana, retratando cada momento comercial vivenciado na sociedade, até o presente momento.

Com base na evolução social, econômica e observância dos princípios constitucionais relativos à Ordem Econômica, foi possível implementar mudanças significativas na legislação, tal como no Código Civil e outras legislações específicas do universo empresarial, adotando medidas estimulantes à iniciativa privada, robustecidas por segurança jurídica. A segurança jurídica, se retrata principalmente nos requisitos objetivos que admitem a desconsideração da personalidade jurídica, respeitando a autonomia das sociedades e das partes, mas que ao mesmo tempo previne a fraude ou abusos cometidos por um dos sócios ou pelos sócios, se utilizando da pessoa jurídica.

Em tempo, demonstrou a inovação trazida pela lei $13.874 / 19$, denominada Sociedade Limitada Unipessoal (SLU), que aposenta o Empresário Individual de Responsabilidade Limitada (EIRELI), elaborada com intuito de incentivo ao empreendedorismo e efetivação da livre iniciativa. Indubitavelmente, será uma forte ferramenta de incentivo ao empreendedorismo no Brasil, todavia, por si só não conseguirá atingir esses resultados, sendo necessário adoção de outras medidas e legislações para concretizar tais objetivos.

Com esta mesma ideia de liberdade econômica e incentivo ao empreendedorismo, foi criada a lei 13.818/19, que versa sobre as publicações obrigatórias e os novos valores que admitem as companhias fazerem jus ao regime simplificado de publicidades de atos societários, visando reduzir as atos obrigatórios a serem publicados pelas sociedades anônimas e a retirar a exigência de serem realizados por meio do diário oficial, sobretudo, aumentou o valor mínimo do capital social exigido para se valer deste regime simplificado. Tais fatos, visam diminuir os gastos das companhias e gerar liberdade para publicar em meios de comunicação locais com grande circulação. 
O objetivo central foi demonstrar que estas alterações legislativas evidenciam a tentativa do legislador em incorporar com maior efetividade ao direito empresarial, os princípios da liberdade econômica e livre concorrência, bem como estabelecer garantias de livre mercado para atender os anseios dos novos modelos empresariais. sobretudo

Portanto, pode-se concluir que a Lei 13.874/19 gerou impactos legislativos essencialmente significativos, alterando o Código Civil Brasileiro no que tange ao direito das empresas, sobretudo moldou o direito empresarial a partir da lei 13.874/19, em prol de tornar mais acessível e proporcional à realidade social dos brasileiros que pretendem iniciar seus negócios e gerar um cenário futuro mais favorável ao empreendedor. 


\section{REFERÊNCIAS}

ALEJARRA, Luis Eduardo Oliveira. A História e evolução do Direito Empresarial. Jus. 2013. Disponível em: https://jus.com.br/artigos/23971/historia-e-evolucao-do-direito-empresarial. Acesso em: 08 nov. 2021.

BRANDARIZ, Fernando. Direito Empresarial ganhou avanços com a Lei da Liberdade Econômica. Consultor Jurídico. 2019. Disponível em: https://www.conjur.com.br/2019-dez-22/direitoempresarial-avancos-lei-liberdade-economica. Acesso em: 08 nov. 2021.

BRASIL. Lei no 556, de 25 de junho de 1850. Presidência da República. Casa Civil. Subchefia para Assuntos Jurídicos. Disponível em: http://www.planalto.gov.br/ccivil_03/leis/lim/lim556.htm. Acesso em: 08 nov. 2021.

. Decreto no 737, de 25 de novembro de 1850. Presidência da República. Casa Civil. Subchefia para Assuntos Jurídicos. Disponível em:

http://www.planalto.gov.br/ccivil_03/decreto/historicos/dim/DIM0737.htm. Acesso em: 08 nov. 2021.

. Lei no 14.195, de 26 de agosto de 2021. Diário oficial da união. Publicado em: 27/08/2021 | Edição: 163 | Seção: 1 | Página: 4. Órgão: Atos do Poder Legislativo. Disponível em: https://www.in.gov.br/en/web/dou/-/lei-n-14.195-de-26-de-agosto-de-2021-341049135. Acesso em: 08 nov. 2021.

. Lei no 13.818, de 24 de abril de 2019. Presidência da República. Casa Civil. Subchefia para Assuntos Jurídicos. Disponível em: http://www.planalto.gov.br/ccivil_03/_ato20192022/2019/lei/L13818.htm. Acesso em: 08 nov. 2021.

. Tribunal Regional do Trabalho (10ạ região). Agravo em Petição no 000089776.2018.5.10.0104 DF. Data de Julgamento 29/09/2021, Data de Publicação: 07/10/2021. Disponível em:

https://pje.trt10.jus.br/jurisprudencia/ServletVisualizaDocumento;jsessionid=ChqRCSqbRLPafSAt2ilHzFXPE7fSv-kOu929FQn?nomeArquivo=0000897-

76.2018.5.10.0104.html\&tipoDownload=inline\&tipoConteudo=text_html;charset=utf-8. Acesso em: 08 nov. 2021.

- Tribunal Regional do Trabalho (18a região). Agravo em Petição no 001102688.2018.5.18.0017, REL. SILENE APARECIDA COELHO, 3a TURMA, 23/02/2021. Disponível em: https://sistemas2.trt18.jus.br/solr/pesquisa?q=\%28teoria+menor+da+desconsidera\%C3\%A7\%C3\%A 30\%29+\&x=0\&y=0\&sort=data_aprox+desc\%2C+score+desc\&todas=\&expressao=\&qualquer=\&nenhu $\mathrm{ma}=\& \mathrm{q} 3=$ teoria+menor+da+desconsidera\%C3\%A7\%C3\%A3o. Acesso em: 08 nov. 2021.

LIMA FILHO, Eujecio Coutim. Direito comercial: da evolução histórica à moderna teoria da empresa. Jus. 2015. Disponível em: https://jus.com.br/artigos/39132/direito-comercial-da-evolucao-historicaa-moderna-teoria-da-empresa. Acesso em: 08 nov. 2021.

LOPES, A. K.; SANTOS, M. C. C. A.; LEÃO, A. G. Alterações legislativas marcaram o ano de 2019 para empresas. Consultor Jurídico. 2019. Disponível em: 
https://www.conjur.com.br/2020-jan-09/direito-societario-mudancas-legislativas-marcaram-ano2019. Acesso em: 08 nov. 2021.

NASCIMENTO, Francisco José Alves do. Empresário: Conceito e Aspectos Básicos. Jus. 2018. Disponível em: https://jus.com.br/artigos/65449/empresario-conceito-e-aspectos-basicos. Acesso em: 08 nov. 2021.

PINTO, Marcio Morena. Quem é o empresário na legislação brasileira? Jusbrasil. 2013. Disponível em: https://marciomorena.jusbrasil.com.br/artigos/121943993/quem-e-o-empresario-na-legislacaobrasileira. Acesso em: 08 nov. 2021.

ROCCO, Alfredo. Princípios do Direito Comercial. São Paulo: Saraiva, 1931.

ROCHA, Gustavo Ribeiro. Ordem Econômica Constitucional, Lei n. 13.874/2019 e Direito Comercial Brasileiro. 2020. Disponível em: https://ribeirorocha.com.br/artigo/ordem-economica-constitucionallei-n-13-874-2019-e-direito-comercial-brasileiro/. Acesso em: 08 nov. 2021. 


\section{Capítulo 7}

\section{doi $10.37423 / 220105199$}

\section{ENTRE A CRUZ E A ESPADA: A POPULAÇÃO LGBTQI+ E AS ELEIÇÕES DE 2018}

Paulo de Tarso Xavier Sousa Junior

Brenna Galtierrez Fortes Pessoa

João Caio Silva Castro Farrekra

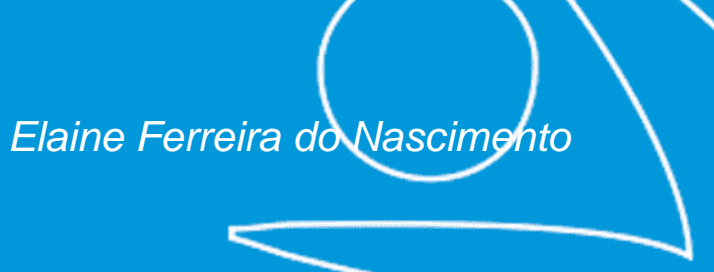

Liana Maria Ibiapina doMonte

Giorge André Lando

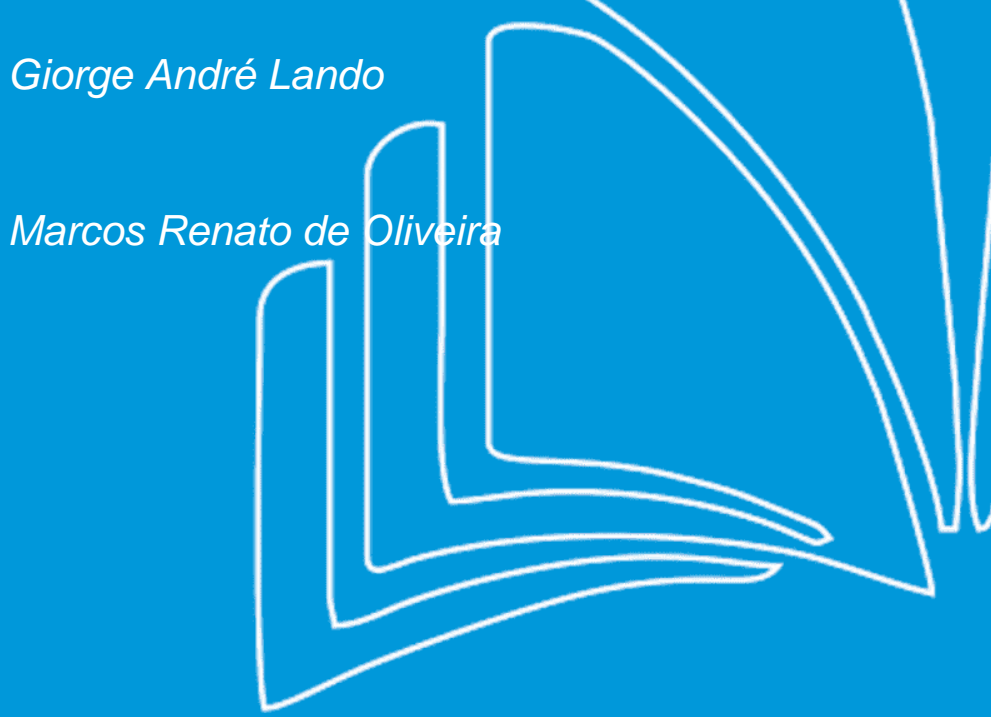

Universidade Federal de Santa Maria

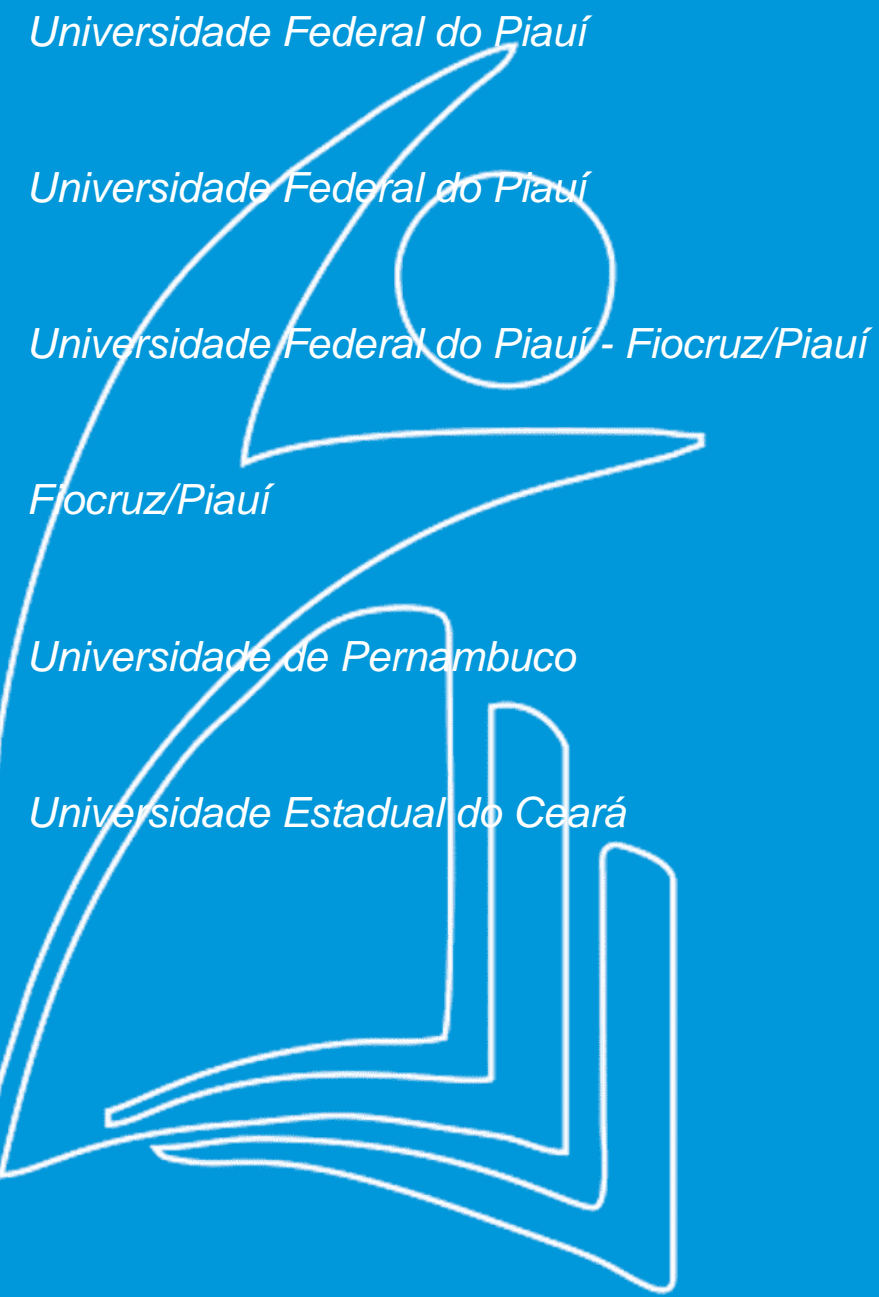


Resumo: O resultado do último processo eleitoral brasileiro de 2018 definiu, além de deputados, senadores e governadores, a escolha nas urnas do próximo Presidente da República. Para conquistar os eleitores, os candidatos utilizaram argumentos e estratégias variadas que refletissem suas ideias e iniciativas para a futura gestão, de modo a terem consequências diretas no comportamento eleitoral da população. Essas ações refletem em vários aspectos da sociedade, principalmente em camadas das minorias, como a de sujeitos LGBTQI+. Partindo deste princípio, surge-se, então, este estudo, com abordagem qualitativa, exploratória e de campo. Seu objetivo visou analisar o grau do sofrimento de sujeitos LGBTQI+ advindo do processo eleitoral brasileiro do ano de 2018. A pesquisa ouviu cinquenta participantes acima de dezoito anos do nordeste brasileiro, utilizando como recursos um questionário sociodemográfico e uma entrevista semiestruturada, sendo analisados por meio do método de Interpretação de Sentidos. Os resultados apontam uma disseminação maciça de fake news, como o kit gay e a ideologia de gênero, fortalecendo uma grande massa conservadora-religiosa, responsável pela eleição do, então, candidato Jair Bolsonaro. Como estratégias para lidarem com seus sentimentos diante deste cenário, os participantes utilizaram táticas diversas como a psicoterapia, religiosidades, atividades de cunho de lazer, além do afastamento de algumas relações interpessoais.

Palavras-chave: Eleições. LGBTQI+. Sofrimento. Ressignificações. 


\section{INTRODUÇÃO}

Dentre tantas aplicações, a política se traduz em uma importante ferramenta na vida dos sujeitos, uma vez que a mesma impacta na vida da população em diversos aspectos como a manutenção da saúde, educação, segurança e afins. Os modos que operam ações de cunho político advêm acerca de questões onde os personagens envolvidos buscam a melhor maneira de solucioná-las, ofertando o bem-estar Social (BAQUERO, 2010). De acordo com cada cultura, os processos de escolha de representantes, onde se atêm a responsabilidade de governar seja um município, um estado e, até mesmo, um país, são baseados no regime democrático.

Durante o processo histórico brasileiro, é possível observar diversas nuances que classificavam os modos de escolha desses governantes. Os sistemas foram avançando, trazendo diversas novidades atreladas, muitas vezes, à tecnologia, de modo a ofertar a maior confiabilidade daquele processo eleitoral (NICOLAU, 2012). Dessa forma, cabe a cada candidato traçar estratégias para alcançar o maior número possível de eleitores e, assim, garantir a sua elegibilidade. Vale ressaltar que todo esse sistema possui seu próprio conjunto de autofinanciamento, onde os partidos asseguram os melhores modos para que as atividades de campanha sejam realizadas (CAMPOS, 2009).

Dentro desse cenário, observa-se o paradigma da mudança, presente nos mais diversos discursos políticos. O que se evidencia é a busca pelas soluções das mazelas populacionais. Ouvindo as necessidades, hoje escancaradas em diversos locais, buscam-se produzir materiais onde apresentem aos eleitores ações que possam contribuir para a solução dessas adversidades. Os espaços tomados por cartazes, jingles e demais formas de expressão ganharam um fôlego a mais com a produção de divulgações de vídeos e imagens compartilhadas para milhões de pessoas em questão de segundos por meio da internet (CERVI; MASSUCHIN \& CARVALHO, 2016).

Os candidatos passam a buscar, por meio das suas propostas, iniciativas que visem a melhoria da sociedade como um todo. Observam-se, portanto, discursos e propostas que, alinhadas às visões de cada candidato, se tornam o cartão de visitas durante o período de processo eleitoral. As estratégias a serem utilizadas por cada um buscam não somente produzir uma aproximação do público eleitorado como também busca o reconhecimento de valores que também são compartilhados por cada eleitor (FONSECA, 2016).

Diante do exposto, é possível compreender que as campanhas políticas ofertam um caminho até lógico de compreensão, onde cada candidato busca, por meio do seu voto, não somente a solução para todas 
as questões pertinentes ao cargo pleiteado como também oferecem uma empatia pelo candidato, onde se mostram conceber das mesmas percepções. Uma questão maior se apresenta ao perceber que algum candidato produz falas e visões de mundo que representam discursos de ódio em relação a algum tipo de minoria. Mesmo com os direitos assegurados perante a Constituição, ainda existe uma parcela da população inviabilizada, colocada à margem da exclusão social, além de padecerem de violências e demais formas de vulnerabilidades, como a exemplo das mulheres, negros, pessoas com deficiência, indígenas e quilombolas, LGBTQI+ (Lésbicas, Gays, Bissexuais, Transgênero, Queer, Intersexuais) e afins (SCHÄFER; LEIVAS \& SANTOS, 2015).

As vivências no cenário político também podem ser reforçadoras de atitudes conservadoras e discriminatórias. Isso pode ser materializado por alguma proposta ou, até mesmo, por uma atitude e/ou comportamento de algum parlamentar. Essas iniciativas também colaboram para a reprodução do cunho segregacionista e violento por trás dessas ações. Mesmo em decorrência da miscigenação e a diversidade, é possível observar, no Brasil, ataques contra as minorias, ocasionando não apenas a negação dos direitos como também ameaças à própria existência (SAVI, 2015).

Analisando criticamente a sociedade brasileira, é possível perceber diversas barreiras sociais impostas a pessoas LGBTQI+. As mesmas são, na maioria dos casos, invisibilizadas, não possuindo acesso a direitos básicos e garantidos pela Constituição, como educação e saúde (CARDOSO \& FERRO, 2012). Outros aspectos podem auxiliar em mais sofrimento para essas minorias, a exemplo o período eleitoral de campanha em 2018. A busca pela escolha de um candidato, as opções disponíveis de voto, os discursos, ideias e ideologias declaradas são pontos importantes a serem pensados por essa população na hora de escolher seu voto. Mas, antes dessa decisão, esses mesmos pontos também podem ser fundamentais para o adoecimento psíquico de cada um.

É nesta perspectiva que esse estudo se apresenta, com o objetivo de analisar os aspectos psicológicos vivenciados por sujeitos LGBTQI+ advindos do processo eleitoral brasileiro do ano de 2018. O trabalho busca compreender essas nuances bem como suas características e como essa mesma população buscou mecanismos de promoção de autocuidado que foram utilizados diante desse cenário político.

\section{MÉTODO}

Trata-se de estudo qualitativo, exploratório e de campo realizado no município de Teresina, PI. Para a seleção dos participantes do estudo, foram elencados os seguintes critérios de participação: idade igual ou maior de 18 anos, dos mais variados gêneros, sujeitos que se declaram LGBTQI+ 
(independentemente de como se apresentam perante a sociedade), cursando ou com curso superior completo e pertencente a algum movimento social que contribui para as causas de questão de gênero e sexualidade. Foram excluídos deste estudo sujeitos que apresentaram um alto grau de sofrimento psíquico, apresentando dificuldades em responder os questionamentos apresentados. Esta exclusão reitera a necessidade dos posicionamentos éticos adotados neste estudo, uma vez que a temática poderia ocasionar maiores prejuízos à saúde e integridade dos sujeitos.

A cada participante foi entregue um Termo de Consentimento Livre e Esclarecido (TCLE). Participaram desta pesquisa 50 (cinquenta) pessoas que, de antemão, foram esclarecidas sobre todos os riscos e benefícios ofertados por este trabalho. O período de entrevistas ocorreu entre os meses de abril a setembro de 2019. Respeitando a resguarda e o anonimato das participações, os mesmos foram representados neste trabalho com um número especifico entre 1 a 50, sendo identificados como, por exemplo, "Entrevista 1". As entrevistas seguiram os protocolos éticos necessários, como a presença em um lugar tranquilo e sem interferências, respeitando os sujeitos, bem como o sigilo das informações.

Como procedimentos de coleta de dados foram utilizados: um questionário sociodemográfico, a fim de caracterizar o perfil dos participantes, e uma entrevista semiestruturada com perguntas definidas, com a finalidade de atingir os objetivos do estudo. Em ambas as técnicas foi utilizado um gravador de voz, com pré-autorização dos entrevistados, de modo a promover uma maior confiabilidade nos resultados apresentados.

Os dados foram analisados por meio da técnica de interpretação de sentidos. Essa modalidade é bastante utilizada, pois permite uma melhor compreensão do discurso do interlocutor, levando em consideração aspectos importantes da sua constituição, como o contexto histórico, e até onde o mesmo pretende levar sua fala (GOMES, 2016).

A primeira fase desse processo buscou organizar os dados, de modo a facilitar sua compreensão. Em seguida, foram feitas diversas leituras para compreender os pontos importantes, além de complementar com a literatura pertinente a qual abarca a temática do estudo. Posteriormente, houve a construção de categorias que quais permitem alocar as visões encontradas nos materiais e, por fim, uma análise e discussão sobre pontos importantes da pesquisa, estabelecendo uma conexão entre os sentidos descritos e o conhecimento (GOMES, 2016).

O estudo foi realizado com base na resolução n. 466/2012 do Conselho Nacional de Saúde, que regulamenta a pesquisa com seres humanos, garantindo a proteção dos envolvidos com base no 
respeito aos direitos e ética estabelecida pelos procedimentos científicos. O projeto foi aprovado sob o CAAE no 10100019.9 .0000 .5214$.

\section{RESULTADOS E DISCUSSÕES}

As pessoas que participaram do estudo consistem em uma ampla diversidade de gêneros, raças e vivências territoriais. Quando se trata dessa questão, observa-se uma grande quantidade de valores, ideias e personalidades, bem como as suas características sociodemográficas apresentadas nos instrumentos definidos para esta pesquisa.

As idades abarcaram as quantidades nos seguintes intervalos de tempo: vinte e quatro pessoas com idade entre 18-25 anos, quatorze com 26-33, cinco de 34-41, quatro com 42-49 e, por último, apenas três pessoas entre 50-57 anos. Majoritariamente, os participantes se declaravam como brancos, possuindo um menor número de negros e pardos. Os grupos de movimentos sociais pertencentes aos participantes variaram bastante entre, por exemplo, ligas acadêmicas de universidades a associações e coletivos da cidade de Teresina/PI.

O estudo contemplou pessoas LGBTQI+ ou, até mesmo, sem uma orientação sexual definida, identificando-se como cisgênero, transgênero ou travesti. Mesmo com a formação superior incompleta (em andamento), os participantes possuem diversas especialidades dentro das áreas das Ciências Humanas e Sociais, Exatas e da Saúde. Em específico, foi notório um grande percentual de sujeitos dos cursos de Psicologia e Serviço Social, já uma pequena parcela correspondia a formação de, por exemplo, Engenharia Civil.

A seguir, apresentam-se as três categorias definidas, compondo seus títulos por meio de trechos musicais que representam o conteúdo a ser apresentado e discutido. A divisão adveio da necessidade de melhor organização e compreensão dos dados apresentados. Para isto, foram observados a existência de três aspectos primordiais que apresentam a gênese deste estudo, bem como o seu objetivo. Para a classificação dos mesmos, foi pensado na utilização de trechos musicais que reiterassem o sentido atribuído a cada sessão. Trazer recursos, como sons, ofertam em uma ótima estratégia dentro da pesquisa qualitativa, uma vez que essas possibilidades enriquecem os materiais captados durante o estudo (BAUER, \& GASKELL, 2017). Esses elementos estão presentes apenas na nomeação das categorias. A primeira: "Eu entendi que era um sinal, aviso sobrenatural”, composição de Alexandre Lucas e Humberto Tavares, interpretação do grupo Jeito Moleque (Direitos Reservados a Universal Music Ltda - 2005). Já a segunda: “Me desesperei, meu mundo desabou”, autoria de Nety 
França e Stefhanny, tendo esta última como intérprete (Direitos Reservados a Stefhany Sousa - 2010). E, por fim, a terceira: "Quando a chuva passar, quando o tempo abrir, abra a janela!", criação de Ramón Cruz e musicista Ivete Sangalo (Direitos Reservados a Universal Music Ltda - 2005).

\section{EU ENTENDI QUE ERA UM SINAL, AVISO SOBRENATURAL (ALEXANDRE LUCAS/ HUMBERTO}

\section{TAVARES - COMPÔS.)}

O trecho dessa canção reitera diversos alertas que culminaram em uma reação de espanto e surpresa do eu lírico. Dentro da subjetividade humana, as emoções e sentimentos são processos psicológicos básicos que não só fomentam em estratégias de sobrevivência como também promove um grau de humanização entre os seres por meio da afetividade. É de suma importância permitir o desenvolvimento desses aspectos, pois eles estão correlacionados a experiências de vivências, dando contexto à situação, revelando-se como um potencial necessário para a maturação das estruturas cognitivas, como a de aprendizagem (BATISTA, 2019).

Analisando essas questões, os entrevistados relataram nesse quesito as principais notícias vinculadas ao período eleitoral de 2018 , as quais promoveram algum tipo de sofrimento, uma vez que o sistema psicológico humano, assim como outras áreas do corpo humano, também adoece e produzem efeitos negativos diversos na saúde mental (CECCARELLI, 2005).

A produção de fake news relacionadas ao público LGBTQI+, sem dúvidas, se tornou o ponto mais dialogado entre os participantes. Durante a campanha, houve boatos circulados nas redes sociais sobre notícias e propostas de governo atribuídas à influência de crianças e adolescentes a se tornarem homossexuais, assim como medidas para combater essas mesmas propostas. A questão logo se difundiu pelo país, sendo atribuída a denominação de kit gay, que seria disponibilizado em escolas.

É nesse momento que se escancara o preconceito e a discriminação. Fontes, mesmo que errôneas como essas, contribuíram para o fortalecimento dos adeptos ao conservadorismo religioso, onde é passível de crime, aos olhos de determinada crença, práticas comuns que envolvem a sexualidade humana (MARANHÃO Fo, COELHO, \& DIAS, 2018). Nesse sentido, surgem-se reflexões sobre o quanto o ser biológico ainda interfere nas relações humanas. O desenho geneticamente construído ao longo da maternidade deveria ser a decisão final de como deve ser uma pessoa? É a partir da concepção de uma vida que discursos e atitudes colaboram para a determinação social de como aquele sujeito deverá ser. Independente da construção de aspectos importantes como a sua personalidade, é acrescido à sua pessoa uma postura deliberadamente definitiva (BUTLER, 2003). 
É que a gente já esperava porque, como era um governo conservador, o que ele tentou fazer, o que ele conseguiu por meio da fake news além de se eleger, mostrar que são as pessoas conservadoras e como elas vão agir com a gente partir de agora. (Entrevista 24).

“... é um reflexo da sociedade em geral, os preconceitos que antes eram todos velados, eles se externaram bastante." (Entrevista 15).

"A gente sabe que o preconceito existe, mas quando vem de algo que supostamente tem muito poder, como presidente, eu me senti bem surpresa, eu me senti mal porque, às vezes não consigo sentir revolta, eu sinto mesmo é tristeza, mesmo." (Entrevista 5).

Reflexo esse presente na obra de Foucault (1998), onde ele relata sobre os passos dados pela sociedade em relação a pontos como gênero e sexualidade. A grande parcela de discriminação e situações vexatórias são heranças de séculos, onde comportamentos homossexuais eram proibidos e considerados pecaminosos. O conhecimento corporal ou demais formas que dessem algum tipo de prazer também eram condenadas. Desse modo, a sociedade passou a ocultar essa faceta humana.

Apesar da caracterização de tempos modernos, as sociedades ainda consideram determinados assuntos como tabus, que resistem a debates e soluções. Ainda é possível encontrar uma educação conservadora, onde não há espaço para o respeito às diferenças e à subjetividade humana. Para isso, foram criadas regras sociais, justificadas por diversos aspectos e, até mesmo, teóricos. Nesse sentido, mesmo sendo considerada uma expressão individual, torna-se um grande desafio vivenciar sua sexualidade de maneira singular sem que isso cause desconfortos e conflitos em terceiros, mesmo que esses não possuam relevância ou consequências diante dos atos de cada ser.

Com o processo de empoderamento, a população LGBTQI+ passou a se articular provocando movimentos de reivindicações de direitos. O armário, de fato, já estava pequeno demais. Ao longo dos anos, no Brasil e no mundo, podem-se observar políticas e programas que defendem e protegem direitos da população LGBTQI+, bem como combatem a atitudes discriminatórias como a homofobia (MELO; BRITO \& MAROJA, 2012). Já, na contramão dessa caminhada, discursos segregacionistas, intolerantes e dotados de agressividade são lançados nos mais diversos meios de propagação como uma reafirmação de um posicionamento que deve ser predominante (SESSA \& TOMAZI, 2018).

“... foi justamente essa fala do presidente eleito, que ter filho gay é por falta de porrada. Isso me feriu bastante, sabe?" (Entrevista 30).

“...eu me lembro de um vídeo que um cara, ele postou a torcida que parece que é a do Cruzeiro numa estação de trem, falando Bolsonaro vai matar viado, é que teve várias situações assim, né." (Entrevista 4).

O uso de fake news pela disputa presidencial deixa um país sem limites diante de tantas notícias vinculadas por minuto. Os debates se tornam praticamente inválidos. A percepção de que aquela fonte 
traduz toda a verdade necessária é confirmada diante da opinião de pessoas significativas (FRIAS FILHO, 2018). Independente dos motivos da inserção desse fenômeno no processo eleitoral brasileiro, é inegável sua presença.

Se antes esse fenômeno era desconhecido, pelo menos no Brasil, agora é bastante notória a sua presença em diversos meios, sejam eles acadêmicos ou não, levantando pautas diante das suas consequências no dia a dia das pessoas.

“... nessas eleições passadas, eu achava um pouco distante a fake news... e a gente tinha isso bem de perto porque foi uma campanha baseada em fake news..." (Entrevista 6).

“... as pessoas usavam muito essas fake news justamente para validar esse discurso e se encarregavam disso de maneira convicta, mas tá aqui no Whatsapp, você ficava meio que tentando procurar provas." (Entrevista 7).

“... então, eu sempre pesquisava e, na grande maioria das vezes, eram fake news, acho que por parte do outro lado, tentando fazer com que essa classe ficasse pra baixo de certa forma e disseminar o ódio mesmo." (Entrevista 1).

As fake news se tornaram as protagonistas do século XXI. Com a recém-chegada de novas tecnologias de informação, assim como o poder de acesso a elas, ficou mais evidente o rápido recebimento de infinitas mensagens até os aparelhos eletrônicos das pessoas. É nesse momento que essas notícias falsas chegam à população e ganham rapidamente milhões de admiradores por minuto. O ciclo não termina por aí, pois, ao mesmo tempo em que elas ganham muito convencimento, há também uma nova leva de milhões de pessoas que repassam a mensagem adiante. É um ciclo veloz e fatal (DELMANAZO \& VALENTE, 2018).

Falando nesse aspecto, essas trocas de informações falsas produzem uma determinada discussão no campo social. Nesse sentido, é possível que as ideias sejam debatidas e proporcionem a criação de "lados", onde cada um opina sobre a determinada notícia.

“... teve também um momento no grupo da família que começaram a discutir sobre seus posicionamentos em relação a isso, do Bolsonaro, minha mãe não ligada tanto essas questões, mas eu estava sozinha dentro do grupo..." (Entrevista 5).

“... a gente percebeu que ficamos meio encurraladas, porque o discurso dele, ele espalha para milhares de pessoas que já tinha um certo ódio por dentro em si e acaba despertando... muita gente passou a despertar esse ódio..." (Entrevista 6).

À medida que as pessoas se posicionam dentro do campo das fake News, há uma autodeclaração acerca das suas concepções políticas. Na grande maioria das vezes, o rompimento entre os ideais e os valores de pessoas que receberam a mesma manchete é quase que inevitável (MIGUEL, 2019). 
“... era como se a gente tivesse lados e o outro lado que estava contrário a do presidente sofria não só pela posição política, mas por todos os valores." (Entrevista 19).

“... discussões tipo, no ônibus, na parada e na rua, na família de pessoas que defendem representantes que defendem esse tipo de posicionamento." (Entrevista 9).

Surgem, então, conflitos que antes não existiam, liberando opiniões e crenças desconhecidas pelo geral. Analisando esta questão, podem-se observar duas nuances interessantes. A primeira diz respeito ao próprio conflito em si, fazendo as pessoas se tornarem opositoras de ideias. Já a segunda aparenta trazer um acalento ao ponto anterior, uma vez que dentro dessa questão é possível achar pares iguais de pensamentos, pois onde se perde um amigo, se conquista um aliado.

É necessário se ater a mais questões envolvendo esse rápido e longo processo. Qual a finalidade de uma fake news? Da sua concepção até as suas consequências também demonstra ser um caminho desconhecido, entretanto, nas sociedades atuais, o seu uso é frequente, de modo a atrair uma parcela da população a respeito de algo ou alguém. Nesse sentido, as fake news se tornam convenientes, pois elas representam em uma importante vantagem dentro de um negócio. Enganam-se quem pensa em sua utilização apenas nas organizações. Também se pode esperar sua participação nos sistemas eleitorais democráticos (BRAGA, 2018).

“... elas, apesar de fakes, entraram na mente das pessoas e isso foi terrível. E aí assim pensando: "Meu Deus!"” (Entrevista 12).

“... naquele momento eram notícias que saiam todo dia, um bombardeio de informações e informações deturpadas." (Entrevista 38).

“... e ele ganhou com essa história de kit gay, que não existia, onde foi um dos principais mecanismos de que ele usou, como massa de manobra para pegar aquelas pessoas que estava naquele momento se sentindo acuado, por vendo tantos direitos sendo garantido pela população LGBT." (Entrevista 13).

Os resultados apontaram que grande parte da estratégia de eleição do, até então, candidato à presidência Jair Bolsonaro (até então, pertencente ao partido PSL) foi utilizada de modo a angariar o apoio de conservadores e radicais de extrema direita. As massivas notícias beneficiavam seu discurso político baseado em preceitos religiosos, pois defendia ferozmente valores importantes como a família de cunho heterossexual, atribuindo o mal-estar social à perda de fatores como esses.

“... na verdade foram as fake news que conseguiram ser o grande foco desse processo de eleição, não é à toa que o presidente eleito gastou milhões nesse campo, disseminando essas e muitas outras fake news em vários campos, atacando diversas pessoas, diversos movimentos sociais, ideias progressistas, enfim." (Entrevista 50). 
"Eu fiquei bastante... assim... triste, porque assim é nessas eleições passado, eu achava pouco distante a fake news, então a gente, aqui brasileiro, tinha isso bem de perto." (Entrevista 6).

Esses movimentos virtuais contribuem para ações no campo social. Uma notícia que representa um discurso de ódio relacionado a uma minoria oferece o suporte necessário para tornar comportamentos agressivos reais. É o que contou a realidade de alguns participantes.

“... os comentários nas redes sociais: "Ah... Quando Bolsonaro ganhar, essas bichas vão apanhar", "ah... quando Bolsonaro ganhar, vocês não vão mais existir"". (Entrevista 3).

“... e aconteceu durantes as eleições... existiu alguns casos que teve aqui em Teresina mesmo. O rapaz que foi espancado na rua que estava com a camisa vermelha... aquele rolê todo e assim, para mim, foi mais questão da imposição de medo com bases nas redes sociais." (Entrevista 23).

Já é possível afirmar cientificamente o papel que essas informações promovem em processos eleitorais (FERREIRA, 2018). Além disso, é notório o grande número de pessoas que são atingidas por canais como as redes sociais, dificultando o processo de separação daquilo que é, de fato, verídico ou não. Entretanto, outros meios de comunicação acadêmica já abrem espaço para barrarem essas iniciativas. Também é possível observar a criação de programas que visam desenvolver o senso crítico dos indivíduos como forma de combate a essa propagação desenfreada (BRITES, AMARAL, \& CATARINO, 2018).

\section{ME DESESPEREI, MEU MUNDO DESABOU (NETY FRANÇA/STEFHANNY - COMPÔS.)}

O que acontece quando o que se teme se concretiza? As probabilidades de reações são infinitas, mas é esperado algumas bem conhecidas e comuns. Como o próprio título desta categoria, as respostas encontradas pelas (os) entrevistadas (os) acarretam em emoções fortes e intensas atreladas a experiências ruins. Emoções e sentimentos são características fundamentais para a existência humana. Em algum grau de intensidade elas são vivenciadas, produzindo as mais diversas sensações e consequências no organismo, como a alteração na consciência (DAMÁSIO, 2015).

Pensando nessa perspectiva, o estudo apresenta as características emocionais vivenciadas pelos sujeitos LGBTQI+ com a vinculação não só das notícias falsas, discutidas no tópico anterior, como também em relação à campanha eleitoral que deu vitória ao candidato Jair Bolsonaro (até então, pertencente ao partido PSL). 
"Eu acordei e me lembro que fiquei tão abalado nos dias posteriores às eleições que eu não estava conseguindo dormir." (Entrevista 4).

"A gente ficou e já tinha medo, e agora o nosso medo se potencializou por meio de um presidente que é preconceituoso." (Entrevista 41).

O medo, a angústia e o temor foram emoções bastante presentes nos relatos. Ser LGBTQI+ em um país onde se veiculava notícias que pregavam formas de exterminação desse grupo desperta uma onda de insegurança e pânico a quem é destinado o ódio gratuito. Essas reações se apresentam como uma possibilidade, uma vez que a raiva pode ser descarregada em ações que visem atingir seu objetivo (FRAZZETO, 2014). Portanto, é acreditável esperar e temer que esses grupos sejam atingidos por grupos formadores de discursos de ódio.

Dessa forma, o medo funciona como uma resposta fisiológica natural, capaz de detectar onde podem ocorrer situações que ofertam risco à nossa segurança. Isso passou a ser evidenciado com uma força maior para os(as) entrevistados(as), já que as eleições se tornam um aspecto estressor e ameaçador, ligado a estigmas, preconceitos e discriminações diante da possibilidade de vivenciar sua sexualidade de maneira singular (CLARK \& BECK, 2012).

"O sofrimento que eu mais senti próximo de mim (durante as eleições) foi a questão do medo mesmo, quase um pânico de andar na rua, de ser o que eu sou." (Entrevista 32).

Além disso, afloraram outros sentimentos perante a coleta dos resultados. A descrição do desânimo, ocasionado pela angustia, também trouxe muito destaque nas falas. Com o resultado final das eleições, muitos questionaram e duvidaram de como seria o futuro desses LGBTQI+ no Brasil. Como continuar (r)existindo em um país que, tecnicamente, odeia uma das constituições desses seres? Reflexo disso é que o candidato Jair Bolsonaro teve um número expressivo de 57.797.847, correspondente a 55,13\% dos votos (MAZUI, 2018).

"Eu em sentir fraco e impotente, mas foi porque por questão de medo, muito medo." (Entrevista 20).

Os medos e receios abordados pelos indivíduos foram formados por base de diversas crenças e valores conservadores adotados pelo candidato vencedor das eleições de 2018. Dessa maneira, não é de se estranhar a percepção de um futuro governo que também ande de mãos dadas com esses ideais, o que os levam a crer em uma cadeia onde os mais fracos não terão vez e voz na construção desse país ao longo dos quatros próximos anos. Essas pessoas fazem parte, portanto, de uma minoria que temem mais ainda a exclusão, uma vez que essa artimanha é utilizada ao longo de séculos de solidão e 
ostracismo (PESSOA et al., 2020). Sem dúvidas, é possível inferir sobre as consequências dessas percepções, onde há mais efeitos do que se imagina.

O psicólogo Henri Wallon aborda em suas obras a importância da afetividade na construção humana. Os episódios vividos por cada um estão atrelados a uma carga emocional que permite as mais diversas reações. A partir delas, os sujeitos encontram novas formas de se relacionar com o mundo e lidar com os acontecimentos mais adversos (TASSONI \& LEITE, 2013). Além disso, os sujeitos passaram a lidar com outras consequências da intolerância. A mesma ganhou destaques além do físico e da existência humana, mas passou a prejudicar a saúde mental dos envolvidos.

Analisando esse movimento, é possível compreender que os aspectos emocionais dos participantes também afloraram em decorrência do período eleitoral. Os dados apontam para um adoecimento relacionado ao cenário que foi construído, bem como o pavor das suas consequências futuras. Desse modo, encontram-se fragilidades nas subjetividades desses indivíduos, colocando em risco não somente a sua saúde mental.

"Eu vi uma amiga que teve crises por conta desse medo, desse receio que ela teve. Em mim, gerou mais foi preocupação e desânimo às vezes." (Entrevista 46).

A psicossomática, ramo que se alimenta da Psicologia e da Medicina, oferece arcabouços que facilitam o entendimento dessa situação. Essa própria ramificação busca entender os mecanismos que envolvem o adoecer e o sistema psíquico. Os avanços dos tempos permitiram a entrada de saberes multidisciplinares que corroboram com a origem de possíveis doenças correlacionadas ao sofrimento psicológico (MELLO FILHO \& BURD, 2010).

Essas acepções os convidam a pensarem no sofrimento além dos pontos da biologia humana. 0 adoecimento psíquico tem ganhado grandes destaques ao longo do tempo, onde se percebeu que suas consequências são tão danosas quanto as enfermidades que atingem o corpo físico humano.

Condições como as relatadas nesse tópico implicam no cansaço do indivíduo com a realidade. Aspectos motivacionais também podem ser afetados, modificando os projetos pessoais e profissionais de futuro. Entretanto, sem surpresa alguma, a saúde mental desses indivíduos acaba sendo a mais prejudicada nesse infame processo. Como cada um lidou com isso? São as próximas considerações abordadas a seguir. 
QUANDO A CHUVA PASSAR, QUANDO O TEMPO ABRIR, ABRA A JANELA (RAMÓN CRUZ COMPÔS.)

Momentos de adversidades serão comuns a todos os seres humanos, já as razões atreladas a esse movimento são particulares de cada pessoa. Como superar uma dificuldade? Quais os caminhos são passíveis para a resolução de conflitos? Ao que aparenta, parece haver muitas dúvidas e poucas soluções. A formação humana permite, desde a pequena idade, a produção de estruturas cognitivas responsáveis por desenvolver ideias e atitudes facilitadoras na resolução de conflitos (LEME, 2004).

É bem notório, por meio das discussões anteriores deste trabalho, que o período eleitoral brasileiro de 2018 apresentou fatores que contribuíram para o adoecimento da saúde mental do segmento de pessoas LGBTQI+. Entretanto, o ponto em questão, assim como no trecho da música que o identifica, apresenta as soluções mais encontradas diante da crise instaurada pela campanha e vitória do candidato Jair Bolsonaro. A busca pela psicoterapia serviu como maior instrumento de ajuda entre as entrevistas.

"É, como já te disse, a questão de eu já fazer o tratamento com a psicóloga." (Entrevista 1).

A psicoterapia revolucionou o mundo como um novo método de tratamento daquelas doenças diagnosticadas como causas psíquicas. Ganhando destaque dos seus primórdios até os dias atuais, essa prática da Psicologia busca ofertar, por meio de vários preceitos e dinâmicas, um local apropriado para o estabelecimento da psique humana. Das primeiras experiências por Freud até as novas ramificações da ciência da subjetividade, buscou-se ofertar o apoio necessário para as mais diversas demandas que chegam até os consultórios clínicos (JUNG, 2011).

O falar se torna um forte recurso terapêutico. Deve ser por isso que os resultados evidenciaram uma grande procura pela clínica da Psicologia. Encontrar um ambiente onde é possível falar de suas angústias e como administrá-las se tornou necessário na sociedade atual. Assim sendo, as dores e perdas criadas e reiteradas durante as eleições de 2018 estabeleceram-se na queixa principal de grande parte de grupos de minorias que tiveram acesso a essa possibilidade, afinal de contas, por meio da fala é concebível dar novos sentidos àquilo que se apresenta sem sentido algum ao indivíduo (FOCHESATTO, 2011).

Ganhando espaços em ambientes mais acessíveis, os serviços de Psicologia espalhados pelo país levam o apoio e suporte necessários diante do quadro de um sofrimento psíquico. Assim sendo, os sujeitos 
encontram um espaço de acolhimento à sua dor, utilizando da sua própria forma de expressão o mecanismo necessário para o enfrentamento do que lhe traz ao setting terapêutico.

Outros dispositivos também apareceram no hall das estratégias de fuga de mazelas psicológicas. A crença em uma religião e/ou espiritualidade fortaleceu os incluídos nesse movimento, pois buscar uma crença oferece o reforço necessário ausente diante de sinais negativos ofertados pelo que é desconhecido (AQUINO et al., 2009).

O que eu busquei foi a religião em si, a Umbanda em si, que me fez ter força, já que um dos lemas dela é força e resistência, e essa foi a estratégia que deu pra mim." (Entrevista 32).

"Tô dizendo que a arma que eu usei pra manter a minha saúde mental, pelo menos $80 \%$ sã (risos), foi me apegar a Deus." (Entrevista 41).

Existentes ao longo de vários séculos, as práticas alternativas e integrativas passaram a compor no Sistema Único de Saúde (SUS) como uma forma de benefício de recuperação do usuário dentro do processo saúde-doença (BRASIL, 2006). Esses exemplos também foram acionados entre os(as) participantes da pesquisa, dado que suas metodologias produzem bem-estar não apenas físico e psicológico como também o aumento na qualidade de vida (AZEVEDO et al., 2015).

“... eu tento fazer meditação." (Entrevista 16)

“... faço outras práticas como meditação." (Entrevista 43)

“... o que eu gastei de dinheiro comprando vela, acendendo vela pra tudo enquanto." (Entrevista 3).

Outro aspecto bastante considerável e de grande interesse foram as articulações feitas. O bem-estar veio de apoios mútuos entre iguais, onde os mesmos acreditam e levantam bandeiras em idênticos aspectos com a reafirmação de estudos de modo a assegurar, além de uma forma de resistência, o engajamento de mais pessoas para a causa por meio da conscientização social e virtual.

\footnotetext{
"Me fortalecer politicamente com os meus amigos, com os grupos que eu tinha organizado e de também manter vínculos com as pessoas que são engajadas no assunto." (Entrevista 35).

"Buscar acolhimento e posicionamento de resistência, ações de resistência contra as políticas de morte do governo federal." (Entrevista 33).

"Criar movimentos em rede, movimentos compartilhados de afeto, de cuidado, de cuidado de si e do outro, foi um momento que eu fui me juntar com as minhas manas e não necessariamente minhas amigas, ou não, mas com pessoas que você via que tinha pensamentos ideológicos parecidos com o seu." (Entrevista 28).
}

Considerado um marco na saúde mental, desenvolver ações de ajuda mútua produz o fortalecimento dos membros em prol de uma só causa: a sua recuperação por meio de caminhos a serem percorridos 
e traçados de forma conjunta (RIBEIRO et al., 2017). Traduzindo de maneira comum a aplicação da frase "ninguém solta a mão de ninguém", inclusive um marco viral após o resultado das eleições de 2018, não teria espaço melhor para seu uso.

É nesse movimento de forças que grupos, coletivos e movimentos surgem, além do fortalecimento dos já existentes. Situações como essas, onde é possível vislumbrar uma política no país que fere não só a minha existência como a manutenção de diversos direitos humanos, causam uma forte articulação popular. São práticas como essas que engajam o fomento de políticas públicas, fazendo os principais interessados parte importante desse processo.

Todavia, uma grande porcentagem preferiu montar outra estratégia: a blindagem. Essa ação visou excluir, em alguns casos permanentemente, relações, sejam elas pessoais ou virtuais, com pessoas que demonstravam ser a favor do candidato Jair Bolsonaro. O afastamento dessas formas de convívio passou a ser um catalisador diante do resultado obtido nas ruas. Buscar não ver ou discutir situações, falas ou propostas governamentais trouxeram o alívio tão almejado.

\footnotetext{
"Ah, me afastar de pessoas tóxicas, de pessoas que se debandearam e que já sempre foram fascistas e estavam lá do outro lado, eu excluí todas essas pessoas das minhas redes sociais, eu não quero. Óbvio que não podemos evitar certa convivência e contato com essas pessoas, mas eu, quando eu posso, né?!" (Entrevista 29).

"É aquele negócio que a gente se fala: aquilo que não te faz bem, é melhor você se afastar, né?" (Entrevista 21).
}

O julgamento de cada um busca analisar dentro daquela relação o que se pode tornar reforçador ou prejudicial. Tende-se a colocar numa balança o conflito para a busca de uma solução. Nesse momento, surge o abandono daquele laço, daquele afeto, onde, muitas vezes, há razões mais que sociais que transcendem os sujeitos, entretanto, a racionalidade escancara o que é real e o imaginário dessa ligação. Já não há mais o que negar (BAUMAN, 2004). Mas será que todos conseguiram encontrar uma saída?

\footnotetext{
"Ainda não tenho (uma estratégia). O medo predomina. Até não ser resolvida essa situação, o medo continua e ele ainda é mais forte outrora." (Entrevista 31).
}

\section{CONSIDERAÇÕES FINAIS}

A pesquisa permite o conhecimento de mundo no qual não temos acesso, em que se busca dar voz aos sujeitos e possibilitar a compreensão daquele problema pelo seu ponto vista, pela sua visão. 0 final deste estudo não poderia ser diferente. Ele propiciou lugar de fala a indivíduos que 
historicamente são segregados e mantidos à margem da sociedade. Um grupo de pessoas às quais seus direitos são negados, inclusive o de existir.

Suas lutas e ações resistem ao longo do tempo mobilizando novos atores para inserção da resistência. Claro que um grupo como esse também é marcado por fatos sociais que existem nas sociedades e garantem o seu funcionamento. Um exemplo discutido neste trabalho foi o episódio das eleições brasileiras do ano de 2018. A busca por compreender como essa cena influenciou a vida da população LGBTQI+ foi o ponto de partida para a construção deste e de outros materiais científicos.

Se antes as eleições pareciam, pelo menos de longe, um ponto inofensivo, se tornou, em questão de pouco tempo, uma grande ameaça. Esses indivíduos viram em campanhas presidenciais - uma específica (do candidato Jair Bolsonaro) - um ultimato, pois seria agora que o destino, o julgamento final aconteceria. Mas pode haver razão para todo este temor? Fake news ganharam o país do Oiapoque ao Chuí, articulando não só uma rede de mentiras a benefício do candidato como também a união de conservadores políticos religiosos. Quem diria que haveria espaço para confluência dentro da intolerância.

Esse ponto trouxe muito adoecimento e promoveu dores profundas que só serão sentidas por determinados grupos da sociedade. Cada ideia, estratégia e ação presentes na campanha eleitoral do, até então, candidato Jair Bolsonaro reiterava a negação dessa população de viver genuinamente a sua identidade. Passada as tristezas, medos e anseios, a solução foi buscar ajuda para enfrentar esse novo e imenso desafio. Tudo vale nesse momento. Buscar psicoterapia, crença em Alá, Maomé, Jeová? Pode ser qualquer um que, finalmente, consiga restabelecer a paz individual. Entretanto, algo bonito de se ver é que, mesmo ao final do jogo, a equipe permanece unida, forte e buscando a resistência e a força necessária para continuar jogando. Afinal de contas, a luta não acabou, não é mesmo? 


\section{REFERÊNCIAS}

AQUINO, T. A. A. et al. Actitud religiosa y sentido de la vida: un estudio correlativo. Psicologia: Ciência e profissão, v. 29, n. 2, p. 228-243, 2009.

AZEVEDO, A. C. B. et al. Benefícios das Práticas Alternativas Integrativas e Complementares na Qualidade de Vida da Pessoa Idosa. Acta de Ciências e Saúde, v. 1, n. 1, p. 1-19, 2016.

BAQUERO, M. Cultura política e processo eleitoral no Brasil: o que há de novo. EM DEBATE EM DEBATE, 2010.

BATISTA, J. B. O desenvolvimento de emoções e sentimentos na infância como fundamento psicológico da educação escolar (Dissertação de Mestrado). Universidade Estadual Paulista - UNESP, Araraquara, 2019.

BAUER, M. W.; GASKELL, G. Pesquisa qualitativa com texto, imagem e som: um manual prático. Editora Vozes Limitada, 2017.

BAUMAN, Z. Amor líquido: sobre a fragilidade dos laços humanos. Editora Schwarcz-Companhia das Letras, 2004.

BUTLER, J. Questões de gênero. Problemas de gênero: feminismo e subversão da identidade. Tradução de Renato Aguiar. Rio de Janeiro: Civilização Brasileira, 2003.

BRAGA, R. M. D. C. A indústria das fake news e o discurso de ódio. In: PEREIRA, R. V. (Org.). Direitos políticos, liberdade de expressão e discurso de ódio: volume I. Belo Horizonte: Instituto para o Desenvolvimento Democrático, 2018.

BRASIL. Ministério da Saúde. Secretaria de Atenção à Saúde. Departamento de Atenção Básica. Política Nacional de Práticas Integrativas e Complementares no SUS - PNPIC-SUS. - Brasília, 2006.

BRITES, M. J.; AMARAL, I. \& CATARINO, F. A era das "fake news": o digital storytelling como promotor do pensamento crítico. Journal of Digital Media \& Interaction, n. 1, v. 1, pp. 85-98, 2018.

CARDOSO, M. R.; FERRO, L. F. Salud y población LGBT: demandas y especificidades en cuestión. Psicologia: ciência e profissão, v. 32, n. 3, p. 552-563, 2012.

CAMPOS, M. M. Democracia, partidos e eleições: os custos do sistema partidário-eleitoral no Brasil. 238 f. (Tese de Doutorado). Universidade Federal de Minas Gerais, Belo Horizonte, 2009.

CLARK, D. A., \& BECK, A. T. Vencendo a ansiedade e a preocupação com a terapia cognitivocomportamental. Porto Alegre: Artmed, 2012.

CECCARELLI, P. O sofrimento psíquico na perspectiva da psicopatologia fundamental. Psicologia em estudo, v. 10, p. 471-477, 2005.

CERVI, E. U.; MASSUCHIN, M. G.; CARVALHO, F. D. Internet e eleições no Brasil. Curitiba: CPOP, 2016.

CRUZ, R. Quando a chuva passar. [Gravado por Ivete Sangalo] In: As Super Novas - Vol. 01. [Disco], Universal Music Ltda. (Gravado em 2005), 2005. 
DAMÁSIO, A. O mistério da consciência: do corpo e das emoções ao conhecimento de si. Editora Companhia das Letras, 2015.

DELMAZO, C.; VALENTE, J. C. L. Fake news nas redes sociais online: propagação e reações à desinformação em busca de cliques. Media \& Jornalismo, v. 18, n. 32, p. 155-169, 2018.

FERREIRA, R. R. Rede de mentiras: a propagação de fake news na pré-campanha presidencial brasileira. Observatorio (OBS*), v. 12, n. 5, 2018.

FOCHESATTO, W. P. F. A cura pela fala. Estudos de psicanálise, n. 36, p. 165-171, 2011.

FONSECA, M. E. V. A Política e o Espetáculo: OS efeitos do espetáculo no processo eleitoral brasileiro. 19 f. (Monografia de Graduação). Centro Universitário do Sul de Minas UNIS-MG, Minas Gerais, 2016.

FOUCAULT, M. Microfísica do poder. 13a Edição. Rio de Janeiro, RJ: Graal, 1998.

FRANÇA, N., SOUSA, S. (2010). Meu Mundo Desabou [Gravado por Stefhany]. In: Rei do Universo, Vol. 3. [Disco], Stefhany Sousa. (Gravado em 2010), 2010.

FRAZZETTO, G. Alegria, culpa, raiva, amor: O que a neurociência explica e não explica sobre nossas emoções e como lidar com elas. Agir Editora, 2014.

FRIAS FILHO, O. O que é falso sobre fake news. Revista Usp, n. 116, p. 39-44, 2018.

GOMES, R. A análise de dados em pesquisa qualitativa. In: MINAYO, M. C. Pesquisa social: teoria e método. - Petrópolis, RJ: Editora Vozes, 2016.

JUNG, C. G. A prática da psicoterapia. Editora Vozes Limitada, 2011

LEME, M. I. S. Resolução de conflitos interpessoais: interações entre cognição e afetividade na cultura. Psicologia: Reflexão e Crítica, v. 17, p. 367-380, 2004.

LUCAS, A., \& TAVARES, H. Sobrenatural [Gravado por Jeito Moleque]. In: Me Faz Feliz (Ao Vivo) [Disco], Universal Music Ltda. (Gravado em 2005), 2005.

MARANHÃO FILHO, E. M. A.; COELHO, F. M. F.; DIAS, T. B. Fake news acima de tudo, fake news acima de todos": Bolsonaro e o "kit gay", "ideologia de gênero" e fim da "família tradicional. Correlatio, v. 17, n. 2, p. 65-90, 2018.

MAZUI, G. Jair Bolsonaro é eleito presidente e interrompe série de vitórias do PT. G1 - O Portal de notícias da Globo. Brasília, 2018.

Disponível em:<https://g1.globo.com/politica/eleicoes/2018/noticia/2018/10/28/jair-bolsonaro-eeleito-presidente-e-interrompe-serie-de-vitorias-do-pt.ghtml>.

MELLO FILHO, J., \& MIRIAM, B. U. R. D. Psicossomática hoje. Artmed Editora, 2010.

MELLO, L.; BRITO, W.; MAROJA, D. Políticas públicas para a população LGBT no Brasil: notas sobre alcances e possibilidades. Cadernos pagu, p. 403-429, 2012. 
MIGUEL, L. F. Jornalismo, polarização política e a querela das fake news. Estudos em Jornalismo e Mídia, v. 16, n. 2, p. 46-58, 2019.

NICOLAU, J. Eleições no Brasil: do Império aos dias atuais. Editora Schwarcz-Companhia das Letras, 2012.

PESSOA, B. G. F. et al. A mão do carrasco: o impacto na saúde mental da população LGBT+ após o período eleitoral de 2018 no Brasil. Research, Society and Development, v. 9, n. 6, p. e193963168e193963168, 2020.

RIBEIRO, Ó. et al. Grupos de Ajuda Mútua para Cuidadores: Informais de pessoas com demência: no sentido de um helping ethos comunitário. Physis: Revista de Saúde Coletiva, v. 27, p. 397-413, 2017.

SAVI, R. M. Os impactos do discurso de ódio na saúde mental de ativistas dos direitos humanos. $46 \mathrm{f}$. (Monografia de Graduação). CENTRO UNIVERSITÁRIO DE BRASÍLIA - UniCEUB, Brasília, 2015.

SCHÄFER, G.; LEIVAS, P. G. C.; SANTOS, R. H. Discurso de ódio: da abordagem conceitual ao discurso parlamentar. Revista de Informação Legislativa-RIL. Brasília, v. 52, p. 143-158, 2015.

SESSA, A; T.OMAZI, M. M. O INTERDISCURSO VIOLENTO NAS NOTÍCIAS DO UNIVERSO LGBT. PERcursOS Linguísticos, v. 8, n. 20, p. 88-104, 2018.

TASSONI, E. C. M.; LEITE, S. A. S. Afetividade no processo de ensino-aprendizagem: as contribuições da teoria walloniana. Educação, v. 36, n. 2, p. 262-271, 2013. 